\title{
Revision of Chassalia (Rubiaceae-Rubioideae-Palicoureeae) in Borneo, with 14 new species
}

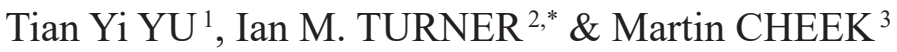 \\ ${ }^{1,3}$ Herbarium, Royal Botanic Gardens, Kew, Richmond, Surrey TW9 3AE, UK. \\ ${ }^{1}$ Queen Mary University of London, E1 4NS, UK. \\ ${ }^{2}$ Singapore Botanical Liaison Officer, Herbarium, Royal Botanic Gardens, Kew, \\ Richmond, Surrey TW9 3AE, UK. \\ ${ }^{2}$ Singapore Botanic Gardens, National Parks Board, 1 Cluny Road, \\ Singapore 259569, Singapore. \\ *Corresponding author: i.turner@kew.org \\ ${ }^{1}$ Email: yty0101@sina.com \\ 33Email: m.cheek@kew.org
}

\begin{abstract}
The genus Chassalia (Gentianales: Rubiaceae-Palicoureeae) in Borneo is revised based on a morphological survey of herbarium specimens using classical taxonomic methods. The tribal placement and probable paraphyly of Chassalia as currently delimited is reviewed. Previously, four described species of Chassalia were known from Borneo, with only one endemic species, Chassalia psychotriformis I.M.Turner nom. nov. (ECephaelis psychotrioides Valeton). A key is given to the 18 species of the genus recognised from Borneo in this study. In total, 14 new species are described, all of them endemic to Borneo. These are: Chassalia atropurpurea T.Y.Yu sp. nov., Chassalia beamanii T.Y.Yu sp. nov., Chassalia calamus T.Y.Yu sp. nov., Chassalia chewii T.Y.Yu sp. nov., Chassalia involucrata T.Y.Yu sp. nov., Chassalia kinabaluensis T.Y.Yu sp. nov., Chassalia lancifolia T.Y.Yu sp. nov., Chassalia lancifolioides T.Y.Yu sp. nov., Chassalia longipes T.Y.Yu sp. nov., Chassalia macrocarpa T.Y.Yu sp. nov., Chassalia muluensis T.Y.Yu sp. nov., Chassalia muscicola T.Y.Yu sp. nov., Chassalia northiana T.Y.Yu sp. nov. and Chassalia ramosa T.Y.Yu sp. nov. Circumscriptions and discussions are given for all Bornean species recognised. A morphological glossary for Asian species of Chassalia is provided. Three separate species groups are recognised, the Chassalia curviflora and C. javanica groups, represented by a single species each in Borneo, and a new informal group, the 'Involucrate group', which is proposed and circumscribed to encompass the majority (16) of the Bornean species. Proposals for further work on Asian Chassalia are given.
\end{abstract}

Keywords. Borneo, Cephaelis, involucrate, Mount Kinabalu, Psychotria.

Yu T.Y., Turner I.M. \& Cheek M. 2021. Revision of Chassalia (Rubiaceae-Rubioideae-Palicoureeae) in Borneo, with 14 new species. European Journal of Taxonomy 738: 1-60. https://doi.org/10.5852/ejt.2021.738.1261 


\section{Introduction}

The genus Chassalia Comm. ex Poir. is placed in subfamily Rubioideae tribe Palicoureeae (Robbrecht \& Manen 2006) of the pantropical family Rubiaceae (Razafimandimbison et al. 2008). Rubiaceae represent the fourth most species-diverse flowering plant family, best known for providing coffee (Coffea spp.) (Davis et al. 2009). Genera related to Chassalia in the Palicoureeae are: the early diverging neotropical shrub genera Notopleura (Benth.) Bremek., Palicourea Aubl., Carapichea Aubl. and Rudgea Salisb., followed by Eumachia DC., a pantropical genus of shrubs until recently variously known as Chazaliella E.M.A.Petit \& Verdc. and Margaritopsis C.Wright (Taylor et al. 2017). Eumachia is sister to the palaeotropical Chassalia together with Geophila D.Don and Hymenocoleus Robbr., the last two genera both stoloniferous forest-floor herbs.

To date, the genus Chassalia contains about 120 accepted species, the majority of which are from Africa and Madagascar (Turner 2019). Most species of this genus are erect shrubs and shrublets, sometimes monopodial, or small trees, but several species in West and Central Africa are stem-twining climbers and a few species are epiphytic (Cheek et al. 2004). The morphological characters that are used traditionally to differentiate Chassalia from related genera in the Palicoureeae include the presence of corky (indurated) stipules, flowers usually sessile in capitula, corolla tube usually long, sometimes curved or winged (Bremekamp 1962; Verdcourt 1976).

Razafimandimbison et al. (2014) found that Chassalia as currently circumscribed is paraphyletic with respect to Geophila. Their sampling uncovered three separate clades of Chassalia. They found that "the Southeast Asian Chassalia (represented by a single sample Chassalia sp. -ck25), the East African Chassalia clade, and Geophila sensu stricto, form a basal grade within what could be considered Chassalia in a broad sense. Geophila is in turn sister to Chassalia sensu stricto (including C. capitata DC., to which the type specimen of Chassalia belongs). Therefore, the current circumscription of Chassalia cannot be retained." Razafimandimbison et al. (2014) considered that the preferred option to address this paraphyly would be to represent the Southeast Asian and East African clades as separate genera if features could be found to recognize these clades. They refrained from circumscribing these genera pending further studies.

Borneo is the largest island in Southeast Asia comprising $743330 \mathrm{~km}^{2}$ (Fig. 1). It is situated east of the Malay Peninsula, north of Java and west of the Philippines (Fig. 1). Politically, Borneo is divided between three countries. The southern two-thirds is Indonesian, the northern third Malaysian (the states of Sabah and Sarawak) and a portion of the north is Brunei Darussalam. Borneo lacks volcanoes but comprises a variety of other substrates, including peat-swamp, sand, sandstones, ultramafic and limestone. The main altitudinal forest types are lowland rain forest, lower montane forest and montane forest.

Asian Chassalia has been ignored for a long time, especially for Borneo. A recent nomenclatural study of Chassalia in Asia showed that Asia has 23 accepted species (Turner 2019). Based on Turner's nomenclatural synopsis, the Malay Peninsula has 14 of the 23 Asian species of Chassalia, among which 13 are endemic to the Peninsula.

From a survey of the checklists of Borneo plants and of Turner's nomenclatural study of Chassalia, four species of Chassalia are known to have been described from Borneo (Merrill 1921; Beaman \& Anderson 2004; Turner 2019). These species are C. curviflora (Wall.) Thwaites, C. javanica (Blume) I.M.Turner, C. blumeana Govaerts and C. psychotriformis I.M.Turner. Among them just one species, C. psychotriformis, is endemic to Borneo, occurring mostly in Southern Borneo (Merrill 1921, sub Cephaelis psychotrioides Valeton).

In Asia some species of Chassalia which have capitate or involucrate inflorescences were previously referred to Cephaelis Sw. Cephaelis, formerly considered a pantropical genus, was recognized by its involucrate, capitate inflorescences. Subsequently it became clear that this was a case of convergent 
evolution. African species of Cephaelis are now included in Psychotria L. (Psychotrieae) while many neotropical Cephaelis are accommodated in Palicourea (Palicoureae) (Razafimandimbison et al. 2014). Cephaelis is no longer an accepted genus. Asian, including Bornean, Chassalia and Psychotria can be separated using the following key:

1. Stipules soon chaffy (indurated), usually entire; pyrenes usually with a ventral excavation, and with a ventral, basal pre-formed germination slit (PGS)

Chassalia Comm. ex Poir.

- Stipules never chaffy or indurated, usually bifid; pyrenes lacking a ventral excavation, pre-formed germination slits not present

Psychotria L.

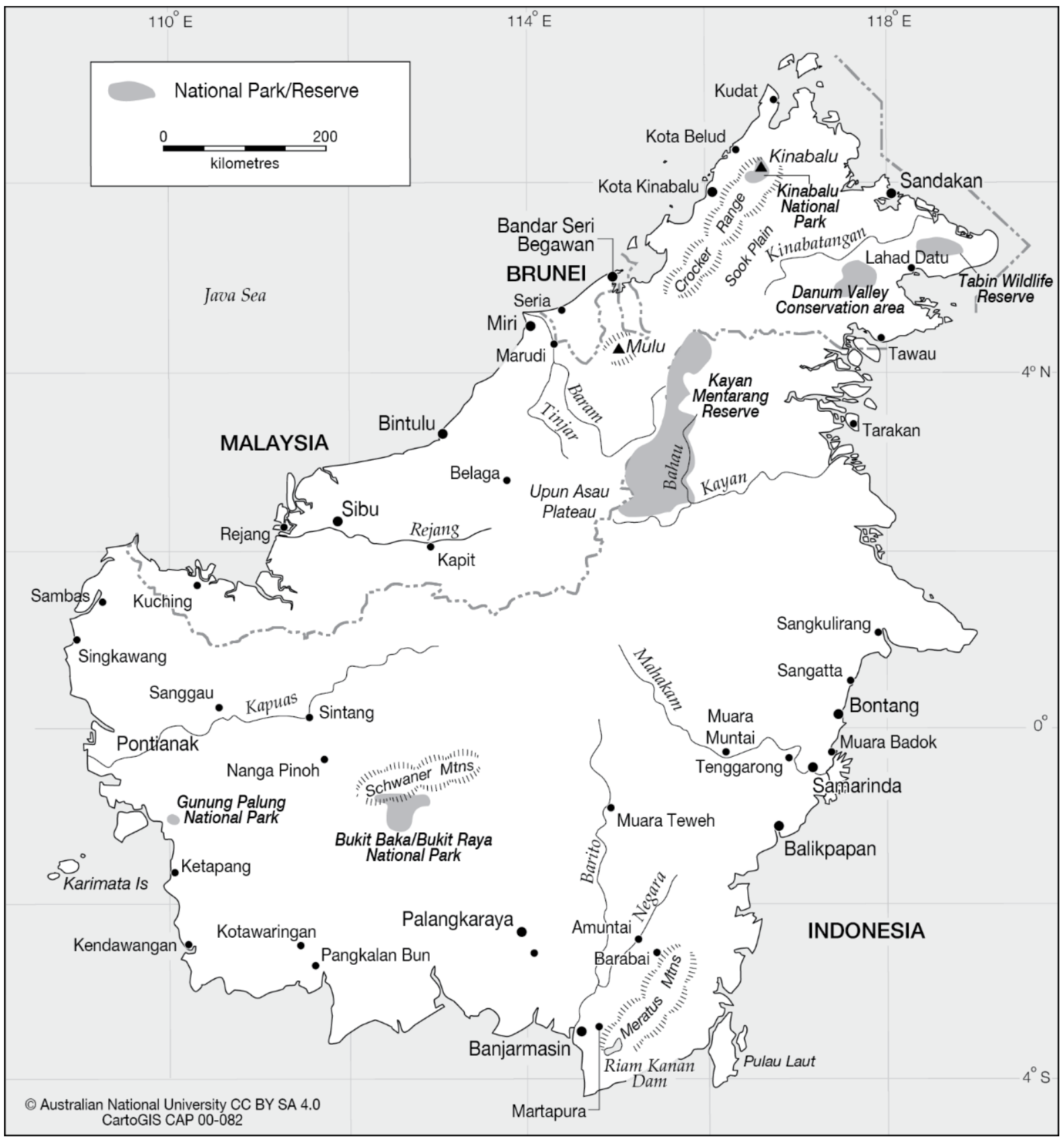

Fig. 1. Map of Borneo. 
Asian species previously accommodated in Cephaelis were recently transferred to Chassalia on this basis (Ruhsam et al. 2008; Turner 2019).

Merrill (1921) listed for Borneo two species of Cephaelis, Cephaelis psychotrioides Valeton and Cephaelis stipulacea Blume, which are now both included in the genus Chassalia. Two other species of Chassalia were also listed by Merrill for Borneo: Chassalia gracilis Stapf which was transferred to the genus Psychotria (Turner 2019), and Chassalia lurida Miq. which is now a synonym of Chassalia curviflora. Davis et al. (1996) listed two named species for Brunei. These were Chassalia bracteata Ridl., which we do not consider to occur in Borneo, and Chassalia chartacea Craib, which we consider to be a synonym of C. curviflora. Beaman \& Anderson (2004) recorded three species of Chassalia for Mount Kinabalu, with one described species Chassalia chartacea Craib which is now treated as a synonym of Chassalia curviflora (Turner 2019), and two undescribed species Chassalia sp. 1 and Chassalia sp. 2 which included most of the specimens of Chassalia collected on and around Mount Kinabalu. The specimens that Beaman \& Anderson (2004) cited of their two undescribed species from Mount Kinabalu are now described in this article as four new species.

In their synopsis of the genera of the Rubiaceae in Borneo, Wong \& Puff (1993) referred to Chassalia as a genus badly in need of revision. We present our study as a first step towards revising the genus on the island of Borneo. We describe 14 new species, all of which are illustrated, and provide a key to the identification of all 18 species of Chassalia recognized for Borneo. This study mainly focuses on the morphological characteristics of each species based on herbarium specimens. An analysis of the molecular phylogeny of the genus is beyond the scope of the present study.

\section{Material and methods}

This study is mainly based on the herbarium specimens, including corresponding field notes, at the herbarium of the Royal Botanic Gardens, Kew (K) including loans from the Singapore Botanic Garden Herbarium (SING) and Forest Research Institute Malaysia (KEP). It is also based on the study of digital images of herbarium specimens from other herbaria, mainly from Herbarium Bogoriense (BO) and National Herbarium of the Netherlands (L). Herbarium codes follow Index Herbariorum (Thiers continuously updated). Specimens seen are indicated by '!'.

Nomenclatural changes were made according to the Shenzhen Code (Turland et al. 2018). Names of species and authors follow IPNI (continuously updated). Herbarium material was examined with a Leica Wild M8 dissecting binocular microscope fitted with an eyepiece graticule measuring in units of $0.025 \mathrm{~mm}$ at maximum magnification. The drawings were made with the same equipment with a Leica 308700 camera lucida attachment. It was necessary to boil the flowers and fruits to rehydrate them so as to allow dissection and observation of the inner structures of the corolla and pyrene. The format of the descriptions follows those in other papers describing new species in Chassalia (e.g., Cheek \& Csiba 2000; Sonké et al. 2007). Terminology for specialised structures, e.g., for colleters, generally follows Robbrecht (1988). For describing the morphological structures of Bornean Chassalia, an illustrated glossary has been made and used in this study (Figs 2-3). Measurements were made of stems, leaves, inflorescences, infructescences, flowers and fruits using a graduated ruler. In every description the range of measurements is given with extreme dimensions indicated in parentheses.

\section{Results}

Based on the current study of herbarium specimens and related literature, 18 species of Chassalia in total are recognised in Borneo. In addition to the four previously described species which are C. javanica, C. curviflora, C. psychotriformis and C. blumeana, 14 new species were discovered hiding among specimens, some of which were collected more than 100 years ago. In this study the species were 


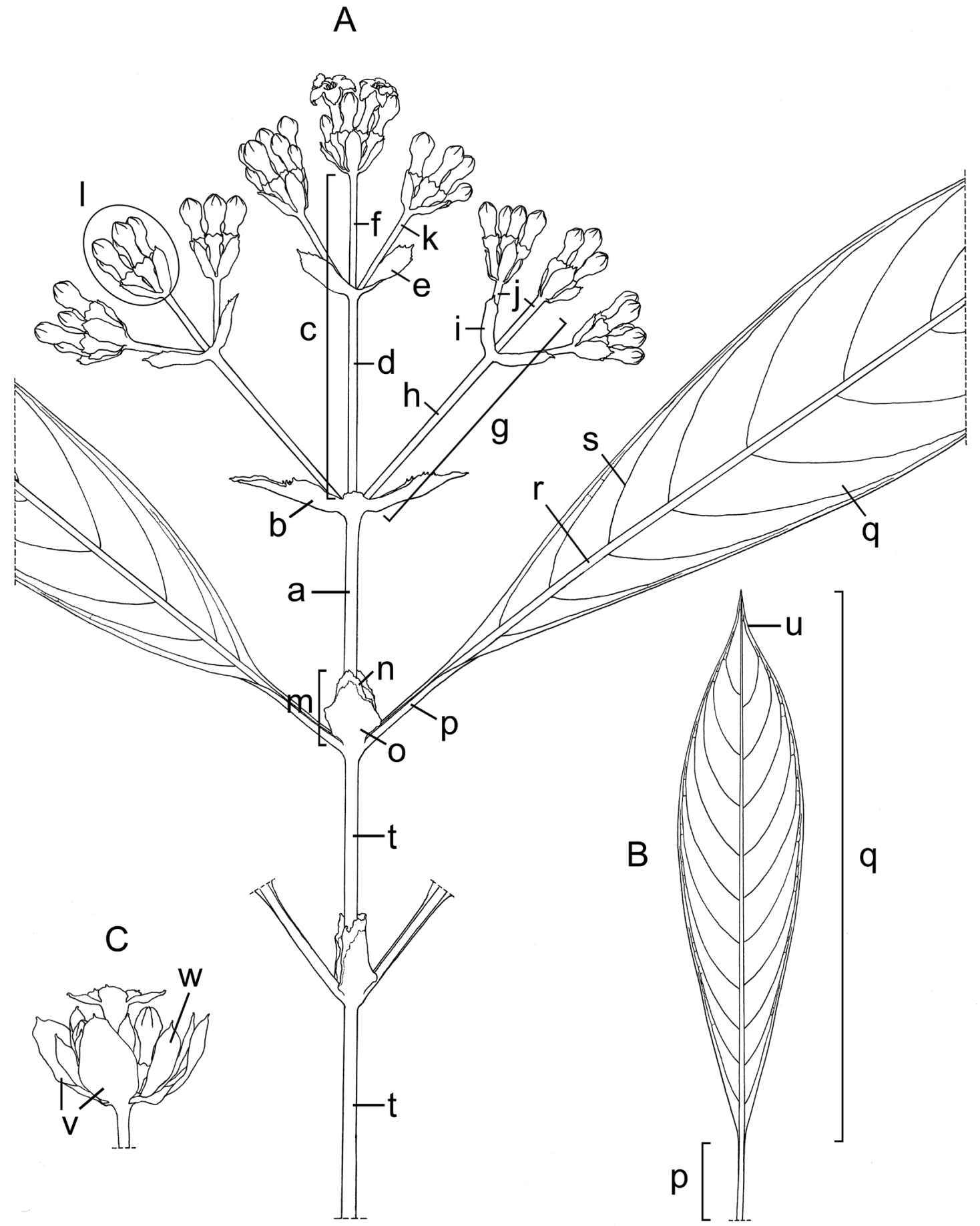

Fig. 2. Morphological glossary of Chassalia Comm. ex Poir. in Borneo; $\mathrm{A}-\mathrm{B}=$ C. kinabaluensis T.Y.Yu sp. nov.; $\mathrm{C}=$ C. chewii T.Y.Yu sp. nov. A. Shoot with terminal inflorescence. B. Leaf. C. Capitulum. a = peduncle; $\mathrm{b}=$ bract subtending first internode of rachis; $\mathrm{c}=$ rachis; $\mathrm{d}=$ first internode of rachis; $\mathrm{e}=$ bract subtending second internode of rachis; $f=$ second internode of rachis; $g=$ first branch; $h=$ first internode of first branch; $i=$ bract subtending second internode of first branch; $j=$ second internode of first branch; $\mathrm{k}=$ second branch; 1 = capitulum; $\mathrm{m}=$ stipule; $\mathrm{n}=$ apical (chaffy) part of stipule; $\mathrm{o}=$ basal (membranous) part of stipules; $\mathrm{p}=$ petiole; $\mathrm{q}=$ leaf-blade; $\mathrm{r}=$ midrib; $\mathrm{s}=$ secondary nerve; $\mathrm{t}=$ internode; $\mathrm{u}=$ acumen; $\mathrm{v}=$ outer (capitular) bracts; $\mathrm{w}=$ inner (capitular) bract. Drawn by T.Y. Yu. 

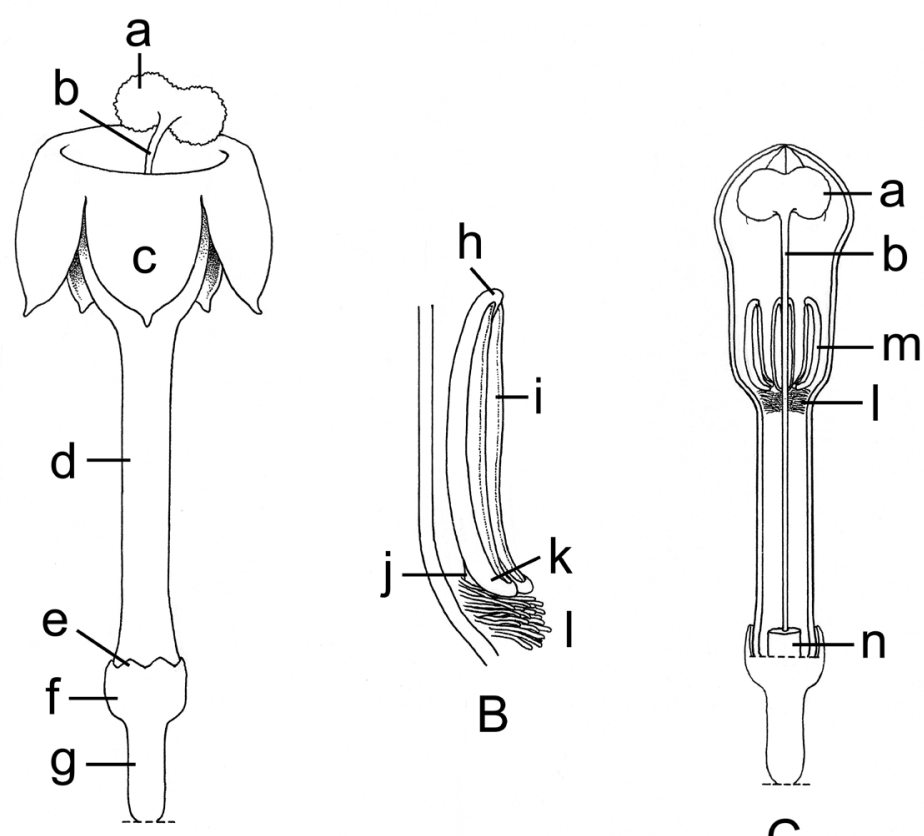

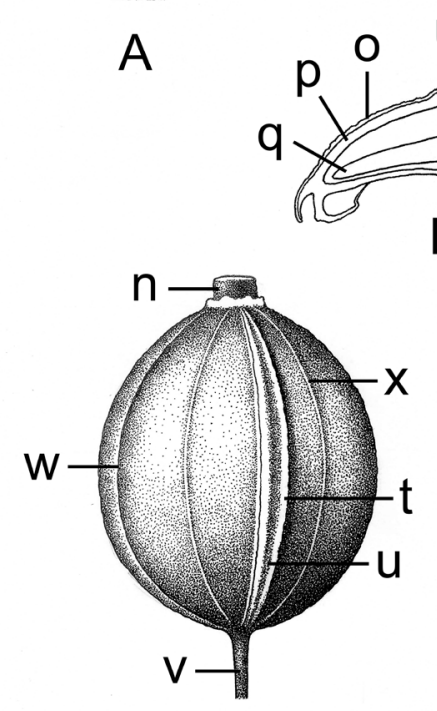

$E$
C 
described mainly based on Kew herbarium specimens but supplemented by loans from the institutes indicated. All the newly described species appear to be Borneo endemic species: none was found on other islands or on mainland Asia. A key to all Bornean species of Chassalia is presented below. Treatments of all 18 species are presented in alphabetical order, with descriptions of all new species to science.

In Borneo, species of Chassalia, including the new species described here, can be found from sea level to approximately $2000 \mathrm{~m}$ a.s.l. They occur in forest habitats in peat-swamp and well-drained habitats and on both ultramafic and non-mafic substrates.

Different species of Chassalia live in a wide range of different habitats; most of the larger-leaved species prefer lowland forest while some of the smaller-leaved species are restricted to summits with montane forest. Some of the previously known biodiversity hotspots in Borneo are also centres of diversity for species of Chassalia, such as Mount Kinabalu, Mount Matang, Brunei and Gunung Mulu.

\section{Key to species of Chassalia Comm. ex Poir. in Borneo}

1. Plant epiphytic, fruit narrowly ellipsoid, 3-4 mm wide, pyrene dorsal surface with a central groove, pyrene ventral surface with a central groove and ridge as high as plane of endocarpal outgrowth

Chassalia javanica (Blume) I.M.Turner

- Plant terrestrial (sometimes epiphytic in C. muluensis), fruit ellipsoid or globose, $>5 \mathrm{~mm}$ wide, pyrene dorsal surface with 1 or 2 central longitudinal crests, pyrene ventral surface with a central ridge lower than the plane of the endocarpal outgrowth

2. Stipules bilobed to the base, apex of lobes caudate; inflorescences with 2-3 toothed stipule-like bracts usually $<5 \mathrm{~mm}$ long, corolla tubes curved, usually winged; pyrene dorsal surface with 1 central longitudinal crest ..................................... Chassalia curviflora (Wall.) Thwaites complex

- Stipule margins entire, incised or 1-3 toothed, usually not bilobed, if bilobed then by $<1 / 3$ the length; inflorescences with bracts $>5 \mathrm{~mm}$ long at secondary peduncle node and each capitulum; corolla tubes not curved or winged; pyrene dorsal surface with 2 central, adjacent longitudinal crests ...... 3

3. Herb or small shrub, 25-30 cm tall; fruit white when ripe ...... Chassalia muscicola T.Y.Yu sp. nov.

- Herb, shrub or tree, taller than $40 \mathrm{~cm}$; fruit bluish green, blue, purplish green or dark purple when ripe

4. Abaxial surface of leaves with midrib and secondary nerves densely pubescent

Chassalia psychotriformis I.M.Turner nom. nov.

- Abaxial surface of leaves with midrib and secondary nerves glabrous

5. Inflorescences longer than longest leaves (Mount Kinabalu) ..... Chassalia longipes T.Y.Yu sp. nov.

- Inflorescences shorter than longest leaves

6. Stem, petiole, nerves of leaves abaxially and peduncle blackish purple, corolla usually purplish white Chassalia atropurpurea T.Y.Yu sp. nov.

- Stem and petiole green or purplish green, nerves of leaves abaxially and peduncle green, corolla white, cream white or yellowish white

7. Bracts of capitulum not covering top of calyx at anthesis (Kinabalu)

Chassalia kinabaluensis T.Y.Yu sp. nov.

- Bracts of capitulum covering top of calyx at anthesis

8. Leaf-blades lanceolate to narrowly elliptic, 5-10 times as long as wide

- Leaf-blades elliptic, oblong, obovate or ovate, 2-4 times as long as wide 
9. Bracts of capitulum 10-12 $\times 5-10 \mathrm{~mm}$, usually equal to or longer than flower buds; fruits $10-12 \mathrm{~mm}$ long (Kuching)

Chassalia macrocarpa T.Y.Yu sp. nov.

- Bracts of capitulum 3-6 $\times 2-6 \mathrm{~mm}$, usually shorter than flower buds; fruits $<8 \mathrm{~mm}$ long ........... 10

10. Leaf-blades elliptic or oblanceolate, 5-7 times as long as wide (Kuching)

Chassalia lancifolia T.Y.Yu sp. nov.

- Leaf-blades narrowly lanceolate, 8-10 times as long as wide (Kuching)

Chassalia lancifolioides T.Y.Yu sp. nov.

11. Longest leaf-blades usually longer than $25 \mathrm{~cm}$, inflorescences $<6 \mathrm{~cm}$ long, peduncle $<4 \mathrm{~cm}$ long ..

- Longest leaf-blades usually shorter than $20 \mathrm{~cm}$, inflorescences $\geq 6 \mathrm{~cm}$ long, peduncle $>4 \mathrm{~cm}$ long .

12. Bracts of capitulum covering fruits (Sarwak, Sabah and Brunei)

Chassalia involucrata T.Y.Yu sp. nov.

- Bracts of capitulum not covering fruits

13. Stems 5-12 mm diameter, internodes 3-6 cm long (Sabah: Tambunan and Ranau)

- Stems 4-6(-8) mm diameter, internodes 1-3 cm long (Sabah: Kinabalu)

Chassalia calamus T.Y.Yu sp. nov.

Chassalia beamanii T.Y.Yu sp. nov.

14. Rachis and branches of inflorescence $<4 \mathrm{~mm}$ long or absent, capitulum condensed into 1 head .. 15

- Rachis and branches of inflorescence $>10 \mathrm{~mm}$ long, capitulum not condensed into 1 head ......... 16

15. Plant only producing 1 flowering branch on old stems, bracts of capitulum $\leq 5 \mathrm{~mm}$ long

Chassalia blumeana Govaerts

- Plant usually producing 2 flowering branches on old stems, bracts of capitulum $\geq 10 \mathrm{~mm}$ long

Chassalia ramosa T.Y.Yu sp. nov.

16. Peduncle $\leq 1 \mathrm{~cm}$ long, bracts of capitulum longer than flowers and fruits

Chassalia chewii T.Y.Yu sp. nov.

- Peduncle $>1 \mathrm{~cm}$ long, bracts of capitulum shorter than flowers and fruits

17. Inflorescences usually longer than first pair of leaves; secondary nerves 16-18 on each side of the midrib (Gunung Mulu endemic) Chassalia muluensis T.Y.Yu sp. nov.

- Inflorescences usually shorter than first pair of leaves; secondary nerves 8-14 on each side of the midrib (Sabah and Sarawak) Chassalia northiana T.Y.Yu sp. nov. 


\section{Taxonomic treatments}

Order Gentianales Juss. ex Bercht. \& J.Presl

Family Rubiaceae Juss.

Genus Chassalia Comm. ex Poir.

Chassalia atropurpurea T.Y.Yu sp. nov.

urn:lsid:ipni.org:names:77215402-1

Figs 4-5

\section{Diagnosis}

Differs from all other species of Chassalia in Borneo in the stem, petioles, abaxial venation of leaves, peduncles and fruits being blackish purple, both when dried and living (field notes); flowers cream white flushed purple-black; stipule long, elliptic; inflorescence well-developed, peduncle long, bracts of tertiary peduncle usually long, lanceolate.

\section{Etymology}

The epithet reflects the blackish purple coloration of stem, petioles, abaxial venation of leaves, peduncles and fruits which is distinct compared to all other Bornean species of Chassalia.

\section{Type}

MALAYSIA - Borneo, Sarawak $\cdot 2^{\text {nd }}$ Division, Lubok Antu District, Lanjak-Entimau P.F., Bukit Lanjak; 14 Mar. 1974; Paul Chai S 33830; holotype: K[K001129719]![K001129720]! (2 sheets 1 specimen); isotypes: L, KEP[KEP271656]! [KEP271657]! (2 sheets 1 specimen), MO, SAN.

\section{Additional material}

MALAYSIA - Borneo, Sarawak • $7^{\text {th }}$ Division, Ulu Sg. Kapit, Summit of Bukit Goram; 28 Feb. 1975; Paul Chai S 36121; K!, L, KEP, MO, SAN - Sri Aman Division, Ulu Batang Ai, Bukit Lanjak; alt. 1350 m; 6 Mar. 1994; Yii Puan Ching et al. S 67509; K!, KEP, L, SAN • $2^{\text {nd }}$ Division, Bukit Bangai, Ulu Lemanak; alt. 915 m; 26 Oct. 1961; S. Collenette 842; K!.

\section{Description}

Shrub to small treelet, $0.8-1.5 \mathrm{~m}$ tall, glabrous. Stem blackish purple, terete, not hollow. Internodes deeply canaliculate, (1.5-)3.5-7.5 cm long. Leaf-blades narrowly elliptic to lanceolate, 9-16 × 1.5-4 cm, apex acuminate, acumen $0.5-1.3 \mathrm{~cm}$ long, base cuneate to attenuate, first pair of leaves from apex sometimes very small, $1-3 \mathrm{~cm} \times 3-5 \mathrm{~mm}$. Petiole blackish purple, slightly flattened, $0.9-1.5 \mathrm{~cm}$ long. Midrib and secondary veins slightly raised both abaxially and adaxially, secondary veins 8-12 on each side of the midrib and blackish purple abaxially, leaf-blade sometimes slightly impressed around secondary veins, tertiary veins not visible. Stipule elliptic to trapezoidal, 2-12 × 3-9 mm, broken stipules from lower nodes sometimes slightly bilobed. Inflorescences compound cymes, usually well-developed, peduncle canaliculate, (1.5-)3.5-6 cm long blackish purple, bracts of first internode of rachis and first branches elliptic, 4-5 × 1.5-2 mm, first internode of rachis and first branches canaliculate, $(0.5-) 1.5-6 \mathrm{~cm}$ long, bract of second internode of rachis and second branches ovate, $3 \times 3 \mathrm{~mm}$, second internode of rachis and second branches 1-2 cm long. Bracts of capitulum 4,2 $1 \mathrm{~mm}$. Flowers ca 10 in each capitulum, more or less sessile, hypanthium ca $1 \mathrm{~mm}$ long, calyx tube ca $0.5 \mathrm{~mm}$ long, lobes triangular, ca $0.2 \mathrm{~mm}$ long, corolla white flushed purple, $11-12 \mathrm{~mm}$ long at largest point in bud before corolla lobes separate, lower tube straight, ca $5 \mathrm{~mm}$ long, $0.5-0.8 \mathrm{~mm}$ diameter, distal portion inflated, turbinate with top domed, ca $6 \mathrm{~mm}$ long, ca $3 \mathrm{~mm}$ maximum diameter, corolla lobes oblong-ovate 2-3 $\times 2 \mathrm{~mm}$, apex apiculate with a thickened tip. Stamens $2 \times 0.4 \mathrm{~mm}, 2 \mathrm{~mm}$ from apex of corolla tube, $6.5 \mathrm{~mm}$ from base of corolla tube, anthers with an apical connective appendage $1 \mathrm{~mm}$ long, filaments very short, less than $0.1 \mathrm{~mm}$ 


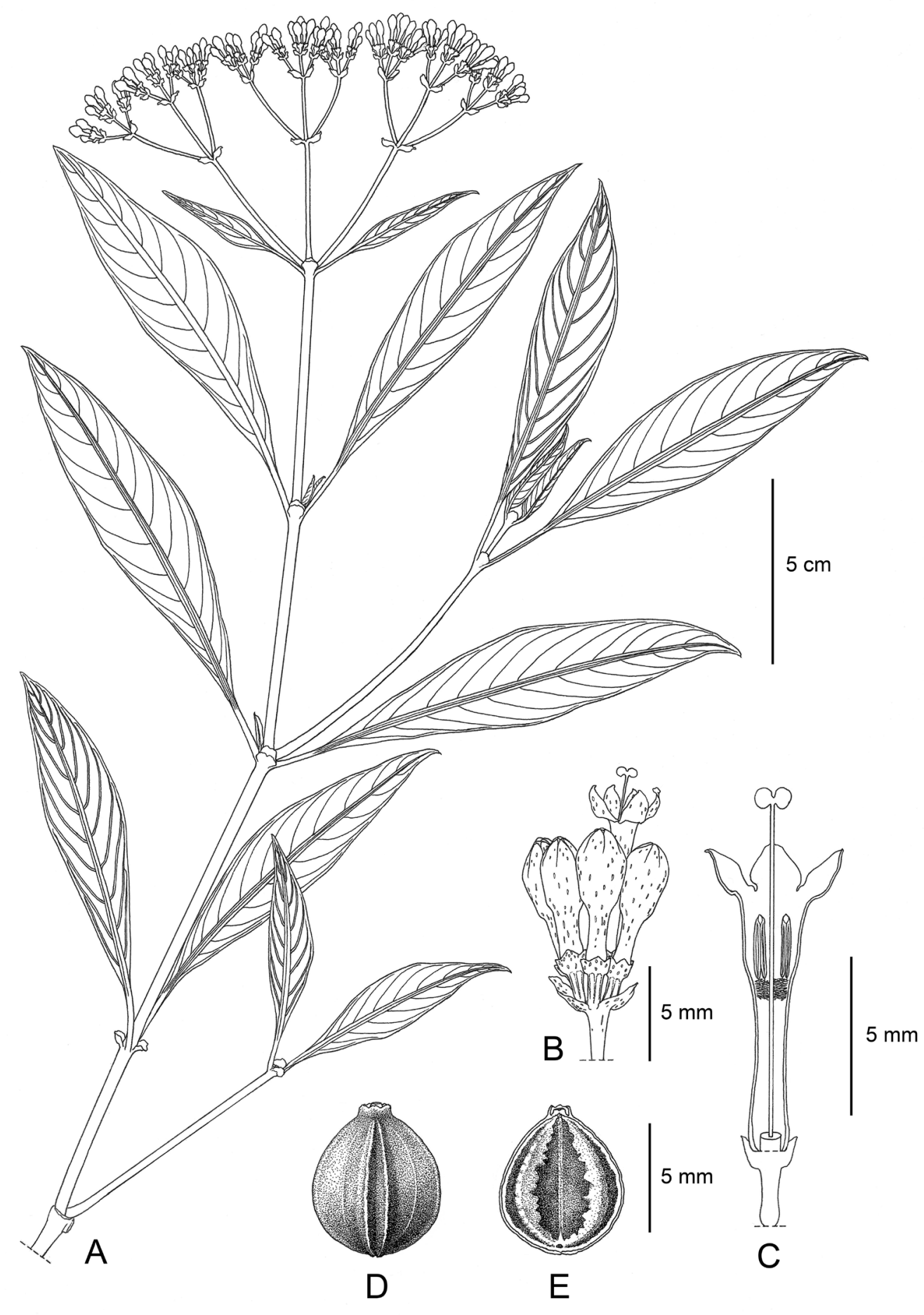

Chassalia atropurpurea T.Y.Y.

Fig. 4. Chassalia atropurpurea T.Y.Yu sp. nov. A. Flowering shoot. B. Capitulum. C. Longitudinal view of corolla. D. Dry fruit. E. Pyrene ventral surface. A-C from Paul Chai S 33830; D-E from Paul Chai $S$ 36121. Drawn by T.Y. Yu. 


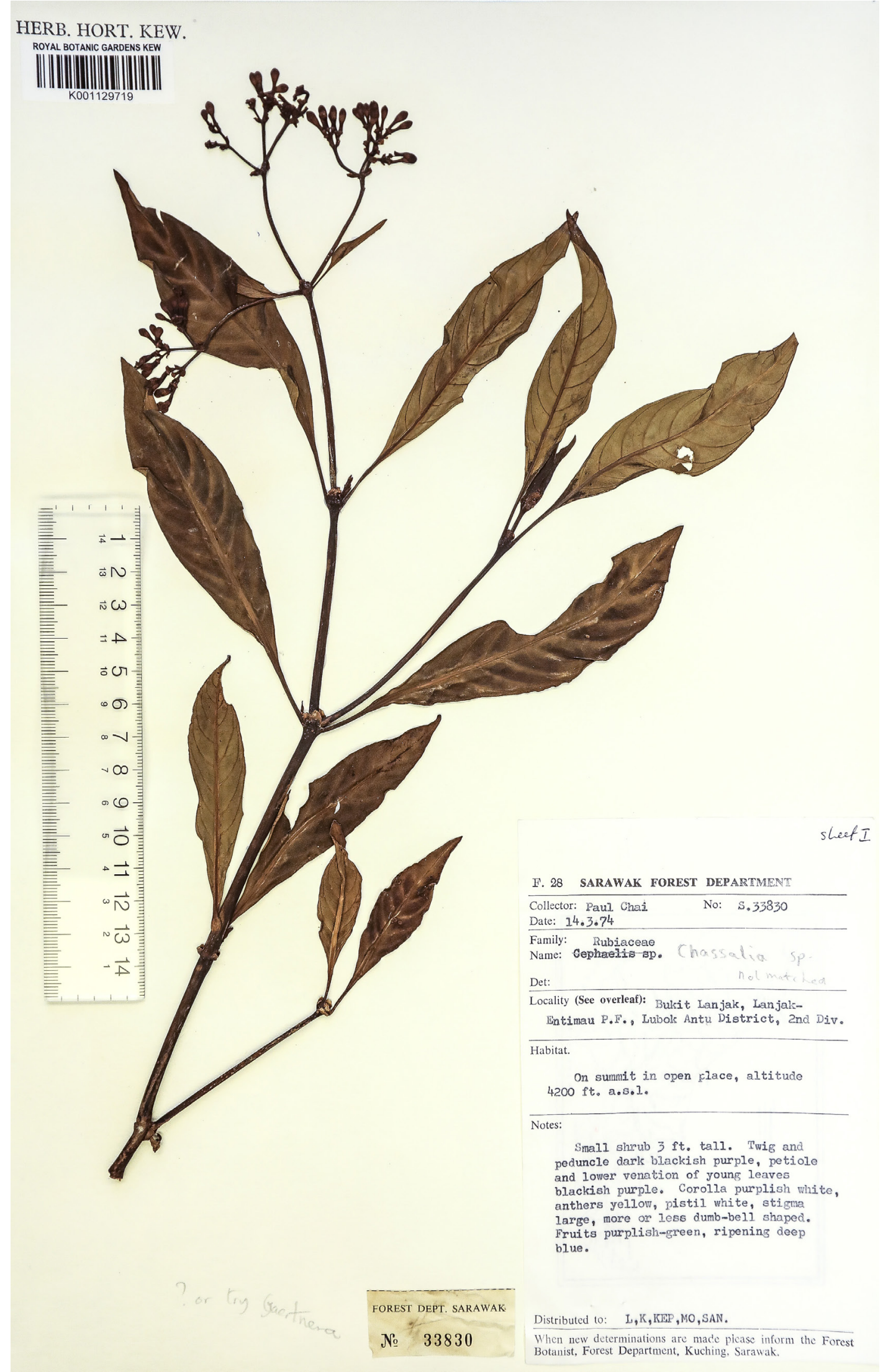

Fig. 5. Part of holotype of Chassalia atropurpurea T.Y.Yu sp. nov. (Paul Chai S 33830); sheet 1 of 2. 
long, band of hairs at base of stamens $1 \mathrm{~mm}$ wide, each hair around $0.2 \mathrm{~mm}$ long. Style $12 \mathrm{~mm}$ long, exserted about $2 \mathrm{~mm}$ from mouth of corolla, stigma bilobed, each lobe orbiculate, $0.8 \mathrm{~mm}$ diameter. Disc cylindric, $0.8 \times 0.8 \mathrm{~mm}$. Fruits ellipsoid, $6 \times 5.5 \times 4.5 \mathrm{~mm}$, dark purple to iridescent blue, calyx persistent, not accrescent, $2 \times 2 \mathrm{~mm}$, disc persistent, not accrescent, $0.5 \times 1.2 \mathrm{~mm}$. Pyrene plano-convex, $8-9 \times 5.5 \times 2.5-3 \mathrm{~mm}$, dorsal surface convex, with two adjacent parallel longitudinal crests, $0.4 \mathrm{~mm}$ wide, $0.25 \mathrm{~mm}$ apart along their length, forming a longitudinal groove from apex to base between the two crests; ventral surface concave, central part slightly elevated, margin with an endocarpal outgrowth $1 \mathrm{~mm}$ wide, with a groove between the edge of endocarp and endocarpal outgrowth $0.5 \mathrm{~mm}$ wide. Raphal opening at base of the endocarpal outgrowth, round, $0.4 \mathrm{~mm}$ wide, $0.2-0.3 \mathrm{~mm}$ from the edge of the pyrene wall, apex with a bony spine, spine triangular, erect, $0.8 \mathrm{~mm} \times 0.2 \mathrm{~mm}$. PGS not detected. Seed light brown, hemi-ellipsoid, $0.5 \mathrm{~mm} \times 6 \mathrm{~mm}$, longitudinally slightly crested at midline of dorsal surface, endosperm not detected.

\section{Distribution, habitat}

Borneo: Sarawak. High-altitude (910-1350 m a.s.1.) summit montane forest, open places.

Chassalia beamanii T.Y.Yu sp. nov. urn:lsid:ipni.org:names:77215403-1

Figs 6-7

\section{Diagnosis}

Differs from other big-leaved species in having leaves clustered at apex of stem, in infructescences mostly terminal, in fruits significantly obovoid (fruits of most other Asian species of Chassalia are ovoid or round).

\section{Etymology}

Named after American botanist, John Homer Beaman (1929-2015), who collected this species and most other specimens of Chassalia from around Mount Kinabalu.

\section{Type}

MALAYSIA - Borneo, Sabah - Ranau District, near Poring Hot Springs along trail to tourist canopy walkway; 603' N, 11042' E; 9 Aug. 1990; John H. Beaman 10924; holotype: K[K001129721]!; isotype: MSC.

\section{Additional material}

MALAYSIA - Borneo, Sabah • Ranau District, Kampung Melangkap Tomis, 3 km dari Melangkap Tomis; 10 Sep. 1995; Lorence Lugas 954; K!, SNP• Kawasan Labi; 14 Jan. 1996; Lorence Lugas 1676; $\mathrm{K}$ !, SNP.

\section{Description}

Shrub or small treelet, around $1 \mathrm{~m}$ tall, glabrous. Stem terete, hollow, slightly flattened when dry, 4-6(8) $\mathrm{mm}$ wide; successive nodes flattened at right angles, internode on the flowering branch 1-3 cm long, gradually compressed at apex. Leaves opposite, decussate. Leaf-blades obovate to broadly elliptic, $21-$ $28 \times 7-11 \mathrm{~cm}$, broadest at about middle or above; apex acute to attenuate; base attenuate; midrib slightly raised above, domatia absent; secondary nerves $12-18$ on each side of the midrib, prominent above. Petioles flattened, canaliculate, $3-4 \times 0.1-0.2 \mathrm{~cm}, 1 \mathrm{~cm}$ long when immature. Stipule not sheathing, broadly flabellate, $5-10 \times 8-15 \mathrm{~mm}$, apex broken very easily, base drying deep brown, 5-8 $\times 8-10 \mathrm{~mm}$, sometimes very small, $3 \times 2 \mathrm{~mm}$; margin light brown. Inflorescences compound cymes, $1.5-4 \mathrm{~cm}$ long; 


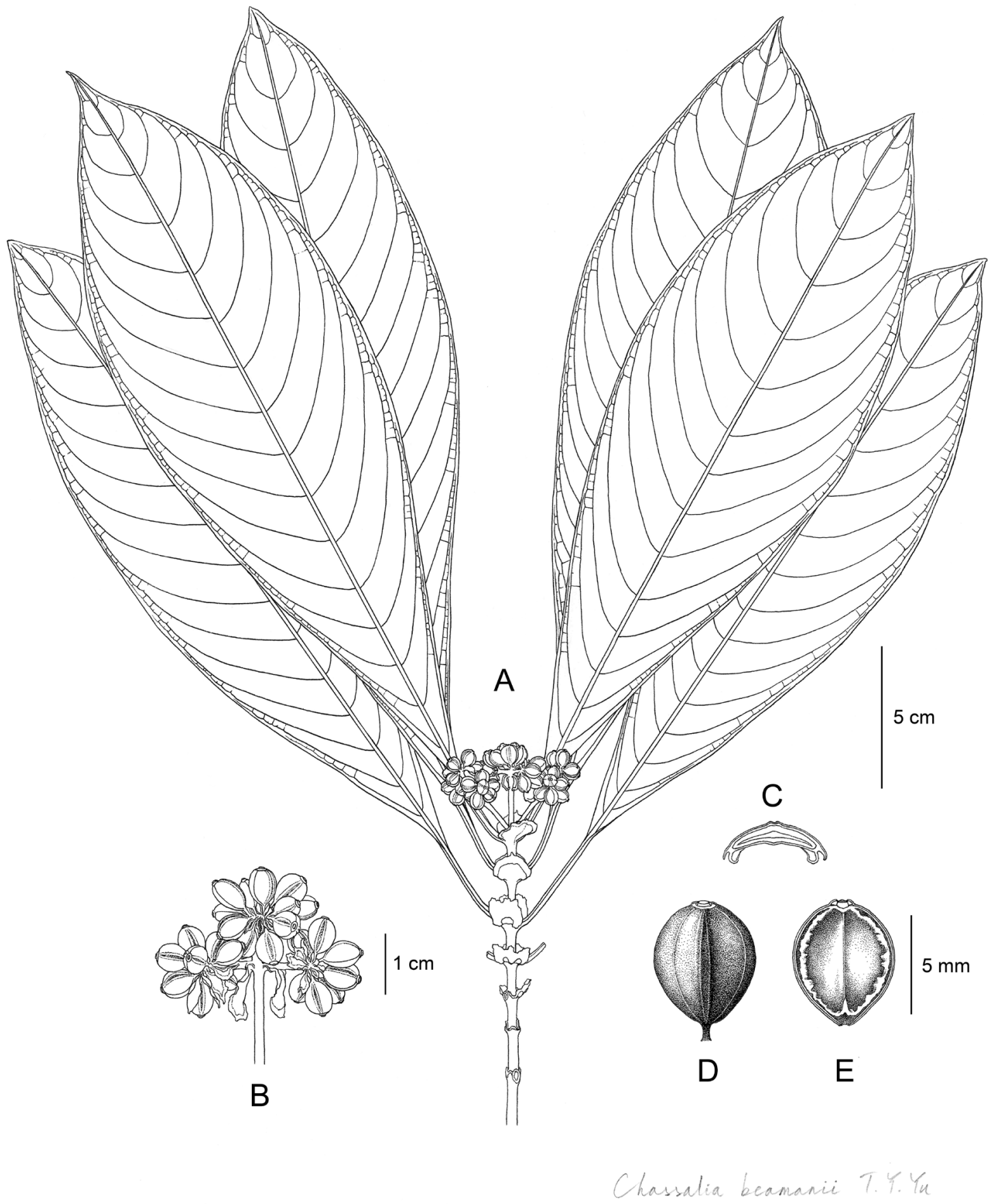

Fig. 6. Chassalia beamanii T.Y.Yu sp. nov. A. Flowering shoot. B. Infructescence. C. Pyrene transection. D. Dry fruit. E. Pyrene ventral surface. From John H. Beaman 10924. Drawn by T.Y. Yu. 


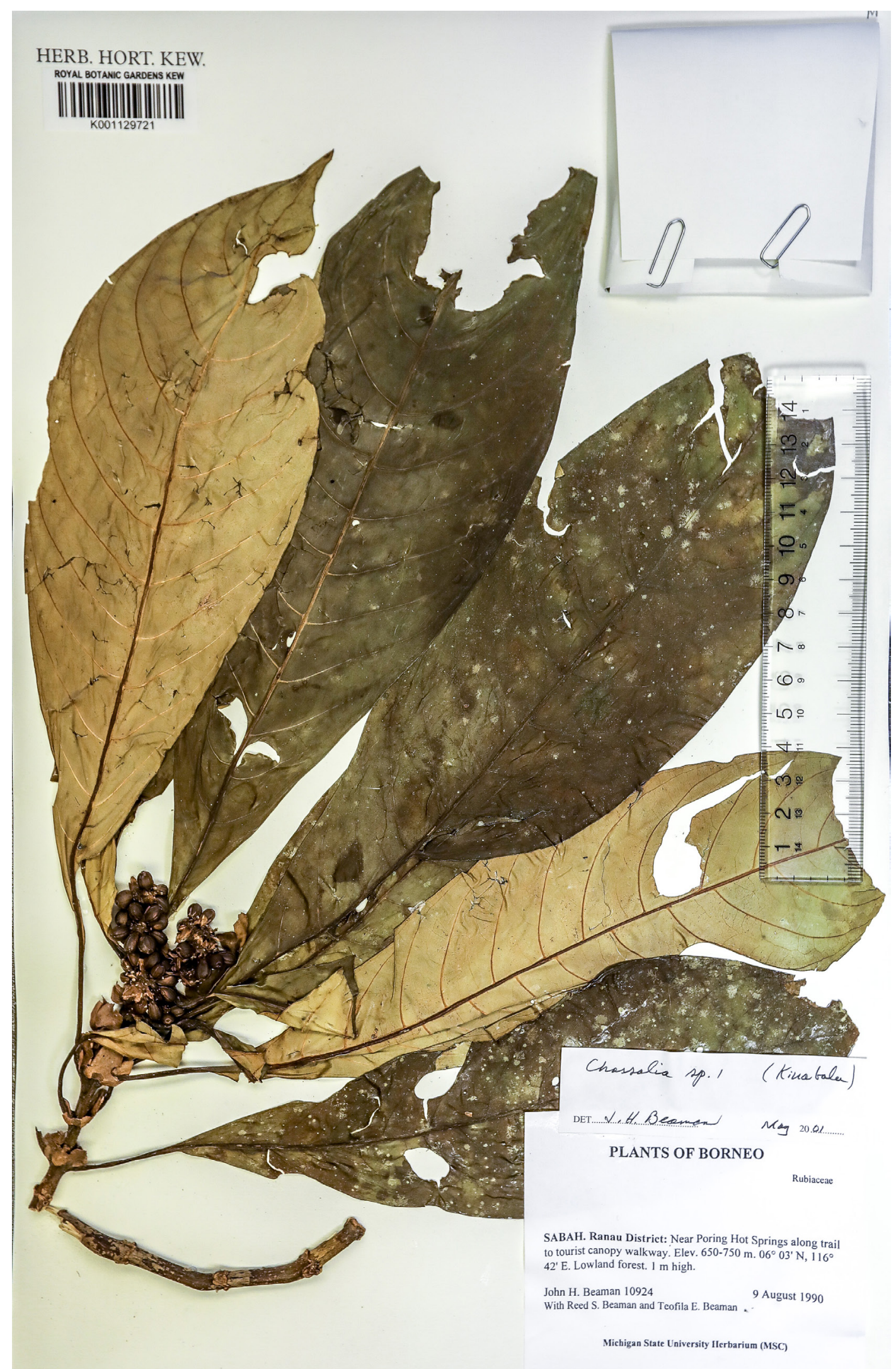

Fig. 7. Holotype of Chassalia beamanii T.Y.Yu sp. nov. (John H. Beaman 10924). 
peduncle 8-20 $\times 2 \mathrm{~mm}$, rachis and branches $3-15 \mathrm{~mm}$ or absent. Bracts $4-9$ in each capitulum, 3-6 $\times$ 3-4 mm. Flowers not seen. Fruits obovoid, broadest at $2 / 3$ from base, 6-7 $\times 4-6 \mathrm{~mm}$, with $2-3$ veins visible on pericarp; pedicel of fruit short, $2-3 \mathrm{~mm}$; calyx tube persistent or broken, $0.5-1 \times 1-2 \mathrm{~mm}$, lobes usually broken. Disc persistent, longer than persistent calyx tube, $0.8-1.2 \times 0.7-0.8 \mathrm{~mm}$. Pyrenes plano-convex, dorsal surface convex, with two adjacent parallel longitudinal crests, each $0.1 \times 0.3 \mathrm{~mm}$, curved, $0.3 \mathrm{~mm}$ apart along their length, forming a longitudinal groove from apex to base between the two crests; ventral surface concave, central part slightly elevated, margin with an endocarpal outgrowth $0.3 \times 0.6 \mathrm{~mm}$, with a groove between the edge of endocarp and endocarpal outgrowth $0.2-0.3 \mathrm{~mm}$ wide. Raphal opening at base of the endocarpal outgrowth, narrowly ovoid, $0.5 \times 0.2 \mathrm{~mm}, 0.2-0.3 \mathrm{~mm}$ from the edge of the pyrene wall, apex with a bony spine, spine triangular, erect, $0.5-0.7 \times 0.2-0.3 \mathrm{~mm}$. PGS not detected. Seed light brown, hemi-ellipsoid, slightly crested at central part of dorsal side, $0.3 \times 4 \mathrm{~mm}$, endosperm not detected.

\section{Distribution, habitat}

Endemic to Borneo. Only known from the Ranau District of Sabah. Lowland forest, alt. 650-750 m.

\section{Chassalia blumeana Govaerts}

Botanical Journal of the Linnean Society 157: 119 (Ruhsam et al. 2008).

Replaced synonym:

Cephaelis stipulacea Blume, Bijdragen tot de flora van Nederlandsch Indië (16): 1005 (Blume 1826-1827). - Uragoga stipulacea (Blume) K.Schum. in Engler \& Prantl, Die natürlichen Pflanzenfamilien 4 (4-5): 120 (Schumann 1891). - Uragoga blumeana Kuntze, Revisio generum plantarum 2: 955 (Kuntze 1891a), nom. illegit. (superfl.). - Chassalia stipulacea (Blume) Piessch., Flora 196: 128 (Piesschaert et al. 2001), nom. illegit., non Chassalia stipulacea DC., Prodromus Systematis Naturalis Regni Vegetabilis 4: 532 (1830) (Candolle 1830). - Type: JAVA • C.L. Blume s.n.; hololectotype: L[L 0057738], designated by Turner (2019: 397).

\section{Description}

Shrub to small tree, height unknown. Stem terete, canaliculate with 2 longitudinal grooves when dry. Internodes 1.5-3.5 cm long. Stipule flabellate, 4-5 × 6-8 mm, Leaf-blades obovate to elliptic, 27-29 $\times$ $8.5-9 \mathrm{~cm}$, apex acuminate, acumen $1-1.5 \mathrm{~cm}$, base truncate, slightly decurrent to petiole, midrib slightly raised at adaxial and abaxial, secondary nerves 12 from each side of the midrib. Petioles $2.5-3.5 \mathrm{~cm}$ long, 1.5-2 mm wide. Inflorescence/flowers not seen. Infructescence one per stem, compound cyme with 3 capitula appearing as one head, $4 \mathrm{~cm}$ long, peduncle $3 \times 0.3 \mathrm{~mm}$, branches and rachis $2-4 \mathrm{~mm}$ long, bracts of rachis and branches 2, ovate, $0.5 \times 0.4 \mathrm{~mm}$, bracts of capitulum ovate with a chaffy edge, 4-5 $\times 5 \mathrm{~mm}$. Pedicel of fruit 3-5 mm long. Fruit ellipsoid to ovoid, $8-11 \times 5-7 \times 5 \mathrm{~mm}$, calyx persistent, not accrescent, $3 \times 1 \mathrm{~mm}$, disc persistent, not accrescent, $0.8 \times 0.8 \mathrm{~mm}$, fruit surface convex, with two adjacent parallel longitudinal crests $0.4 \mathrm{~mm}$ wide, $0.6 \mathrm{~mm}$ apart along their length, forming a longitudinal groove from apex to base between the two crests. Pyrene not seen.

\section{Distribution, habitat}

Java (Indonesia) and Borneo (Brunei). Lowland evergreen forest.

\section{Remarks}

The lectotype specimen of Chassalia blumeana [L 0057738] was collected in Java. The infructescence of the lectotype specimen is a 3 -branched compound cyme with branches and rachis $2-4 \mathrm{~mm}$ long. The branches and rachis remain short during fruit maturation. The exact distribution of this species in Borneo 
is unknown. The specimen most similar to the lectotype found in Borneo from the Kew herbarium is: BRUNEI • Bang Dangung, Bila pinggan group; 12 Jul. 1993; Jay H. Bernstein JHB 405; K!.

Chassalia blumeana differs from other species by the base of the inflorescence peduncle not having bracts, and by having the branches and rachis of the infructescence less than $5 \mathrm{~mm}$ long. It differs from Chassalia ramosa T.Y.Yu sp. nov. by having just 1 flowering branch, rather than two or more per stem.

Chassalia blumeana may be the taxonomically most difficult species among all Asian species of Chassalia. Most of the specimens of Chassalia from Borneo were previously identified as Cephaelis psychotrioides (=Chassalia psychotriformis) and Cephaelis stipulacea (synonym of Chassalia blumeana). These specimens contain a wide range of morphological variation. The lectotype specimen of Chassalia blumeana from Java shows that this species seems to have 1 peduncle and 3 capitula on highly reduced partial peduncles less than $0.5 \mathrm{~cm}$ long. This makes the inflorescence look as though it is one big capitulum. The description in the protologue indicates that this species is distributed from West to Central Java (Blume 1826-1827). Additional information is provided by the description and illustration of Valeton (1913a). These highlight the short partial peduncles (5-10 $\mathrm{mm}$ long) which are slightly longer then the partial peduncle of the lectotype specimen. Valeton (1913a) recorded it as distributed from Java and in Borneo from northwest Indonesian Borneo to southwest Malaysian Borneo (Kuching). In this survey, specimens which appear to be a reasonable match for the type specimen of $C$. blumeana have been found in both Indonesian Borneo and Malaysian Borneo (Kuching), as well as Brunei. However, several specimens from west Sarawak to Sabah seem to share similarity with the typical C. blumeana but also vary somewhat from this species. Therefore, the delimitation of $C$. blumeana with similar specimens from Borneo still needs further study.

Chassalia calamus T.Y.Yu sp. nov. urn:Isid:ipni.org:names:77215404-1

Figs $8-9$

\section{Diagnosis}

Differs from other species in having a strong and thick, but hollow, stem 5-12 mm diameter (vs stem solid, ca 3-5 mm diameter); leaves large 17-33 $\times 5.5-12 \mathrm{~cm}$ (in most species except $C$. atropurpurea sp. nov. and $C$. involucrata sp. nov. not reaching these dimensions); inflorescence usually very short with peduncle very short or absent, $(<0.1-) 0.5-3.5 \mathrm{~cm}$ (in other species usually exceeding $3.5 \mathrm{~cm}$ long); secondary peduncle usually very short to absent making the inflorescence highly compact.

\section{Etymology}

The epithet, treated as a noun in apposition, is derived from the Latin 'calamus', a reed or more generally a hollow-stemmed plant. The name refers to the hollow stem, unusual in Bornean species of Chassalia.

\section{Type}

MALAYSIA - Borneo, Sabah • Nabawan, Sungai Millian, along stream-side; 18 Nov. 1986; Asik Mantor SAN 118683; holotype: K[K001129723]!; isotype: SAN.

\section{Additional material}

MALAYSIA - Borneo, Sabah - Keningau, Crocker range area, mile 16, Kimanis Road; 23 Aug. 1986; Sumbing Jimpin SAN 120566; K!, KEP!, SAN • Tambunan, Sunsuron Km 54 Jalan Tambunan/ Penampang; alt. 1400 m; 24 Aug. 1989; Fidilis. K. SAN 127894; K!, SAN • Ranau, Ulu Tungud Forest Reserve, Gunung Monkobo Expedition; 552'45" N, 116 55'28" E; alt. 343 m; Saw L.G. SAN 146079; K!, SAN • Tambunan, Rafflesia Information Centre, Hill Dipterocarp Forest; 2 Sep. 2001; J.T. Pereira et al. JTP 845; K!, SAN • Pandewan, Sungai Pamentarian; 25 Feb. 1987; Sumbing Jimpin SAN 120057; $\mathrm{K}$ !, SAN. 


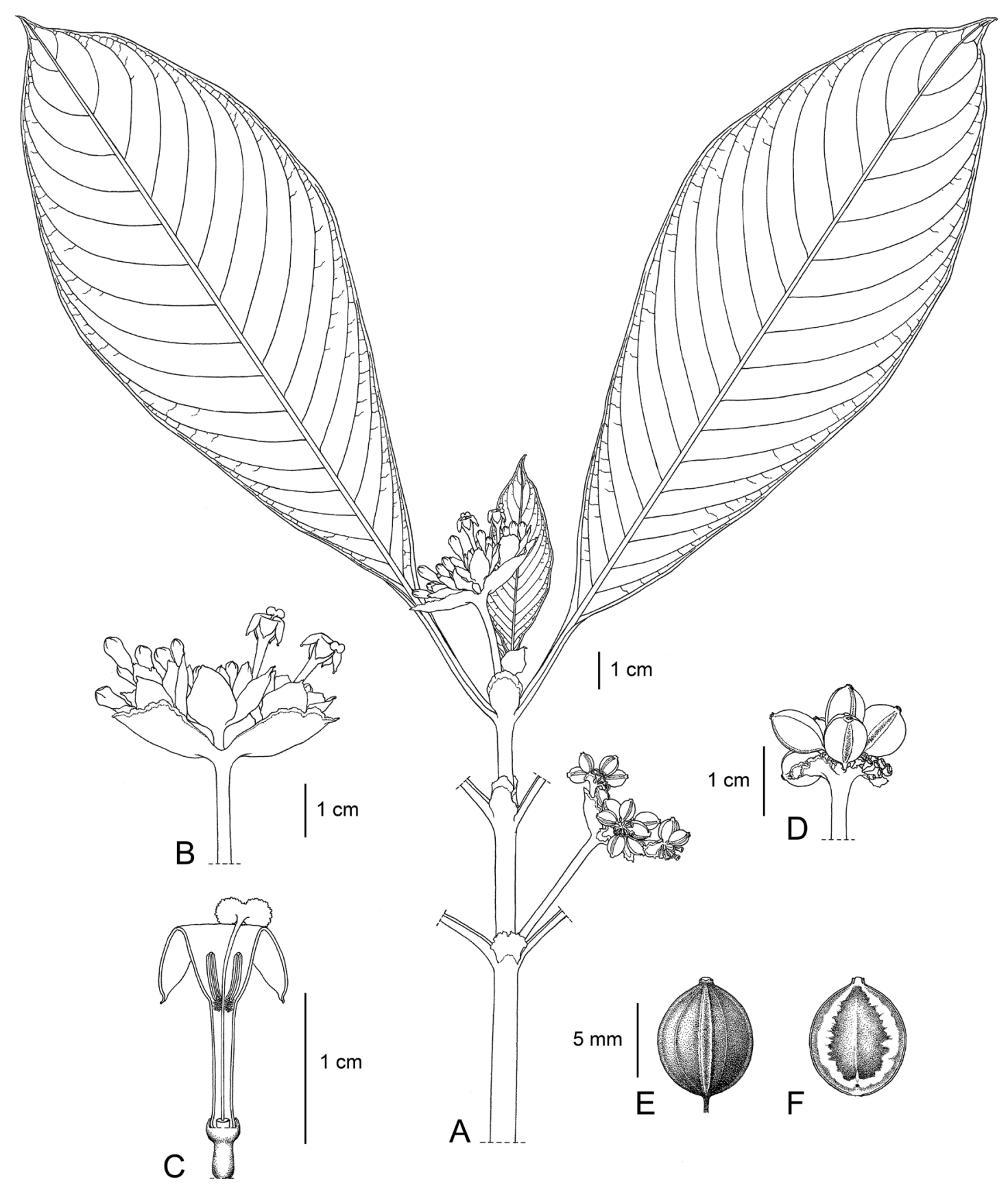

Chassalia calamus T.Y.Yu

Fig. 8. Chassalia calamus T.Y.Yu sp. nov. A. Flowering shoot. B. Inflorescence. C. Longitudinal view of flower showing stamens, band of hairs, stigma, style, disc, calyx and hypanthium. D. Part of infructescence. E. Dry fruit. F. Pyrene ventral surface. From Asik Mantor SAN 118683. Drawn by T.Y. Yu. 


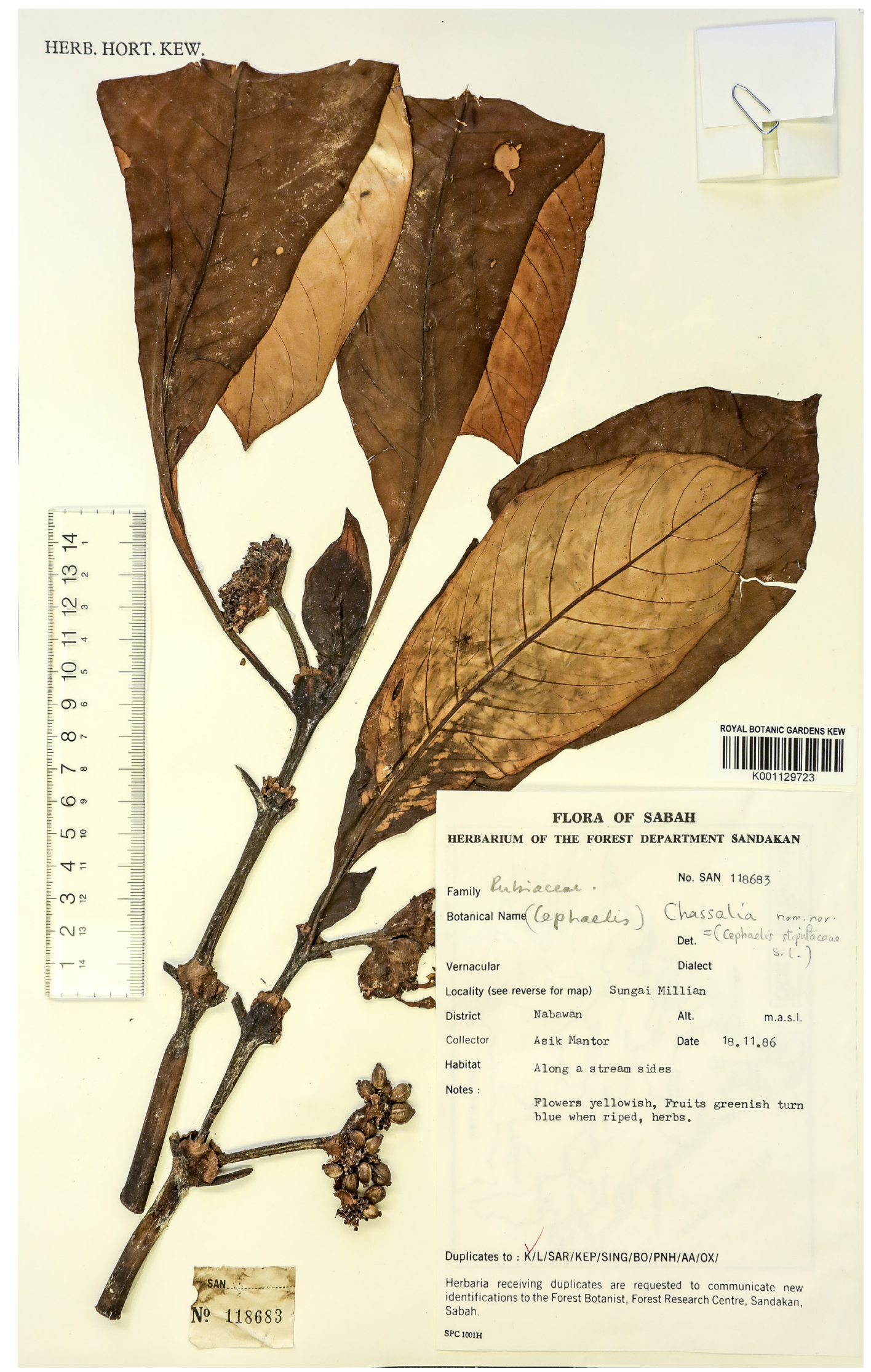

Fig. 9. Holotype of Chassalia calamus T.Y.Yu sp. nov. (Asik Mantor SAN 118683). 


\section{Description}

Herb, shrub to small treelet, (0.5-)1-1.5 m tall, glabrous. Stem terete, flattened and slightly canaliculate, or sometimes deeply canaliculate, hollow. Lower internodes $3-6 \times 0.5-1.2 \mathrm{~cm}$, surface usually covered by pustules, internode of flowering stems shorter, $1-2.5 \times 0.3-0.8 \mathrm{~cm}$. Leave-blades elliptic to broadly lanceolate, very large, $17-33 \times 5.5-12 \mathrm{~cm}$, midrib raised both adaxially and abaxially, secondary veins 14-18 on each side, petiole flat, canaliculate, $(0.5-) 1.5-5 \mathrm{~cm}$. Stipule large, not sheathing, broadly flabellate, $0.8-1.2 \times 0.8-2 \mathrm{~cm}$, apex usually irregular. Inflorescence a compound cyme, peduncle very short to absent, $(<0.1-) 0.5-3.5 \mathrm{~cm}$, rachis and branches usually very short to absent, $(<0.1-) 1.5 \mathrm{~cm}$. Bracts $8-10$ in each capitulum, pale green, $7-8 \times 3-4 \mathrm{~mm}$. Flowers 14-20 in each capitulum, pedicel short or absent, hypanthium ellipsoid, $1.5 \times 1.5-2 \mathrm{~mm}$, calyx tube slightly curved, $1.5-1.8 \times 0.5 \mathrm{~mm}$ in total, corolla whitish green, cream-white or yellowish white, $10-12 \times 0.5 \mathrm{~mm}$, corolla tube $0.5 \mathrm{~mm}$ wide at base, broadening in distal third to $2.5 \mathrm{~mm}$ wide; corolla lobes triangular, 2-2.5 $\times 1.5 \mathrm{~mm}$. Disc cylindric, $0.8 \times 0.5 \mathrm{~mm}$. Stamens $2.2 \times 0.2 \mathrm{~mm}$, anthers placed at the mouth of corolla, filament insertion $8 \mathrm{~mm}$ from base of corolla, filament very short, less than $0.1 \mathrm{~mm}$ long, band of hairs $0.5-1 \mathrm{~mm}$ wide, at base of stamens $8 \mathrm{~mm}$ from mouth of corolla tube, hairs erect, colourless, $0.1-0.2 \mathrm{~mm}$ long. Style $1.5 \mathrm{~cm}$ long. Fruits ellipsoid, 5-8 $\times 4-5 \times 3.5-4 \mathrm{~mm}$, pedicel of fruit persistent, not accrescent or slightly accrescent, 3-4 mm long. Pyrenes plano-convex, dorsal surface convex, with two adjacent parallel longitudinal crests, each $0.1 \times 0.25 \mathrm{~mm}$, curved, $0.4 \mathrm{~mm}$ apart along their length, forming a longitudinal groove from apex to base between the two crests; ventral surface concave, central part slightly elevated, margin with an endocarpal outgrowth $0.7 \mathrm{~mm}$ wide, with a groove between the edge of endocarp and endocarpal outgrowth $0.2 \mathrm{~mm}$ wide. Raphal opening at base of the endocarpal outgrowth, round, $0.2 \mathrm{~mm}$ in diameter, $0.2-0.3 \mathrm{~mm}$ from the edge of the pyrene wall, apex with a bony spine, spine triangular, erect, $0.5 \times 0.2 \mathrm{~mm}$. PGS not detected. Seeds light brown, hemi-ellipsoid, slightly crested at central part of dorsal side, $4.5 \times 0.7 \mathrm{~mm}$.

\section{Distribution, habitat}

Borneo: Malaysia, Sabah, around Ranau and Tambunan. Hill forest, stream valley, rocky moist slopes, alt. $125-1300 \mathrm{~m}$.

Chassalia chewii T.Y.Yu sp. nov. urn:lsid:ipni.org:names:77215405-1

Figs 10-11

\section{Diagnosis}

Differs from all other Kinabalu species of Chassalia in having elliptic to ovate leaves, in the first internode of flowering branches usually very short (1.5-4 cm long), in having 3 peduncles, the main rachis with 3 capitula, and in the bracts of the capitulum being so big that usually they cover the flower buds.

\section{Etymology}

Named after Chew Wee Lek who was the collector of most specimens of this new species.

\section{Type}

MALAYSIA - Borneo, Sabah • Mt Kinabalu, Ulu Langanani, Sungai Mamut; 604' N, $116^{\circ} 40.44^{\prime}$ E; alt. 4000 ft; 4 Aug. 1961; fl.; W.L. Chew, E.J.H. Corner \& A. Stainton 1226; holotype: K[K001129712]!.

\section{Additional material}

MALAYSIA - Borneo, Sabah • Mt Kinabalu, Ulu Liwagu and Ulu Mesilau; $6^{\circ} 00^{\prime}$ N, about $116^{\circ} 35^{\prime}$ E; alt. 5000 ft; 6 Sep. 1961; fl.; W.L. Chew, E.J.H. Corner \& A. Stainton 2807; K! • Mt Kinabalu, Ulu 


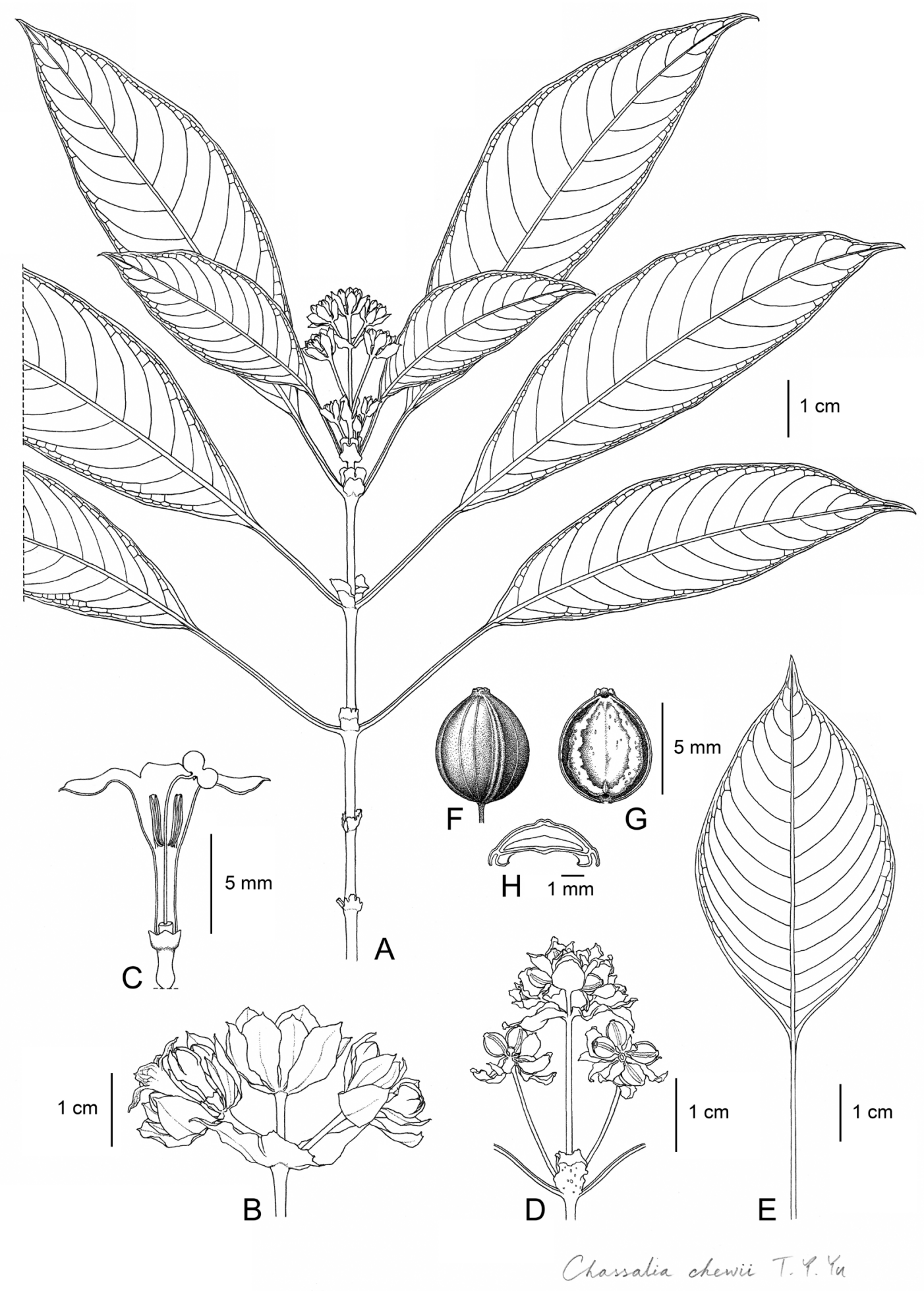

Fig. 10. Chassalia chewii T.Y.Yu sp. nov. A. Flowering shoot. B. Inflorescence showing capitulum, bracts and flowers. C. Longitudinal view of flower showing stamens, band of hairs, stigma, style, disc, calyx and hypanthium. D. Infructescences. E. Leaf showing another shape of leaf-blade. F. Dry fruit. G. Pyrene ventral surface. H. Pyrene transection. A-C from W.L. Chew, E.J.H. Corner \& A. Stainton 1226; D-H from $J \&$ M.S. Clemens 30335. Drawn by T.Y. Yu. 


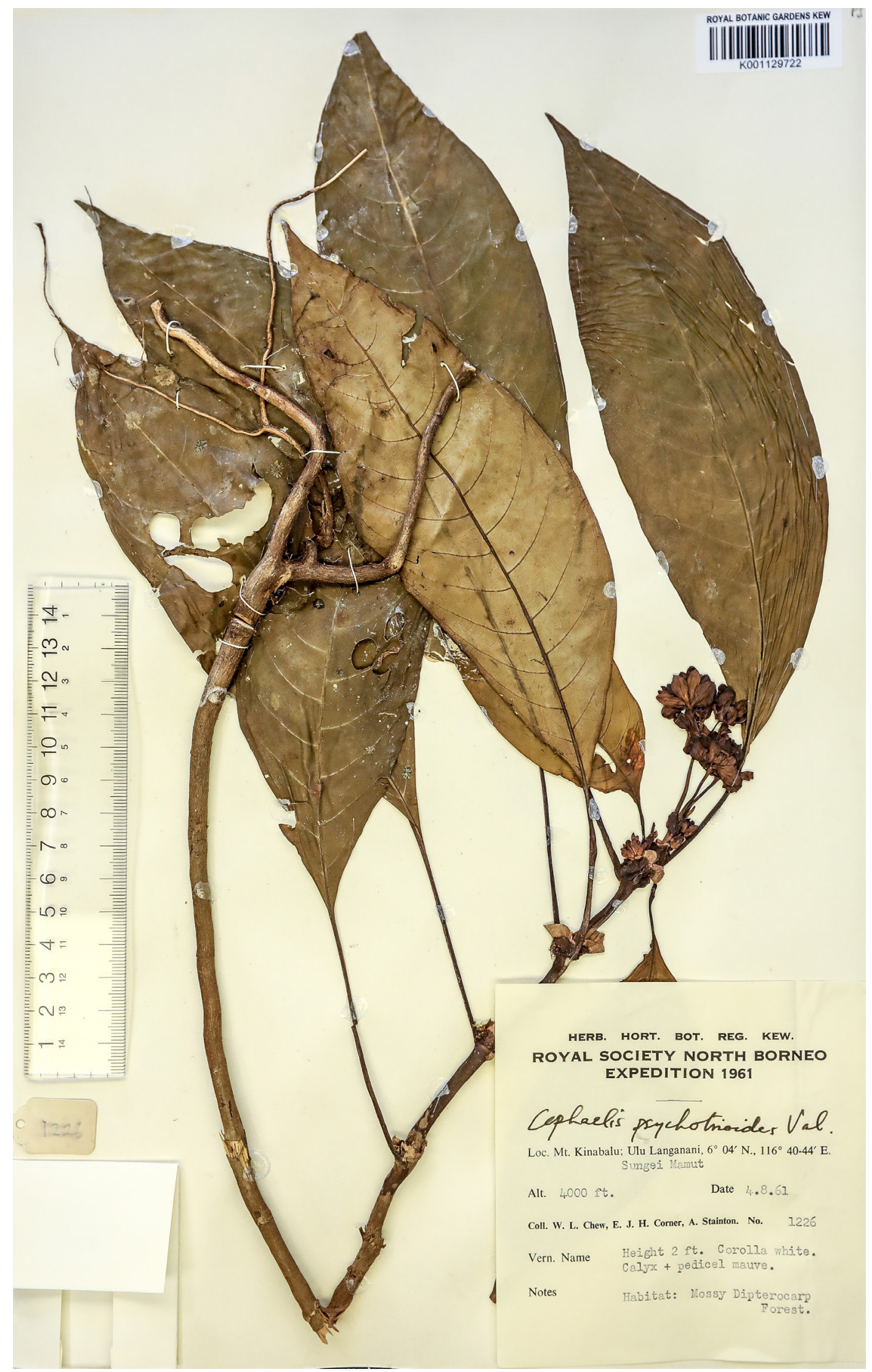

Fig. 11. Holotype of Chassalia chewii T.Y.Yu sp. nov. (W.L. Chew, E.J.H. Corner \& A. Stainton 1226). 
Liwagu and Ulu Mesilau; $6^{\circ} 00^{\prime} \mathrm{N}$, about 116 35' E; alt. 5000 ft; 22 Aug. 1961; fl. ; W.L. Chew, E.J.H. Corner \& A. tainton 1948; K! • Mount Kinabalu, Dallas; 3000 ft; 1 Dec. 1931; fr.; J. \& M.S. Clemens 27341; K! • Mount Kinabalu, Tenompok; 5000 ft; 12-23 Feb. 1932; fr.; J. \& M.S. Clemens 30336; K! • Mt Kinabalu, Tenompok; 5000 feet; 19 Feb. 1932; fr.; J\& M.S. Clemens 30335; K! • Mt Kinabalu, Ulu Liwagu and Ulu Mesilau; 6 Sept. 1961; fr.; W.L. Chew, E.J.H. Corner \& A. Stainton 2804; K!.

\section{Description}

Herb to small treelet, $0.4-0.9 \mathrm{~m}$ tall, apparently unbranched, glabrous. Lower internodes terete, $2.5-4.5(-7.5) \times 0.3-0.5 \mathrm{~cm}$, upper internodes usually drying flattened, strongly canaliculate, slightly broadened at apex, 1.5-4 cm long, base 2-4 mm wide, apex 3-5 mm wide, flowering internodes sometimes highly reduced, $0.5-1.5 \mathrm{~cm}$ long. Leaf-blades ovate to elliptic, $11-16(-21) \times 3-6.5 \mathrm{~cm}$, margin entire, apex acute to acuminate, acumen $1-1.5 \mathrm{~cm}$, base cuneate; midrib slightly raised above, domatia absent; secondary nerves 10-12 on each side of the midrib, prominent above; tertiary nerves not visible. Petiole flattened, canaliculate, $(1.5-) 2-6.5 \mathrm{~cm} \times 0.8-1.5 \mathrm{~mm}$. Stipule not sheathing, broadly flabellate, $0.5-1.2 \times 0.8-1.8 \mathrm{~cm}$, margin entire, apex usually broken. Inflorescences compound cymose, $3.5-5.5 \mathrm{~cm}$ long; peduncle very short to absent; first branches slightly flattened distally, $25 \times 1 \mathrm{~mm}$; rachis 4-4.5 cm long; second branches of rachis cymose, $15-20 \times 1 \mathrm{~mm}$; bracts of second branches $8-10 \times 4 \mathrm{~mm}$, exceeding the flowers and fruits. Flowers sessile in terminal clusters. Hypanthium obovoid, glabrous inside and out, $2-3 \mathrm{~mm}$ in total; sepals 5 , each broadly triangular, $0.5 \times 1 \mathrm{~mm}$. Corolla cream white, tube $7-8 \mathrm{~mm}$ long, broadening from midway to top, lower part $1.5 \mathrm{~mm}$ wide, apex $5 \mathrm{~mm}$ wide; lobes triangular, 3.5-4 × 3-4 mm, apex acute or apiculate. Stamens $2.3-2.5 \mathrm{~mm}$ long, with short spur $0.2 \mathrm{~mm}$ long; filaments flat and short, mostly hidden under anthers, $0.2-0.3 \mathrm{~mm}$ long. Style $7-8 \mathrm{~mm}$ long, slightly exserted out of corolla tube; stigma flat and large, $1.5 \times 3-3.5 \mathrm{~mm}$, bilobed, with a slightly raised margin less than $0.5 \mathrm{~mm}$ long, centre slightly hollowed. Disc conspicuous, cylindrical with a flat top, $0.5 \times 1 \mathrm{~mm}$. Fruit green maturing blue, deep brown when dry, ovoid to ellipsoid, 5-6 $\times$ 4-5 mm, junction between the two pyrenes slightly grooved, calyx persistent, lobes $5,0.2 \times 0.5 \mathrm{~mm}$. Pyrenes plano-convex, dorsal surface convex, with two adjacent parallel longitudinal crests, each $0.2-$ $0.3 \mathrm{~mm}$ wide, curved, $0.4-0.5 \mathrm{~mm}$ apart along their length, forming a longitudinal groove from apex to base between the two crests; ventral surface concave, central part slightly elevated, margin with an endocarpal outgrowth $0.8-1.0 \mathrm{~mm}$ wide, with a groove between the edge of endocarp and endocarpal outgrowth $0.2-0.4 \mathrm{~mm}$ wide. Raphal opening at base of the endocarpal outgrowth, round, $0.2 \mathrm{~mm}$ long, $0.2-0.3 \mathrm{~mm}$ from the edge of the pyrene wall, apex with a bony spine, spine triangular, erect, $0.8-1 \times$ $0.2 \mathrm{~mm}$. PGS not detected. Seed brown, hemi-ellipsoid, slightly crested at central part of dorsal side, $0.5 \times 4 \mathrm{~mm}$, endosperm at central part of the seed, $0.2-0.3 \mathrm{~mm}$ wide.

\section{Distribution, habitat}

Borneo: Malaysia, Sabah, around Mount Kinabalu. Lower montane forest, alt. 900-1500 m.

\section{Chassalia curviflora (Wall.) Thwaites}

Enumeratio Plantarum Zeylaniae (2): 150 (Thwaites 1859). - Psychotria curviflora Wall. in Roxburgh, Flora indica 2: 167 (Roxburgh 1824). - Uragoga curviflora (Wall.) Kuntze, Revisio Generum Plantarum 1: 299 (Kuntze 1891b). - Type: MALAYSIA • Penang; 1819; W. Jack s.n. [EIC 8360A]; hololectotype: K-W[K001125306]!, designated at the first step by Deb \& Krishna (1983: 221) and at the second step by Turner (2019: 397).

Psychotria lurida Blume, Bijdragen tot de flora van Nederlandsch Indië 16: 959 (Blume 1826). Zwaardekronia lurida (Blume) Korth., Nederlandsch Kruidkundig Archief 2 (2): 252 (Korthals 1851). - Chassalia lurida (Blume) Miq., Flora van Nederlandsch Indië 2 (2): 282 (Miquel 1857). 
- Chassalia curviflora var. lurida (Blume) Hochr., Candollea 5: 270 (Hochreutiner 1934). - Type: JAVA • C.L. Blume 2270; hololectotype: L[L.2950785], designated by Turner (2019: 397).

Chassalia chartacea Craib, Bulletin of Miscellaneous Information, Kew 1931: 279 (Craib 1931). Type: THAILAND • Surat, Yanyao; 21 Feb. 1930; A.F.G. Kerr 18175; holotype: K[K000761880]! [K001129592]! (2 sheets); isotype: BM[BM000945616].

For a more extensive synonymy see Turner (2019).

\section{Distribution, habitat}

India to the Philippines. Lowland evergreen forest.

\section{Remarks}

Chassalia curviflora is taken here as a single widespread (India to the Philippines) and variable species. Revision of this complex was beyond the scope of the present study, and only a single entity is keyed out above for Borneo.

Chassalia involucrata T.Y.Yu sp. nov. urn:lsid:ipni.org:names:77215406-1

Fig. 12-13

\section{Diagnosis}

Differs from other species of Chassalia in Borneo in having large leaves up to $48 \mathrm{~cm}$ long and $15 \mathrm{~cm}$ wide (they are much smaller in other species), in the capitulum having outer and inner bracts up to $1.5 \mathrm{~cm}$ wide (broader than in any other species), in the infructescences usually persisting for a whole season until new inflorescences are produced (not soon disappearing after fruit maturity). Most similar to, but differing from, C. calamus sp. nov. in having bracts usually longer than the flower bud (not shorter), in having a longer peduncle, in having bigger leaves (to $48 \times 12 \mathrm{~cm}$, not to $33 \times 12 \mathrm{~cm}$ ) and more secondary veins (up to 26 on each side of the midrib, not $<18$ ), and in having longer $(4-14 \mathrm{~cm}$, not $<5 \mathrm{~cm}$ ) petioles.

\section{Etymology}

The epithet alludes to the involucrate bracts of rachis and capitulum, which are larger and more conspicuous than in other species of the genus in Borneo.

\section{Type}

BRUNEI - Temburong district, Kuala Belalong, Batu Apoi Forest Reserve, at the Sungai Engkiang River, towards the Sungai Belalong, below Pondok Engkiang; $115^{\circ} 09^{\prime}$ E, 433' N; 22 Nov. 1991; Carlo Hansen 1608; holotype: K[K001129724]!.

\section{Additional material}

BRUNEI • S. Belalong below Kuala Ropan; 11 Feb. 1959; P.S. Ashton BRUN 5227; BRUN, K!, SING!, BRUN • Temburong District, LZ 298, beside the Temburong River; 19 Sep. 1988; W.K. Wong WKM 484; K!, SING!.

MALAYSIA - Borneo, Sabah - Tambunan District, Crocker Range, Km 64 on Kota Kinabalu Tambunan Road; 546' N, $116^{\circ} 21^{\prime}$ W; alt. 1250 m; 11 Oct. 1983; John Beaman 7268; K!, MSC, UKMS. - Borneo, Sarawak $•$ Kuching District, $12^{\text {th }}$ mile Penrissen Road; 19 Sep. 1966; Banyeng ak Nudong et 


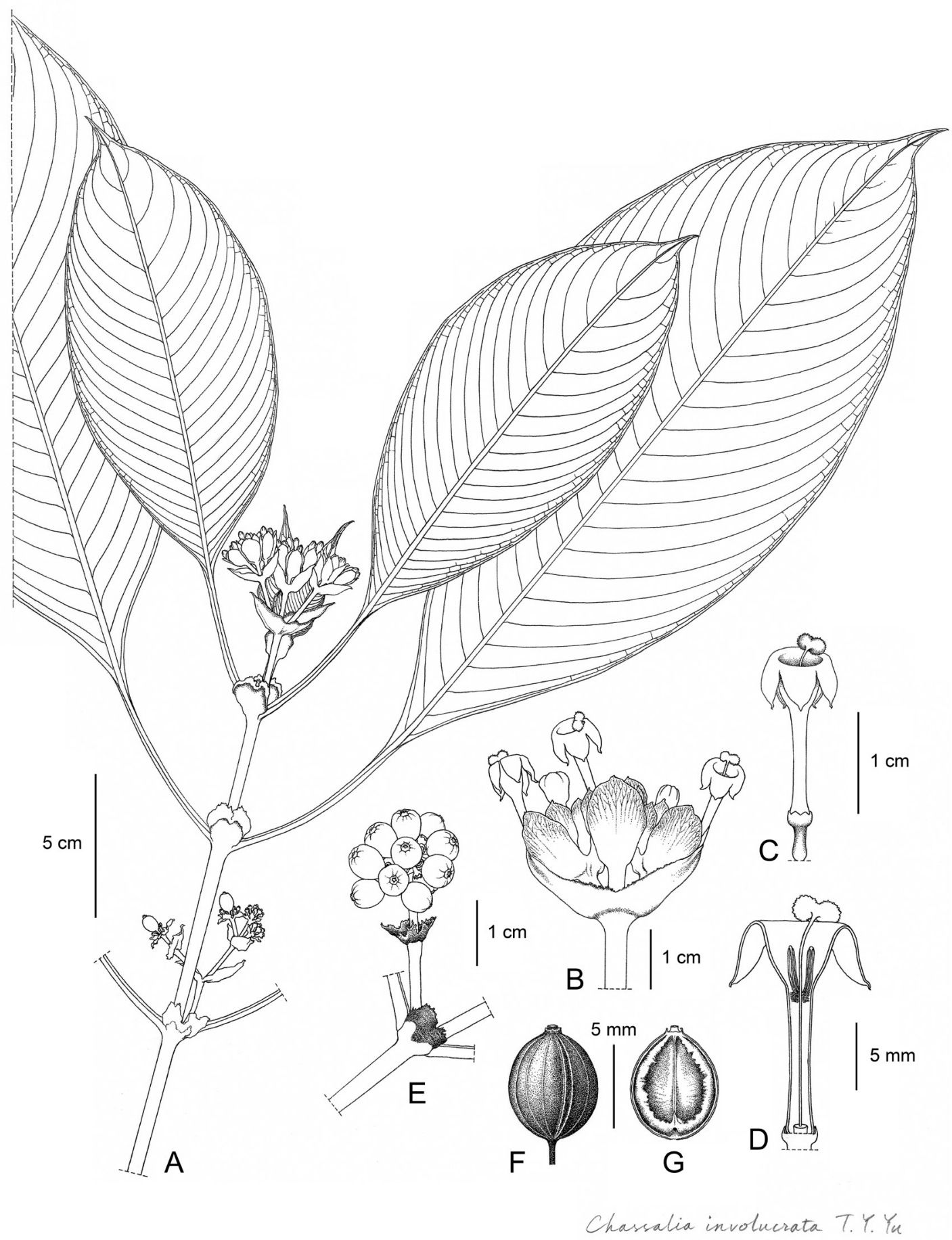

Fig. 12. Chassalia involucrata T.Y.Yu sp. nov. A. Flowering shoot. B. Inflorescence. C. Flower. D. Longitudinal view of corolla showing stamens, band of hairs, stigma, style and disc. E. Infructescence with stem node showing fresh fruit. F. Dry fruit. G. Pyrene ventral surface. A, C-D, F-G from Carlo Hansen 1608; B, E from photographs of living plants in Ulu Temburong National Park, Brunei, taken by Mr Y.W. Low. Drawn by T.Y. Yu. 


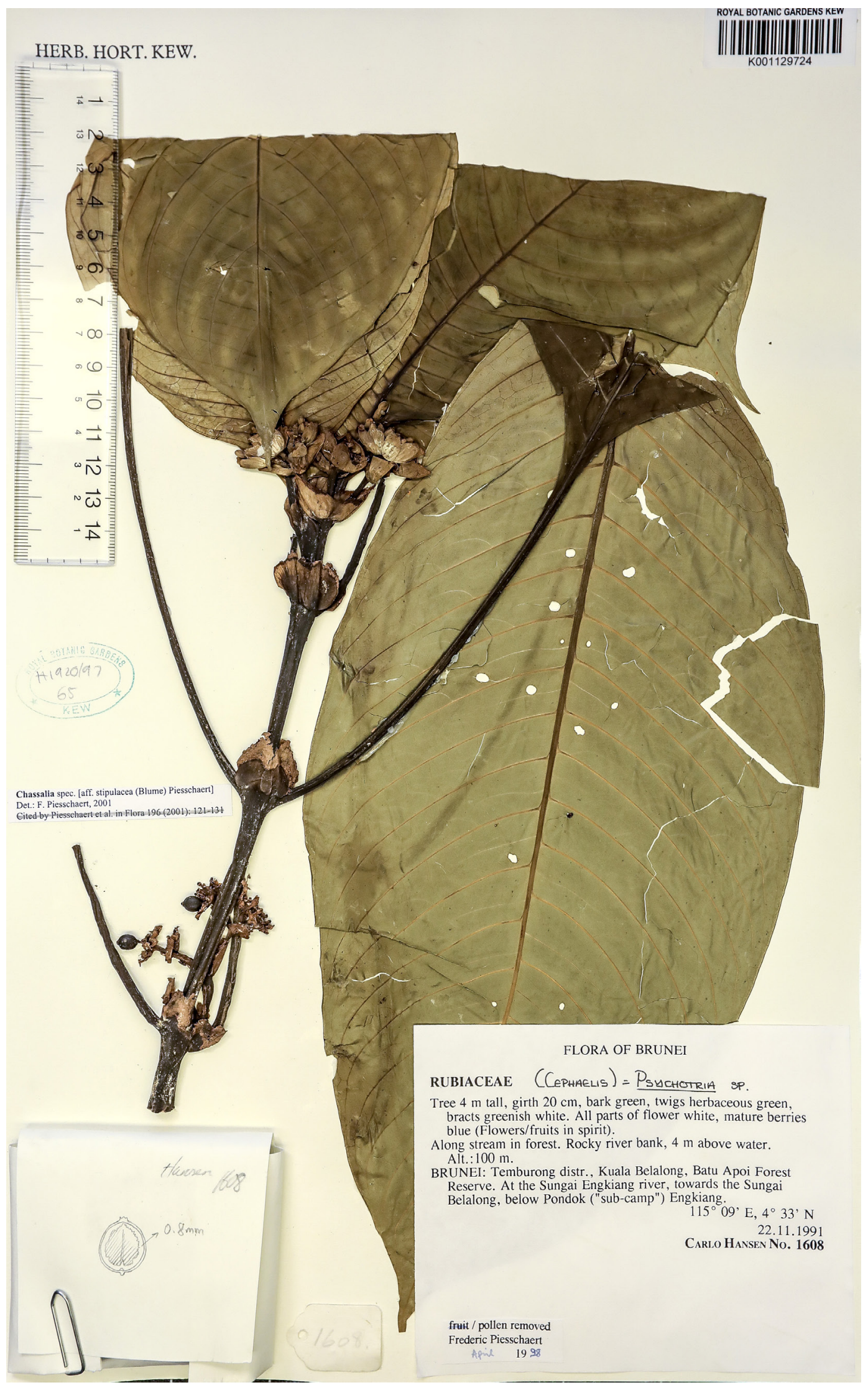

Fig. 13. Holotype of Chassalia involucrata T.Y.Yu sp. nov. (Carlo Hansen 1608). 
Benang ak Bubong, S 25474; A, BO, K!, L, SAN, SING, SAN, A, BO • Nanga Segera Base Camp, Ulu Engkari, Lanjak Entimau, Wildlife Sanctuary; 4 Jun. 1998; Kit Pearce, Awg Enjah S 78122; K!, KEP, L.

\section{Description}

Herb, semi-woody shrub to small tree, 1-4 m tall, glabrous. Stem strong and thick, $0.5-0.7 \mathrm{~cm}$ wide, slightly hollowed or not. Internodes $3-13.5 \mathrm{~cm}$ long, thick, sometimes slightly canaliculate, slightly broadening at apex. Stipules big, flabellate, 1-1.5 $\times 1-2 \mathrm{~cm}$, base usually divided into 2 parts. Leafblades large, broadly elliptic, 13-36 × 6-15 cm, midrib slightly raised both abaxially and adaxially, secondary veins 14-26 on each side, apex acuminate, acumen 5-18 mm long, base cuneate or attenuate, petiole long, 4-14 cm $\times 1.5-3 \mathrm{~mm}$. Peduncle (5-)20-25 $\times 1.5-3 \mathrm{~mm}$, bracts of rachis and first branches 2 , opposite, usually connate to half the length, each bract $1.5-2 \times 1-1.2 \mathrm{~cm}$, sheath $0.5-0.7 \times 2 \mathrm{~cm}$, rachis and secondary branches very short to absent, 2-6 mm long, bracts of secondary branches 2 , not sheathing, 12-15 × 10-12 mm, bracts of each capitulum elliptic, $8-12 \times 5-10 \mathrm{~mm}$. Flowers sessile in each capitulum, $16 \mathrm{~mm}$ long. Hypanthium $2 \times 0.5 \mathrm{~mm}$, calyx tube $0.5 \times 1.3 \mathrm{~mm}$, calyx lobes broadly triangular, $0.2 \times 0.5 \mathrm{~mm}$. Corolla tube $20 \times 1 \mathrm{~mm}$, broadening to $3 \mathrm{~mm}$ from midway, glabrous except inside corolla tube a band of hairs $2 \mathrm{~mm}$ wide at base of stamens, $7 \mathrm{~mm}$ from mouth of corolla tube, hairs erect, colourless, 0.1-0.2 mm long; corolla lobes 5, triangular, $4.5 \times 2 \mathrm{~mm}$. Stamens $2.5 \mathrm{~mm}$ long, slightly concave, base bifurcate, inserted $2 \mathrm{~mm}$ from mouth of corolla, filaments very short and broad, less than $0.1 \mathrm{~mm}$ long. Style probably exserted, stigma bilobed, lobes orbiculate, $1 \times 0.8 \mathrm{~mm}$. Disc cylindric, $1 \times 1 \mathrm{~mm}$, apex flat. Fruit sessile, ellipsoid, $7 \times 5 \times 4 \mathrm{~mm}$, ripening blue, calyx persistent, not accrescent, $0.5 \times 1.5 \mathrm{~mm}$, disc persistent, not accrescent, $0.7 \times 0.7 \mathrm{~mm}$. Pyrene plano-convex, $6 \times$ $5 \times 2 \mathrm{~mm}$, dorsal surface convex, with two adjacent parallel longitudinal crests, $0.4 \mathrm{~mm}$ wide, $0.4 \mathrm{~mm}$ apart along their length, forming a longitudinal groove from apex to base between the two crests; ventral surface concave, central part slightly elevated, margin with an endocarpal outgrowth $0.5-0.8 \mathrm{~mm}$ wide, with a groove between the edge of endocarp and endocarpal outgrowth $0.2 \mathrm{~mm}$ wide. Raphal opening at base of the endocarpal outgrowth, round, $0.1 \mathrm{~mm}$ in diameter, $0.5 \mathrm{~mm}$ from the edge of the pyrene wall, apex with a bony spine, spine triangular, erect, $0.5 \times 0.2 \mathrm{~mm}$. PGS not detected. Seed light brown, hemi-ellipsoid, $0.5 \times 5 \mathrm{~mm}$, longitudinally slightly crested at midline of dorsal surface, endosperm not detected.

\section{Distribution, habitat}

Borneo: Malaysia, Sarawak, Sabah; Brunei. River banks in lowland forest, alt. 100-350(-1250) m.

\section{Chassalia javanica (Blume) I.M.Turner}

Feddes Repertorium 130: 398 (Turner 2019). - Coffea javanica Blume, Catalogus van eenige der merkwaardigste zoo in-als uit-heemsche gewassen, te vinden in 's Lands Plantentuin te Buitenzorg opgemaakt door C. L. Blume, M.D., Directeur van voorz. tuin: 46 (Blume 1823). - Chiococca javanica (Blume) Blume, Bijdragen tot de flora van Nederlandsch Indië 16: 958 (Blume 1826). - Proscephaleium javanicum (Blume) Korth., Nederlandsch Kruidkundige Archief 2 (2): 248 (Korthals 1851). - Type: INDONESIA • Java, Tjapus; C.L. Blume s.n.; hololectotype: L[L0057991], designated by Turner (2019: 398).

\section{Additional material}

MALAYSIA • Borneo, Gommisi Kap, Genderen Stort, G. Djempanga; Aug. 1912; Amdjah 729; K! - Borneo, Sarawak, Bintulu, Sungai Penyilam, Pengkalan Resam; 1 Oct. 2006; Julia S., Tan H.S., Malcom D., Rantai J. et al. S 97155; K!, SAR. 


\section{Description}

Epiphytic shrub, glabrous. Stem terete, slightly canaliculate when dry. Internodes broadening slightly at base and apex, $(0.5-) 2-4(-6) \mathrm{cm} \times 2-3 \mathrm{~mm}$. Leaf-blades obovate to elliptic, 9-17 $\times 2-4.5 \mathrm{~cm}$, apex acute to acuminate, acumen $5 \mathrm{~mm}$ long if acuminate, base truncate, midrib raised adaxially and abaxially, secondary nerves $8-11$ on each side of the midrib, petioles $0.5-3 \mathrm{~cm}$ long. Stipule broadly triangular, 4-5 $\times 5 \mathrm{~mm}$, sometimes bilobed when broken, margin with terminal colleters, inside with standard colleters $0.5-1 \mathrm{~mm}$ long. Inflorescence a compound cyme, $4.5-7 \mathrm{~cm}$ long, peduncle $0.8-4 \mathrm{~cm}$ long, internodes of rachis $0.5-1.5 \mathrm{~cm}$ long, each node of inflorescence including capitulum with 4 bracts, triangular, margin with teeth, 2 broader bracts $0.5-1.5 \times 0.5-1 \mathrm{~mm}, 2$ narrower bracts $1.5 \times 0.5 \mathrm{~mm}$. Open flowers not seen. Fruits narrowly ellipsoid, 5-6 $\times 4 \mathrm{~mm}$, with pedicels 5-6 mm long. Pyrene dorsal surface rough, with a central longitudinal groove $1.5-2 \mathrm{~mm}$ wide, pyrene ventral surface with a central groove $1.5-2 \mathrm{~mm}$ wide and a ridge at centre of the groove $0.5 \mathrm{~mm}$ wide and as high as the plane of the endocarpal outgrowth, the 2 grooves between endocarpal outgrowth and pyrene margin $0.1 \mathrm{~mm}$ wide or absent. Seed not seen.

\section{Distribution, habitat}

Malaysia, Borneo; Indonesia, Kalimantan, Java, Sumatra. Epiphytic in lowland to montane forest.

\section{Remarks}

Differs from other Asian species of Chassalia by usually being epiphytic, by having narrowly ellipsoid fruits only 5-6 mm long, pyrenes with dorsal surfaces bearing a longitudinal groove but without a crest, and ventral surfaces with only 1 ridge, reaching as high as the plane of the endocarpal outgrowth.

\section{Chassalia kinabaluensis T.Y.Yu sp. nov.}

urn:1sid:ipni.org:names:77215407-1

Figs $14-15$

\section{Diagnosis}

Similar to Chassalia atropurpurea sp. nov., differs in having green-brown, not dark purple stems, pedicels, midribs and inflorescence axes; in having a shorter peduncle, $3.5 \mathrm{~cm}$ long when flowering (not $3.5-6 \mathrm{~cm}$ long); differs also in having relatively long pedicels, $2-4 \mathrm{~mm}$ long (not subsessile or sessile).

\section{Etymology}

The epithet alludes to Mount Kinabalu to which the new species is endemic.

\section{Type}

MALAYSIA - Borneo, Sabah • Mount Kinabalu, head of Liawagu River Trail; alt. 1800-1900 m; $6^{\circ} 02^{\prime}$ N, 116³3' E; 23 Mar. 1995; John H. Beaman 11299; holotype: K[K001129712]!; isotypes: UNIMAS, IBEC.

\section{Additional material}

MALAYSIA - Borneo, Sabah • Tenompok, Mount Kinabalu; alt. 1500 m; Jun. 1932; J. \& M.S. Clemens 28169; K! • Mesilau River; alt. 1500 m; 27 Jan.1964; RSNB 4157; K! • Ranau, Tenompok F.R., Lower Montane Forest; 30 Aug. 2001; JTP 825; K! • along the East Mesilau River between Mt Kinabalu golf course site and Mesilau Cave; $6^{\circ} 03^{\prime}$ N, 116 ${ }^{\circ} 36^{\prime} \mathrm{W}$; alt. 1700-1900 m; 20 Dec. 1983; John H. Beaman 7977; K!, MSC, UKMS • Mt Kinabalu National Park, montane oak forest; alt. 1630 m; 27 May 1966; Ding Hou 227; K!, L. 


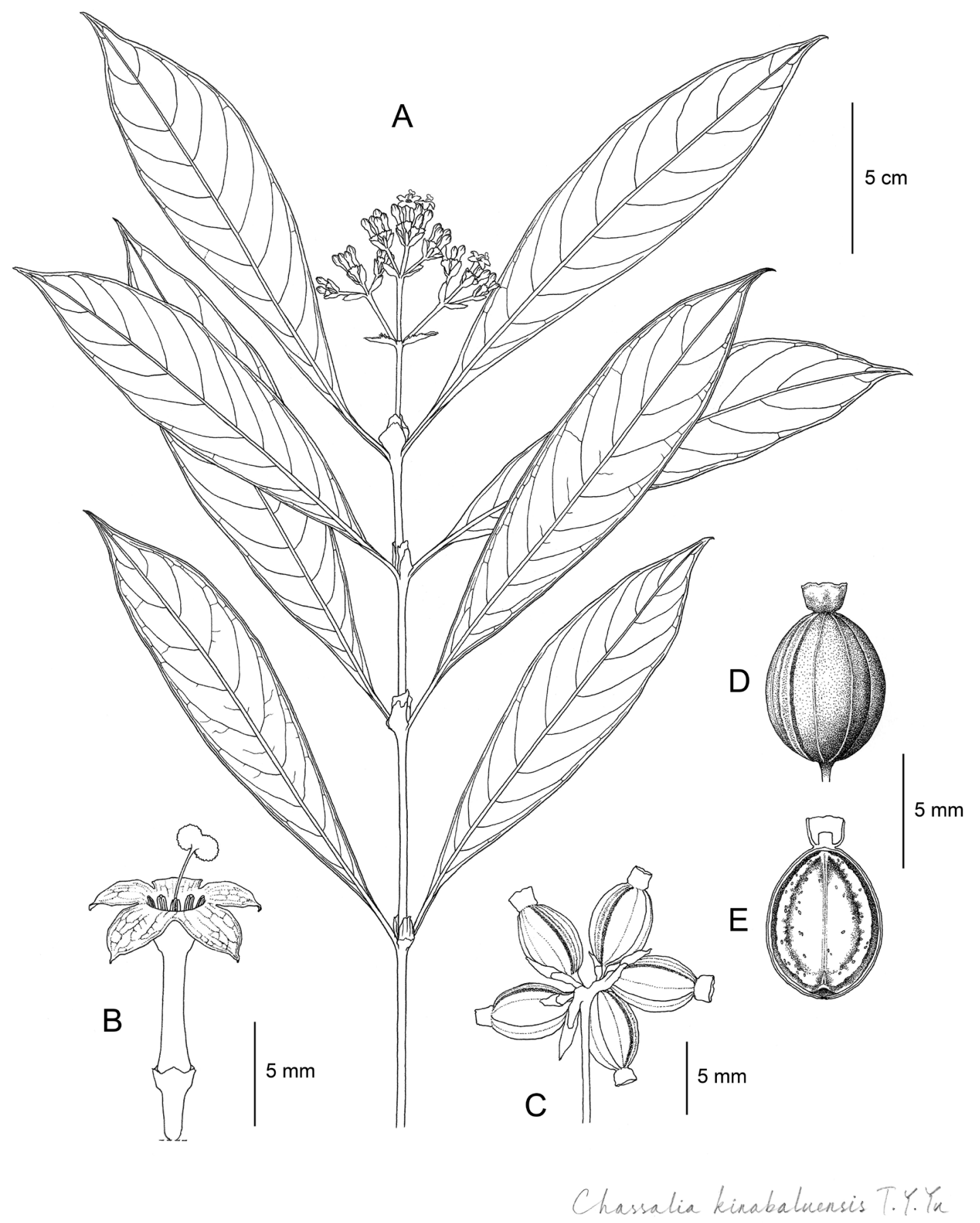

Fig. 14. Chassalia kinabaluensis T.Y.Yu sp. nov. A. Flowering shoot. B. Flower. C. Part of infructescence. D. Dry fruit. E. Pyrene ventral surface. From John H. Beaman 11299. Drawn by T.Y. Yu. 


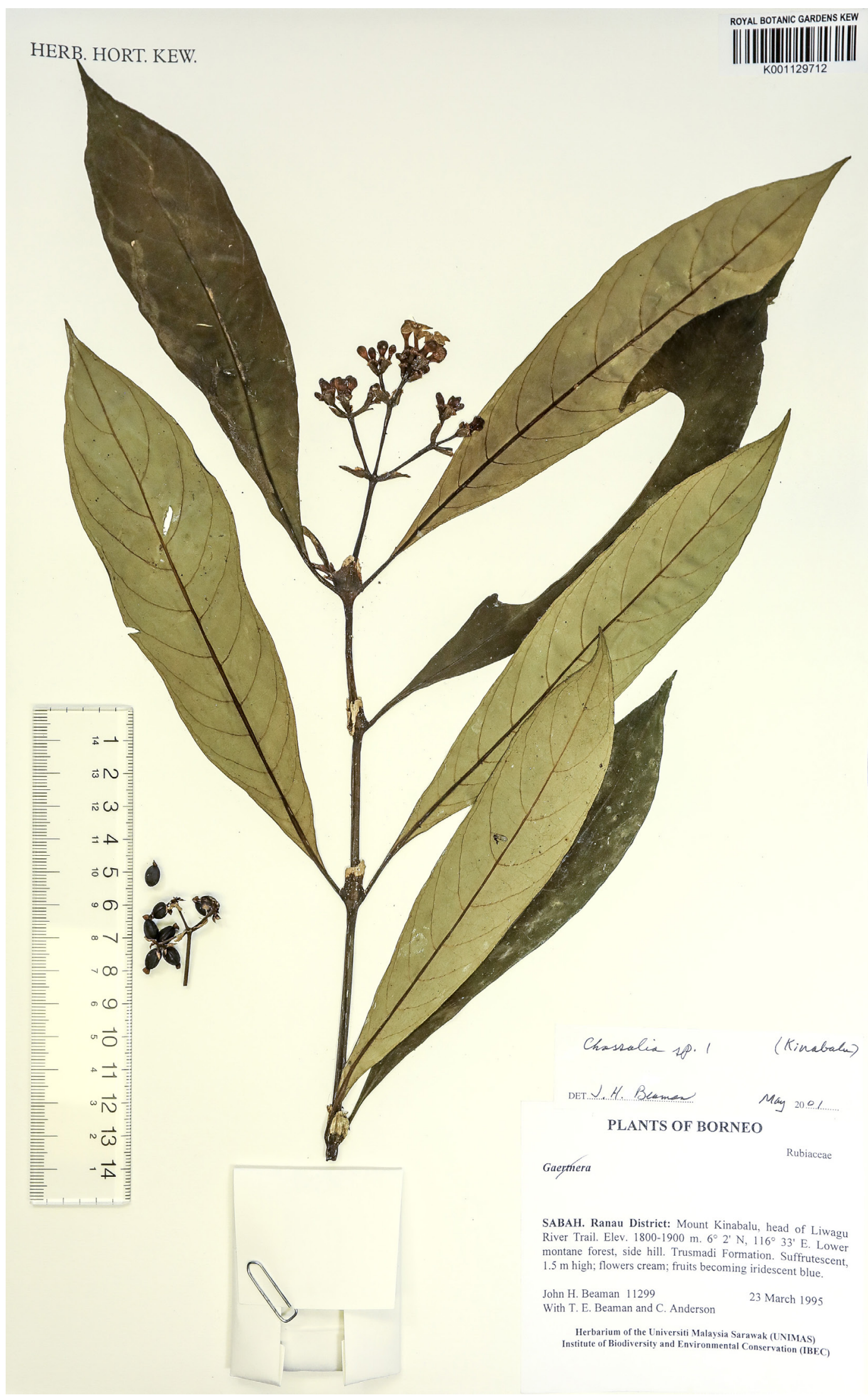

Fig. 15. Holotype of Chassalia kinabaluensis T.Y.Yu sp. nov. (John H. Beaman 11299). 


\section{Description}

Shrub to treelet, $0.5-0.9 \mathrm{~m}$ tall, glabrous, stems green-brown (also pedicels, midribs and inflorescence axes). Internodes from flowering branch (1-)2-5(-9.5) $\mathrm{cm} \times 2-4 \mathrm{~mm}$, lower internodes terete, upper internodes usually flattened, canaliculate, broadening at apex, base $2-4 \mathrm{~mm}$ wide, apex 3-5 $\mathrm{mm}$ wide. Leaf-blades narrowly elliptic to narrowly oblanceolate, $13-21.5 \times 3.5-5 \mathrm{~cm}$, margin entire, apex acute, base cuneate; midrib slightly raised above, domatia absent; secondary nerves $8-12$ on each side of the midrib, prominent above; tertiary nerves not visible. Petiole terete, sometimes canaliculate, usually slightly winged, $10-25 \times 1-2 \mathrm{~mm}$. Stipule not sheathing, broadly flabellate, $5-11 \times 8-10 \mathrm{~mm}$, apex usually broken. Inflorescence a compound cyme, 6-12 cm long; peduncle $3.5-6 \mathrm{~cm}$ long; bracts of first internode of rachis and first branches 2, triangular, flabellate or lanceolate, 3-12 $\times 1-3 \mathrm{~mm}$, sometimes with 2-3 teeth on the margin; first internode of rachis and first branches $4.5-8.5 \mathrm{~cm}$ long; second internode of rachis and second branches $2.5-4.5 \mathrm{~cm}$ long; bracts of capitulum oblong-obovate, $3-5 \times$ $2 \mathrm{~mm}$, apex rounded. Pedicel short, $2-4 \times 0.5 \mathrm{~mm}$. Flowers subsessile, usually 5 in each capitulum, 10-12 mm long, hypanthium 1-3 ×0.6-0.8 mm, calyx tube $0.3-1 \times 1-2.5 \mathrm{~mm}$, lobes $0.3 \times 0.4-0.5 \mathrm{~mm}$. Corolla cream white or purplish white, tube base narrow, $0.6-1.2 \mathrm{~mm}$ wide, broadening from midway, apex 3.5-4.5 mm wide, corolla lobes triangular, $2.5 \times 2 \mathrm{~mm}$. Fruits iridescent blue, ellipsoid, 7-8 $\times$ 4-5.5 mm, with pedicels $2-4 \mathrm{~mm}$ long. Pyrenes plano-convex, dorsal surface convex, with two adjacent parallel longitudinal crests, each $0.3 \mathrm{~mm}$ wide, curved, $0.3 \mathrm{~mm}$ apart along their length, forming a longitudinal groove from apex to base between the two crests; ventral surface concave, central part slightly elevated, margin with an endocarpal outgrowth $0.6 \mathrm{~mm}$ wide, with a groove between the edge of endocarp and endocarpal outgrowth $0.2-0.3 \mathrm{~mm}$ wide. Raphal opening at base of the endocarpal outgrowth, narrowly ovoid, $0.5 \times 0.2 \mathrm{~mm}, 0.2-0.3 \mathrm{~mm}$ from the edge of the pyrene wall, apex with a bony spine, spine triangular, erect, $0.5-0.7 \times 0.2-0.3 \mathrm{~mm}$. PGS not detected. Seed light brown, hemiellipsoid, slightly crested at central part of dorsal side, $0.3 \times 4 \mathrm{~mm}$, endosperm not detected.

\section{Distribution, habitat}

Borneo: Sabah, Mount Kinabalu (Kinabalu National Park), Lower montane forest, alt. 1100-1500 m.

Chassalia lancifolia T.Y.Yu sp. nov. urn:lsid:ipni.org:names:77215408-1

Figs 16-17

\section{Diagnosis}

Differs from other Kuching species (C. lancifolioides T.Y.Yu sp. nov. and C. macrocarpa T.Y.Yu sp. nov.) in having oblanceolate leaf-blades (not lanceolate), sessile inflorescences (peduncle inconspicuous), 4 thin bracts subtending the rachis with 2 longer bracts $10-12 \times 1-3 \mathrm{~mm}$ and 2 shorter bracts $3-5 \times$ $2 \mathrm{~mm}$, small capitular bracts 5-6 $\times 2-6 \mathrm{~mm}$, long corolla tube $10-18 \mathrm{~mm}$ long.

\section{Etymology}

Based on the unpublished name given to some specimens of 'Cephaelis lancifolius' by H.N. Ridley.

Type

MALAYSIA - Borneo, Sarawak • Matang; Jan. 1915; H.N. Ridley s.n.; holotype: K[K001129713]!.

\section{Additional material}

MALAYSIA - Borneo, Sarawak • Kuching; 16 Apr. 1893; G.D. Haviland 2998; K! • Munggu Unjam F.R.; 17 Oct. 1958; F.G. Browne 9663; K!, SING! • Kuching; 28 Feb. 1893; G.D. Haviland 2997; K!. 


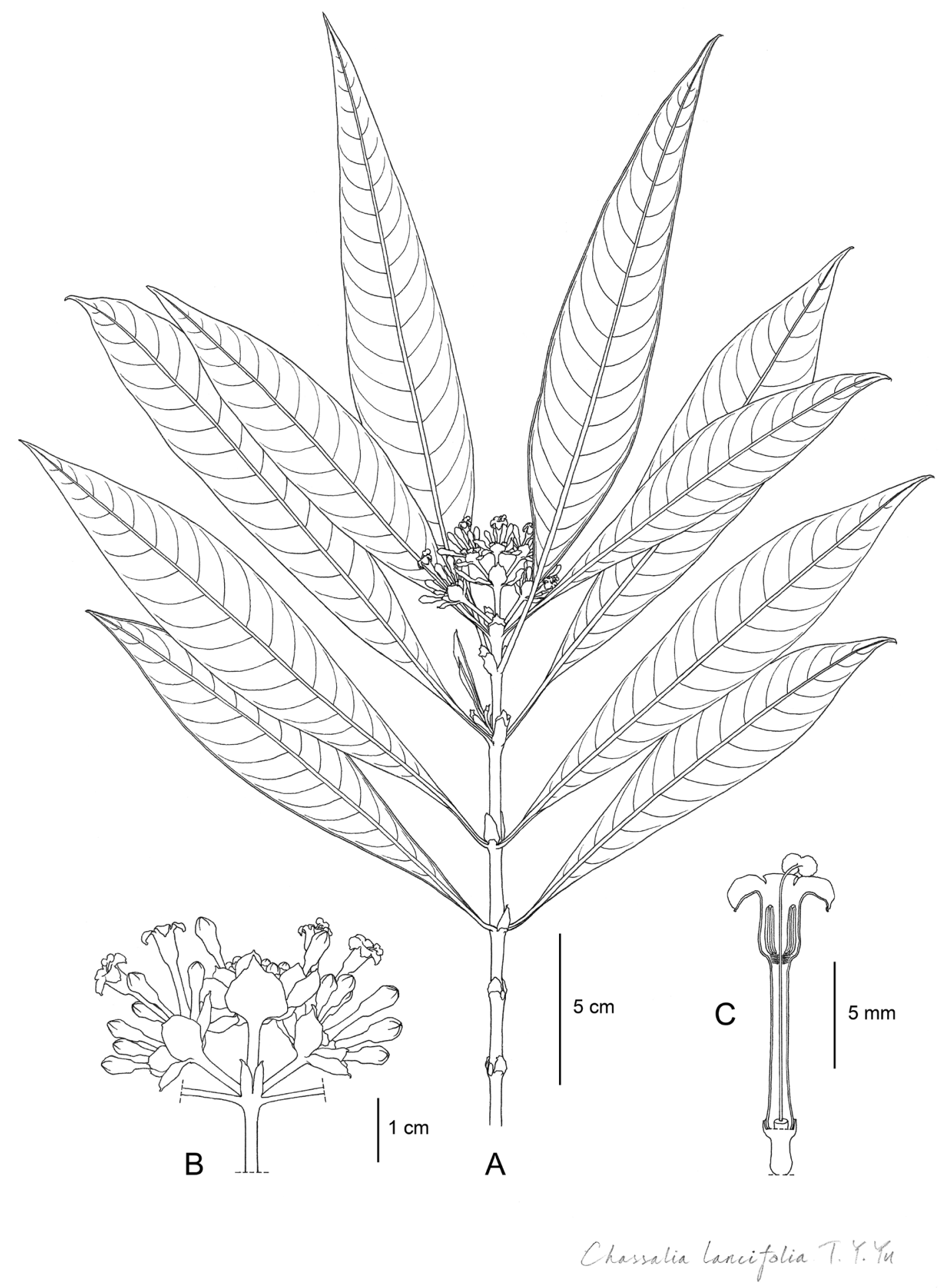

Fig. 16. Chassalia lancifolia T.Y.Yu sp. nov. A. Flowering shoot. B. Central branch of inflorescence. C. Longitudinal view of corolla showing stamens, band of hairs, stigma, style and disc. From H.N. Ridley s.n. (K001129713). Drawn by T.Y. Yu. 


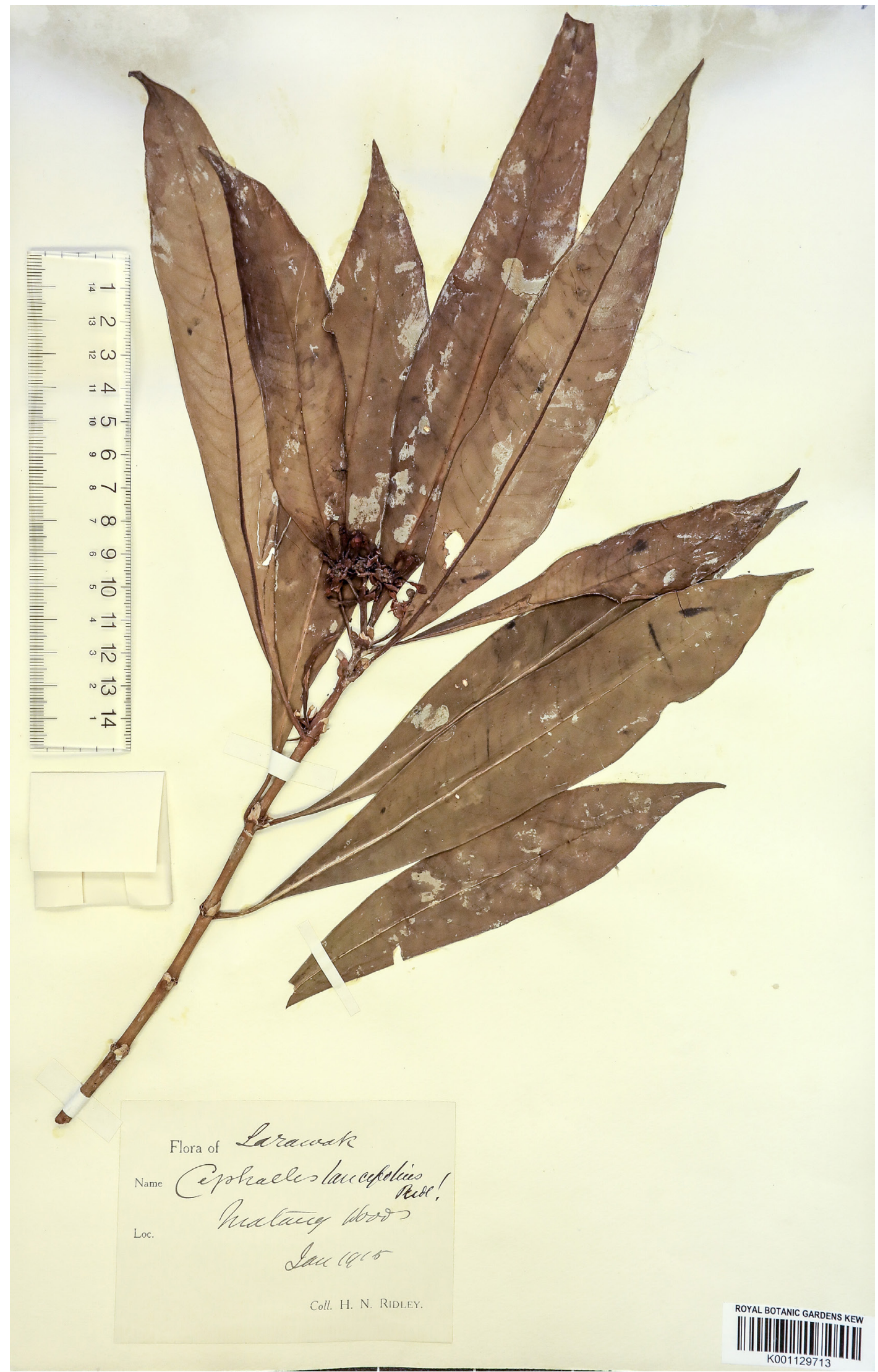

Fig. 17. Holotype of Chassalia lancifolia T.Y.Yu sp. nov. (H.N. Ridley s.n.; K001129713). 


\section{Description}

Tall herb to small treelet, $0.9 \mathrm{~m}$ tall, apparently unbranched, glabrous. Lower internodes terete, upper internodes usually slightly flattened and canaliculate, internodes (1.5)-3-4.5 cm long. Leaf-blades narrowly elliptic to oblanceolate, $10-22 \times 2-4.5 \mathrm{~cm}$, first pair of leaves at apex sometimes bract-like, very narrow, 1-4 cm $\times 2-6 \mathrm{~mm}$; apex acuminate, acumen 1-2 cm long, base attenuate, conspicuously decurrent to petioles, midrib slightly raised above, domatia absent; secondary nerves 10-16 on each side of the midrib, prominent above; tertiary nerves not visible; margin drying with a continuous light-yellow line from apex to base. Petiole short, compressed, $5-20 \times 0.8-2 \mathrm{~mm}$. Stipule triangular to oblong, $5-8 \times$ 3-5 mm, apex usually bilobed, sometimes divided to the base into 2 lobes, each lobe 5-8 $\times 2-3 \mathrm{~mm}$. Inflorescences 1.5-3.5 cm long, subsessile (true peduncle absent or inconspicuous), basal lateral partial peduncles 2, subequal to the main rachis, (appearing as though three terminal inflorescences), short, usually flattened, $5-12 \times 1-1.5 \mathrm{~mm}$; distal partial peduncles absent or short, $0.5-0.8 \times 1-1.5 \mathrm{~mm}$; 5-7 $\times$ 1-2 mm; bracts of rachis 4 , triangular to lanceolate, usually sheathing at base, the 2 longer bracts 10 $12 \times 1-3 \mathrm{~mm}, 2$ shorter bracts $3-5 \times 2 \mathrm{~mm}$; capitular bracts $8-10$, triangular to ovate, $5-6 \times 2-6 \mathrm{~mm}$, outer bracts slightly sheathing at base. Flowers sessile, $8-14$ in each capitulum, glabrous apart from inside corolla tube. Hypanthium 1.5-2 $\times 1-1.5 \mathrm{~mm}$, calyx tube absent, lobes 5, broadly triangular, $0.25 \times 1 \mathrm{~mm}$. Corolla white, glabrous $1-1.8 \mathrm{~cm}$ long in bud, tube slightly broadened at apex, $1 \mathrm{~mm}$ wide at base, apex 2.5-3 mm wide, band of hairs $2 \mathrm{~mm}$ wide, at base of stamens $2.5-3 \mathrm{~mm}$ from mouth of corolla tube, hairs erect, colourless, $0.1-0.2 \mathrm{~mm}$ long; corolla lobes 5 triangular, $3 \times 1.5 \mathrm{~mm}$. Stamens $3 \mathrm{~mm}$ long, slightly concave, base bifurcate, inserted $1 \mathrm{~mm}$ from mouth of corolla, $9 \mathrm{~mm}$ from base of corolla, filaments very short and broad, $0.2 \times 0.2 \mathrm{~mm}$. Style exserted about $2 \mathrm{~mm}$ from mouth of corolla, stigma bilobed, lobes orbiculate, $0.7 \mathrm{~mm}$ diameter. Disc cylindric, $0.8 \times 0.8 \mathrm{~mm}$, apex flat. Fruits sessile, ellipsoid, $8 \times 7 \times 6 \mathrm{~mm}$, fruit colour in vivo not recorded, calyx persistent, not accrescent, $0.5 \times 2 \mathrm{~mm}$, disc persistent, not accrescent, $0.5 \times 1.2 \mathrm{~mm}$. Pyrene plano-convex, 7-8 $\times 5.5-6.5 \times 2-3 \mathrm{~mm}$, dorsal surface convex, with two adjacent parallel longitudinal crests, $0.4 \mathrm{~mm}$ wide, $0.25 \mathrm{~mm}$ apart along their length, forming a longitudinal groove from apex to base between the two crests; ventral surface concave, central part slightly elevated, margin with an endocarpal outgrowth $1 \mathrm{~mm}$ wide, with a groove between the edge of endocarp and endocarpal outgrowth $0.5 \mathrm{~mm}$ wide; raphal opening at base of the endocarpal outgrowth, round, $0.4 \mathrm{~mm}$ wide, $0.2-0.3 \mathrm{~mm}$ from the edge of the pyrene wall, apex with a bony spine, spine triangular, erect, $0.8 \times 0.2 \mathrm{~mm}$. PGS not detected. Seed light brown, hemi-ellipsoid, $6 \times 0.5 \mathrm{~mm}$, longitudinally slightly crested at midline of dorsal surface, endosperm not detected.

\section{Distribution, habitat}

Borneo: Malaysia, Sarawak, Kuching. On undulating, well drained kerangas, alt. 15 m.

\section{Remarks}

No PGS was found on the pyrene of this species like other members of the 'Involucrate group'. However, in this species, the pyrene splits very easily at the base of the dorsal crest close to the raphal opening. The raphal opening of this species is very small.

Chassalia lancifolioides T.Y.Yu sp. nov. urn:Isid:ipni.org:names:77215409-1

Figs $18-19$

\section{Diagnosis}

Differs from Chassalia lancifolia sp. nov. in having more coriaceous leaves, leaf-blades lanceolate but not oblanceolate; in having a longer peduncle $1-6.5 \mathrm{~cm} \times 1.5-2.5 \mathrm{~mm}$, while $C$. lancifolia sp. nov. has a long first internode that resembles a peduncle, but a sessile inflorescence (true peduncle more or less 
absent); in having the fruit not significantly ridged (0.2-0.3 $\mathrm{mm}$ high) compared to C. lancifolia sp. nov.; in the fruit ventral side not as deeply concave as $C$. lancifolia sp. nov.

\section{Etymology}

The epithet reflects the leaf and inflorescence characters that are similar to Chassalia lancifolia sp. nov.

\section{Type}

MALAYSIA - Borneo, Sarawak - Kuching, Lundu District, Sematan area; alt. 20-50 m; $1^{\circ} 47^{\prime}$ N, 10945' E; 26 Apr. 1996; John H. Beaman 12027; holotype: K[K001129714]!; isotypes: UNIMAS, IBEC.

\section{Additional material}

MALAYSIA - Borneo, Sarawak • Kuching, Santubong, Telok Pasir; alt. 100 m; 15 Jun. 1964; Banying \& Sibat S 21547; K!, SAR.

\section{Description}

Shrub to small tree, height not stated, but likely to be more than $40 \mathrm{~cm}$ tall, glabrous. Internodes short, $1-2.5 \mathrm{~cm} \times 2-4 \mathrm{~mm}$, lower internodes terete, upper internodes drying slightly compressed and shorter. Leaf-blades narrowly lanceolate, $13.5-29 \times 1.5-3.5 \mathrm{~cm}$, margin slightly sinuous when dry, a light yellow line visible very near to margin from apex to base; apex acuminate, acumen $1-2 \mathrm{~cm}$, base attenuate, conspicuously decurrent to petioles, midrib slightly raised above, domatia absent; secondary nerves 12-16 on each side of the midrib, prominent above; tertiary nerves not visible. Petiole with a narrow wing on each side, very short, $10-15 \times 1-1.5 \mathrm{~mm}$. Stipule triangular to oblong, $5 \times 4-5 \mathrm{~mm}$, sometimes when old the chaffy part broken and divided into 2. Inflorescences compound cymes, $2-9.5 \mathrm{~cm}$ long. Peduncle longitudinally minutely striate, apex slightly compressed, $1-6.5 \mathrm{~cm} \times 1.5-2.5 \mathrm{~mm}$, rachis and first branches 5-10 $\times 1-1.5 \mathrm{~mm}$, second internode of rachis and second branches absent or very short, 4-5 $\times 1.5-2 \mathrm{~mm}$. Bracts of second internode of rachis and second branches 4, elliptic, $5 \times 1-2 \mathrm{~mm}$, bracts of capitulum 2, ovate, slightly broader than bracts of partial peduncle, $3-5 \times 2-3 \mathrm{~mm}$. Flowers not seen. Hypanthium and calyx tube obovoid, $1.5 \times 1-1.5 \mathrm{~mm}$, calyx lobes $1.25 \times 0.7-1 \mathrm{~mm}$. Fruits shiny green, prolate, $7 \times 5-6 \mathrm{~mm}$, pedicel short, around $1 \mathrm{~mm}$ long. Pyrenes plano-convex, compressed, $7 \times 6 \mathrm{~mm}$, dorsal surface convex, with two adjacent parallel longitudinal crests, each $0.25 \mathrm{~mm}$ wide, $0.15 \mathrm{~mm}$ apart along their length, $0.2-0.3 \mathrm{~mm}$ high, forming a longitudinal groove from apex to base between the two crests; ventral surface slightly concave, centrally slightly elevated, margin with an endocarpal outgrowth $0.5-0.8 \mathrm{~mm}$ wide, with a groove between the edge of endocarp and endocarpal outgrowth $0.25 \mathrm{~mm}$ wide. Raphal opening at base of the endocarpal outgrowth, large, round to trullate, $0.5 \mathrm{~mm}$ wide or $1.5 \mathrm{~mm} \times 0.5 \mathrm{~mm}$ if trullate, $0.3-0.4 \mathrm{~mm}$ from the edge of the pyrene wall, apex with a bony spine, spine triangular, erect, $1 \times 0.3 \mathrm{~mm}$. PGS not detected. Seed light brown, hemi-ellipsoid, slightly crested at central part of dorsal side, $6 \times 0.5 \mathrm{~mm}$, endosperm not detected.

\section{Distribution, habitat}

Borneo: Malaysia, Kuching, around Lundu. Kerangas forest, alt. 20-50 m.

\section{Remarks}

The pyrenes of both this species and Chassalia lancifolia sp. nov. can be very easily separated into two parts between the raphal opening and the base of dorsal groove between the two crests. 


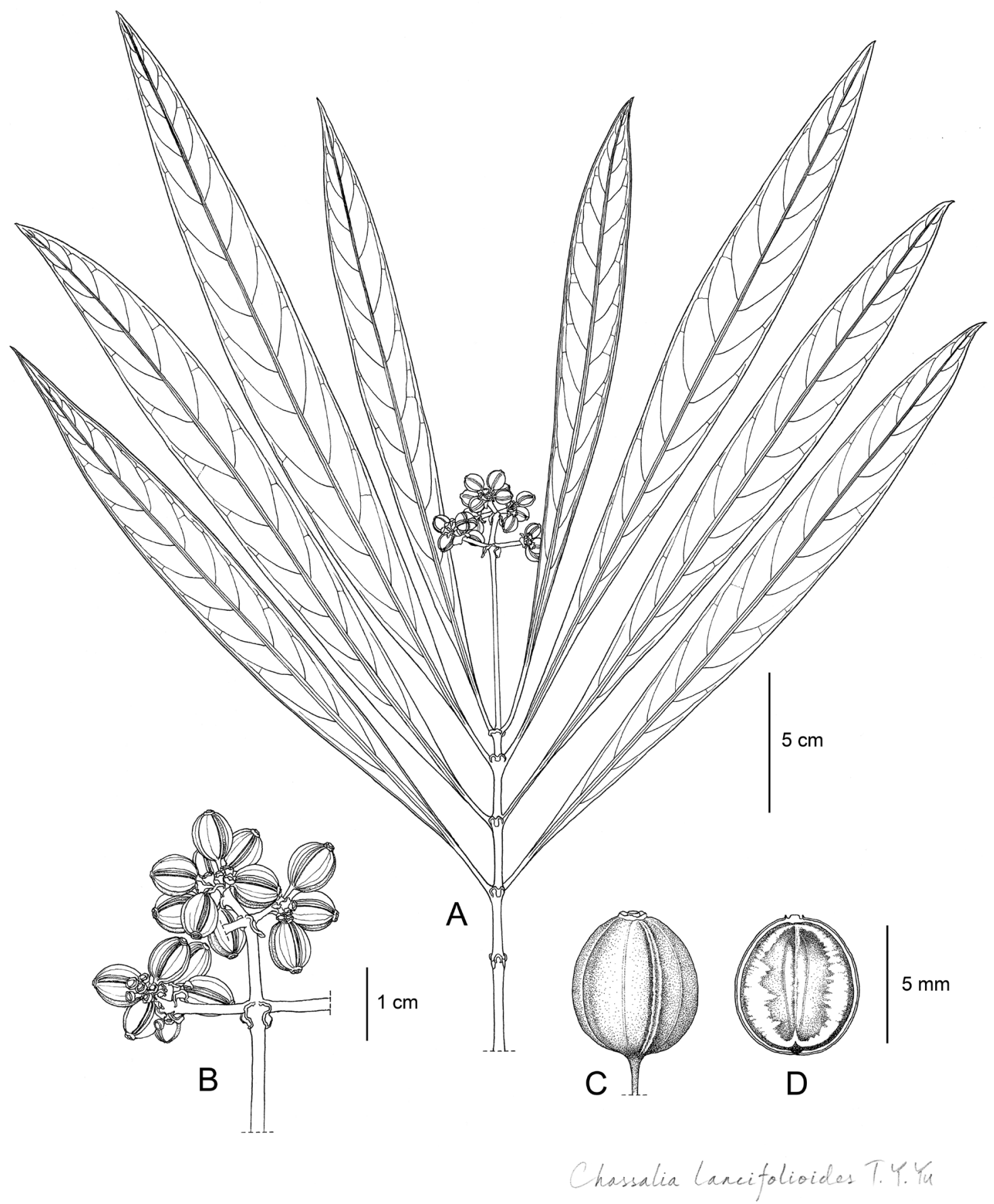

Fig. 18. Chassalia lancifolioides T.Y.Yu sp. nov. A. Flowering shoot. B. Infructescence. C. Dry fruit. D. Pyrene ventral surface. From John H. Beaman 12027. Drawn by T.Y. Yu. 


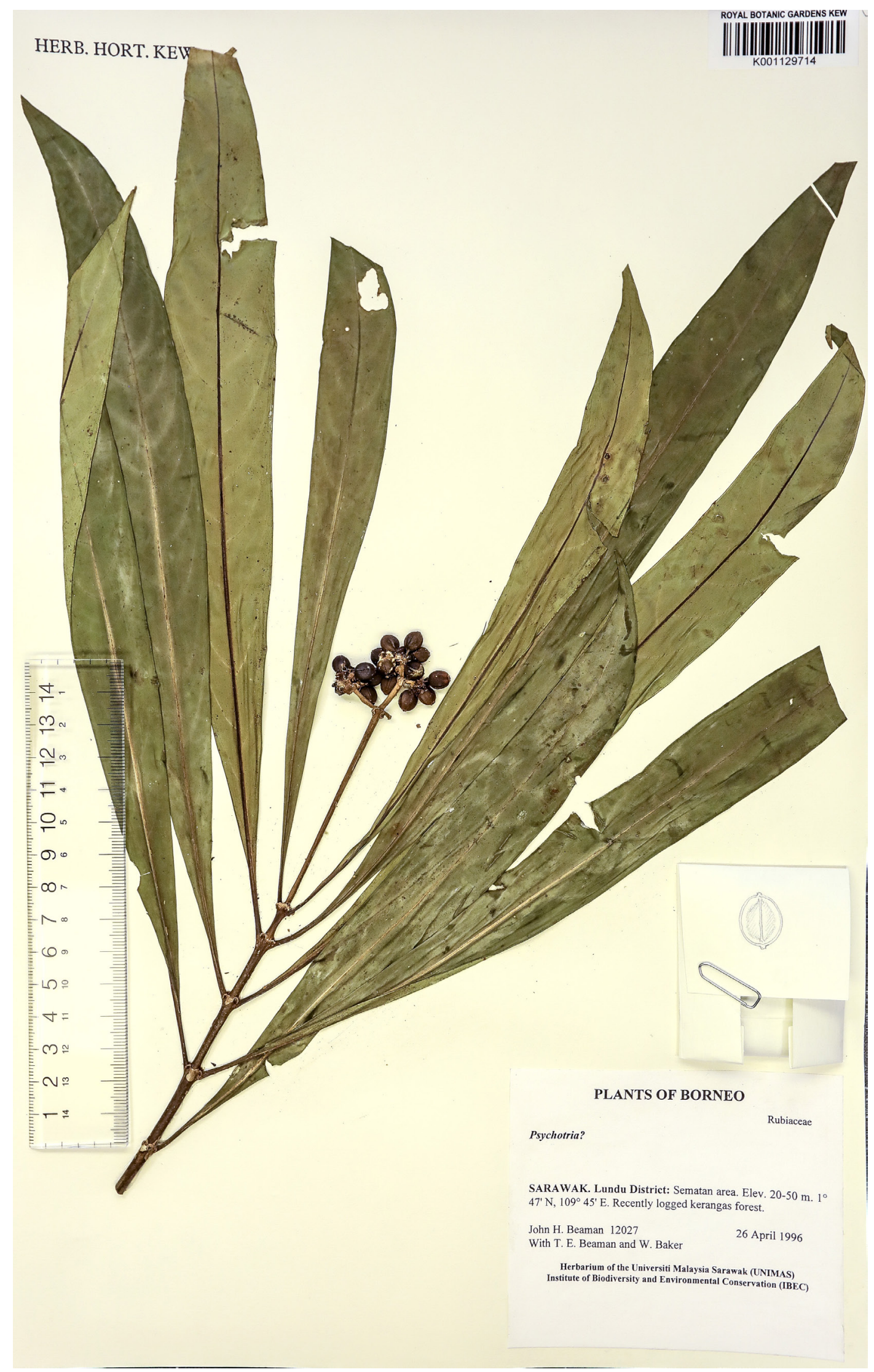

Fig. 19. Holotype of Chassalia lancifolioides T.Y.Yu sp. nov. (John H. Beaman 12027). 
Chassalia longipes T.Y.Yu sp. nov.

urn:lsid:ipni.org:names:77215410-1

Figs 20-21

\section{Diagnosis}

Differs from all other species of Chassalia in having a peduncle up to $10 \mathrm{~cm}$ long and inflorescence usually longer than the longest leaf; in the inflorescence usually having 3 branches with each branch bearing a single capitulum.

\section{Etymology}

The chosen epithet reflects the relatively long peduncle, rachis and branches of inflorescence.

\section{Type}

MALAYSIA - Borneo, Sabah - Ranau District, Mount Kinabalu, Summit Trail at Pondok Ubah; $6^{\circ} 03^{\prime}$ N, 116³3' E; alt. 2100 m; 9 May 1995; Teofila E. Beaman 275; holotype: K[K001129716]!.

\section{Additional material}

MALAYSIA - Borneo, Sabah • Penampang, Sunsuron, Path to kg. Longkogungan, Km 51; SAN 121756 ; K! • Ranau, Kinabalu National Park; 559'65" N, 116³1'82" E; alt. 1971 m; SAN 148497; K! • Ranau district, East Mesilau River near Mesilau Cave; $6^{\circ} 03^{\prime} \mathrm{N}, 116^{\circ} 36^{\prime} \mathrm{W}$; alt. 1700-1950 m; John H. Beaman $10681 ; \mathrm{K} !$.

\section{Description}

Shrub, $1 \mathrm{~m}$ tall, glabrous. Stems terete. Internodes of the flowering branch $(1.5-) 2-4.5(-6.5) \mathrm{cm} \times$ $2-3 \mathrm{~mm}$, flowering internode usually reduced, $0.5-1.7 \mathrm{~cm}$ long. Leaf-blades narrowly elliptic to oblanceolate, sometimes narrowly rhombic, $(6-) 8-12.5(-13.5) \times 2.2-3.8 \mathrm{~cm}$, margin entire, apex acute to acuminate, acumen $5-10 \mathrm{~mm}$ long; base cuneate; midrib slightly raised above, domatia absent; secondary nerves 6-9 on each side of the midrib, prominent above; tertiary nerves not visible. Petiole flattened, canaliculate, (3-)8-15 × $1 \mathrm{~mm}$. Stipule not sheathing, oblong-elliptic, 3-7 $\times$ 4-6 mm. Inflorescences compound cymose, $11.5-16 \mathrm{~cm}$ long; peduncle terete, $4.5-8.5(-10) \mathrm{cm}$ long; partial peduncle $2-7 \mathrm{~cm}$ long; central partial peduncle sometimes with rachis and tertiary branches, rachis $6 \mathrm{~cm}$ long; tertiary branches of rachis cymose, 1-1.3 cm long; bract of tertiary branches $8-10 \times 4 \mathrm{~mm}$. Bracts of peduncle and partial peduncle 2, opposite, sheathing at base, sheath 1-3 mm, apex triangular to ensiform, $6-10 \times$ $0.5-2.5 \mathrm{~mm}$, slightly denticulate at apex with 3-6 teeth on each side or entire, teeth $0.2 \mathrm{~mm}$ long. Bracts of each capitulum 6-10, outer bracts ovate to elliptic, 5-6 $62-3 \mathrm{~mm}$, inner bracts smaller, elliptic to lanceolate, 5-6 $\times 0.8-1 \mathrm{~mm}$. Flowers capitate, sessile in terminal clusters, pedicel absent. Hypanthium obovoid, glabrous, 2-3 mm long; calyx 5-lobed with each lobe broadly triangular, $0.5 \times 1 \mathrm{~mm}$. Corolla cream white, tube 7-8 mm long, broadening from midway to top, lower part $1.5 \mathrm{~mm}$ wide, apex $5 \mathrm{~mm}$ wide; lobes triangular, 3.5-4 $\times 3-4 \mathrm{~mm}$, apex acute or apiculate. Fruits shimmering blue, ellipsoid, (1-)7-9 on each capitulum, 7-8 $\times$ 4-6 mm. Disc $0.5 \times 1 \mathrm{~mm}$. Pyrenes plano-convex, dorsal surface convex, with two adjacent parallel longitudinal crests, each $0.5 \times 0.2-0.3 \mathrm{~mm}$, curved, slightly grooved longitudinally from apex to base between the two crests; ventral surface concave, centrally slightly elevated, margin with an endocarpal outgrowth $0.2 \mathrm{~mm}$ wide. Raphal opening at base of the endocarpal outgrowth, round, $0.1 \mathrm{~mm}$ long, $0.5 \mathrm{~mm}$ from the edge of the pyrene wall, apex with a bony spine, spine triangular, erect, $0.8 \times 0.1 \mathrm{~mm}$. PGS not detected. Seed brown, hemi-ellipsoid, slightly crested at central part of dorsal side, $4 \times 1 \mathrm{~mm}$, endosperm not detected. 


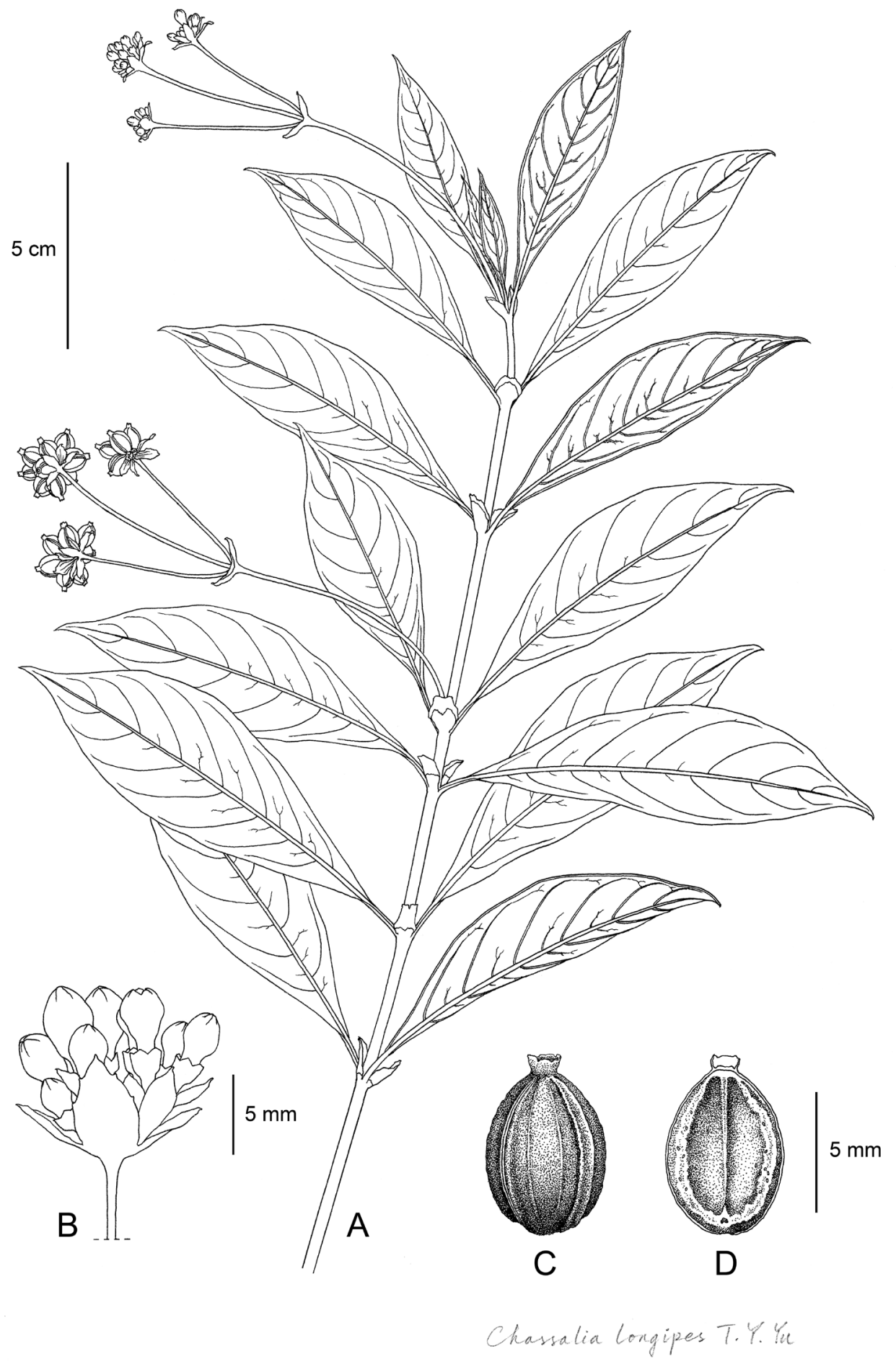

Fig. 20. Chassalia longipes T.Y.Yu sp. nov. A. Flowering shoot. B. Capitulum. C. Dry fruit. D. Pyrene ventral surface. A, C-D from Teofila E. Beaman 275; B from John H. Beaman 10681. Drawn by T.Y. Yu. 


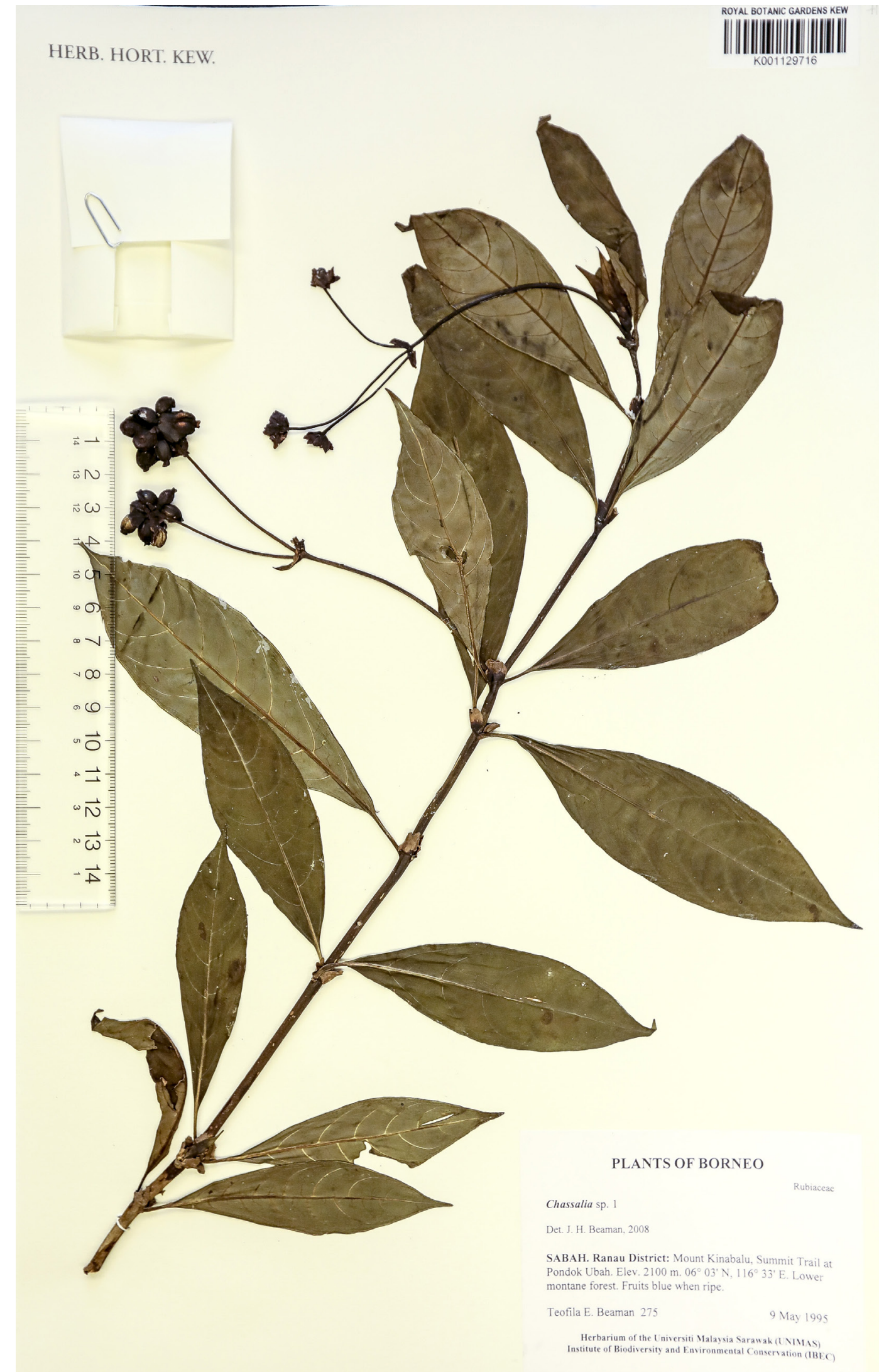

Fig. 21. Holotype of Chassalia longipes T.Y.Yu sp. nov. (Teofila E. Beaman 275). 


\section{Distribution, habitat}

Borneo: Malaysia, Sabah, Ranau; Mount Kinabalu; Penampang. Lower montane forest, alt. 1970 $2100 \mathrm{~m}$.

Chassalia macrocarpa T.Y.Yu sp. nov.

urn:lsid:ipni.org:names:77215411-1

Figs 22-23

\section{Diagnosis}

Differs from all other Bornean species of Chassalia in having relatively large fruits $(10-12 \times 10 \times$ $5 \mathrm{~mm}$ ); differs from other species of Chassalia from Mt Matang in having larger rachis and capitulum bracts, rachis bracts usually round or acuminate with long acumen which covers the flower buds, and in fruits becoming pale yellowish brown when dry.

\section{Etymology}

The epithet was chosen because, within Borneo, this species of Chassalia has large fruits $(1.2 \times 1 \times$ $0.5 \mathrm{~cm})$.

\section{Type}

MALAYSIA - Borneo, Sarawak $・ 1^{\text {st }}$ Division, Kuching, Matang, Path to Bukit Tanduk; alt. 750 m; 23 Apr. 1987; Bernard Lee Meng Hock S 54027; holotype: K[K001129715]!; isotype: SAN.

\section{Additional material}

MALAYSIA - Borneo, Sarawak $・ 1^{\text {st }}$ Division, Kuching, Matang, by trail; alt. 450 m; 27 Oct. 1929; M. \& J. Clemens 22373; K!, SAR • 28 Oct. 1929; M. \& J. Clemens 22373; K!, SAR • alt. 500 m; 31 Jul. 1963; Paul Chai S 18534; A, K!, L, SAN, SAR • Feb. 1915; H.N. Ridley s.n.; K!.

\section{Description}

Shrub, 1-1.5 m tall, glabrous. Internodes (1-)1.5-4.5 $\mathrm{cm} \times 3-4 \mathrm{~mm}$, lower internodes terete, upper internode usually drying flattened, canaliculate, broadening at apex. Leaf-blades narrowly elliptic to narrowly lanceolate, $15-24 \times 2-5.5 \mathrm{~cm}$, margin entire, apex acute to acuminate, base cuneate; midrib slightly raised above, domatia absent; secondary nerves $12-16$ on each side of the midrib, prominent above; tertiary nerves not visible. Petiole very short, canaliculate, usually slightly winged, 10-25 $\times$ 1-2 mm. Stipule not sheathing, broadly flabellate, $1-2 \times 1-1.5 \mathrm{~cm}$, apex usually broken. Inflorescence a compound cyme, (1-)1.8-5 cm long; peduncle (0.5-)1.5-3.5 cm long; Bracts of second internode of rachis and second branches 2 , round to elliptic, $1.2 \times 1 \mathrm{~cm}$, usually slightly sheathing at base, apex obtuse, sometimes acuminate with acumen $5 \mathrm{~mm}$ long, second branches usually very short to absent, bracts of capitulum elliptic, 10-12 $\times 5-10 \mathrm{~mm}$. Open flowers not seen. Fruits purplish blue when young, blue when ripe, light yellowish brown when dry, obovoid, 10-12 $10 \times 5 \mathrm{~mm}$. Pyrenes plano-convex, dorsal surface convex, with two adjacent parallel longitudinal crests, each $0.3 \mathrm{~mm}$ wide, curved, $0.3 \mathrm{~mm}$ apart along their length, forming a longitudinal groove from apex to base between the two crests; ventral surface concave, centre slightly elevated, margin with an endocarpal outgrowth $0.5-0.8 \mathrm{~mm}$ wide and a groove between the edge of endocarp and endocarpal outgrowth $0.3-0.5 \mathrm{~mm}$ wide. Raphal opening at base of the endocarpal outgrowth, round, $0.2-0.3 \mathrm{~mm}$ diameter, $0.2-0.3 \mathrm{~mm}$ from the edge of the pyrene wall, apex with a bony spine, flabellate, erect, $1.5 \times 0.3 \times 0.6-0.7 \mathrm{~mm}$. PGS not detected. Seed not seen.

\section{Distribution, habitat}

Borneo: Malaysia, Sarawak, $1^{\text {st }}$ Division, Kuching, Matang. Mixed dipterocarp forest, alt. 450-750 m. 


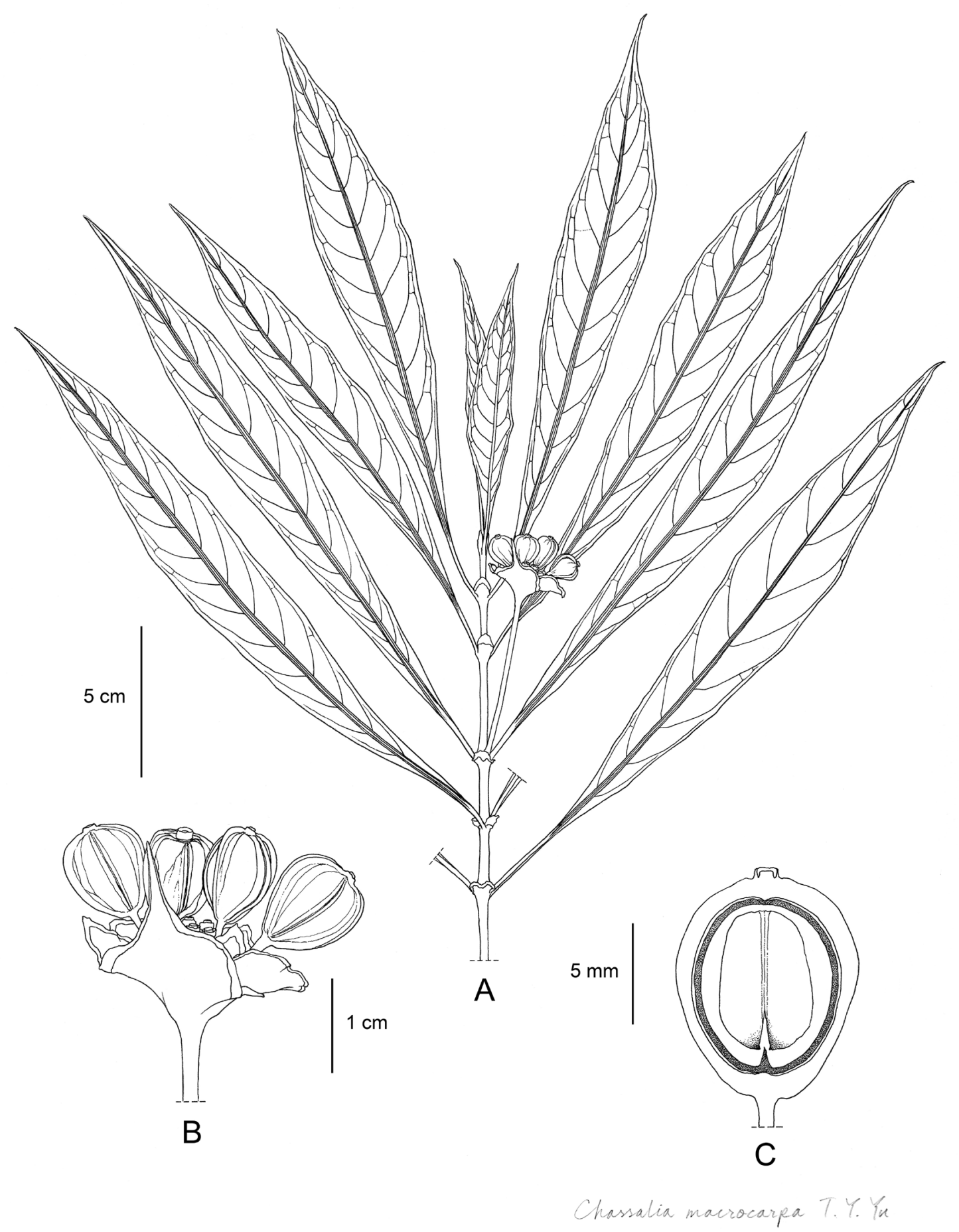

Fig. 22. Chassalia macrocarpa T.Y.Yu sp. nov. A. Flowering shoot. B. Infructescence showing dry fruit. C. Pyrene ventral surface. From Bernard Lee Meng Hock S 54027. Drawn by T.Y. Yu. 


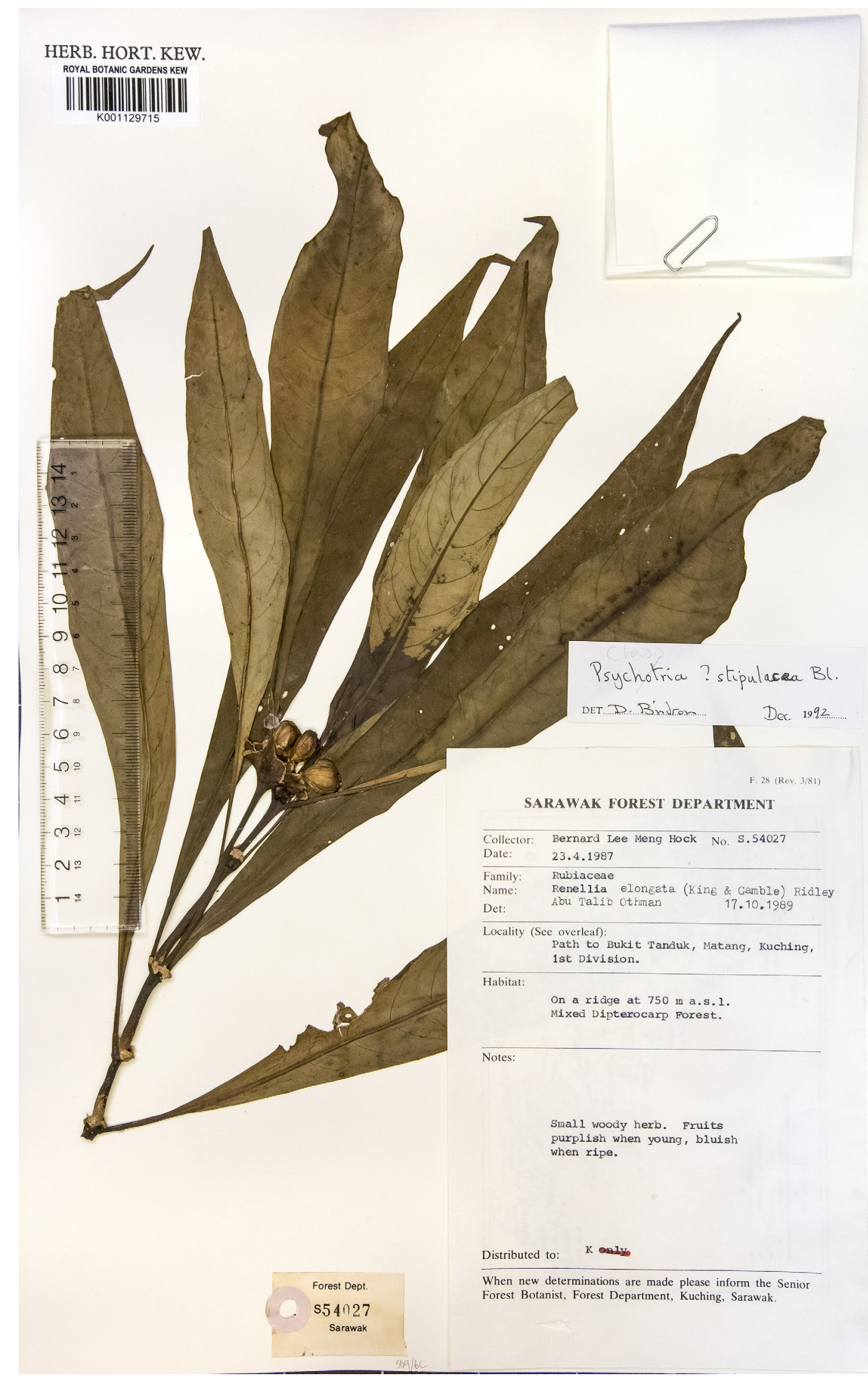

Fig. 23. Holotype of Chassalia macrocarpa T.Y.Yu sp. nov. (Bernard Lee Meng Hock S 54027). 
Chassalia muluensis T.Y.Yu sp. nov.

urn:lsid:ipni.org:names:77215412-1

Figs 24-25

\section{Diagnosis}

Differs from other Bornean species of Chassalia by having secondary nerves densely distributed, 16-18 on each side of the midrib; stipule broadly flabellate, 5-8 × 5-12 mm; inflorescence 9.5-14 cm long, longer than the average leaf, but usually shorter than the longest leaf; only found in Gunung Mulu National Park.

\section{Etymology}

The epithet alludes to Gunung Mulu National Park to which this species is endemic.

\section{Type}

MALAYSIA - Borneo, Sarawak • Gunung Mulu National Park, west ridge just below Camp 4; $4^{\circ} 03^{\prime} \mathrm{N}$, 114 53' E; alt. 1600 m; submontane ridge forest; 29 Apr. 1978; fl.; G. Argent, B. Coppins 1134; holotype: K[K001129717]!; isotype: KEP[KEP271647].

\section{Additional material}

MALAYSIA - Borneo, Sarawak • Gunong Mulu National Park, ridge west of Camp 4; $4^{\circ} 05^{\prime} \mathrm{N}$,

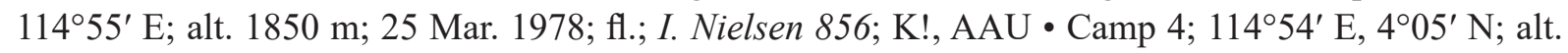
1800 m; slope in moss forest in upper montane forest; 22 Mar. 1978; fl.; Carlo Hansen 544; K!.

\section{Description}

Subshrub, shrub or sub-woody epiphyte, $0.75-2 \mathrm{~m}$ high, glabrous. Stem terete, 3-4 mm wide. Internodes of the flowering branch 1-3 cm long, lower internode terete, upper internode usually drying flattened, canaliculate, broadening at apex, base 2-4 mm wide, apex 3-5 mm wide. Leaves opposite, decussate. Leaf-blades elliptic, $6.5-14.5 \times 3-5.8 \mathrm{~cm}$; apex acute to acuminate, acumen 5-15 mm long; base attenuate; midrib slightly raised above, domatia absent; secondary nerves 16-18 on each side of the midrib, prominent above; tertiary nerves not visible. Petiole flattened, canaliculate, $3-4 \mathrm{~cm} \times 1-2 \mathrm{~mm}$. Stipule not sheathing, flabellate, 5-8 $\times 5-12 \mathrm{~mm}$, apex breaking very easily, base drying deep brown, margin light brown. Inflorescence a compound cyme, $9.5-14 \mathrm{~cm}$ long, peduncle $6.5-8 \mathrm{~cm}$ long, bracts of first internode of rachis narrowly elliptic, 2-4, 9-12 $\times 3-6 \mathrm{~mm}$, first internode of rachis and first branches 1.5-3 cm long, bracts of second internode of rachis and second branches 4 , ovate to elliptic, $10 \times 5 \mathrm{~mm}$, bracts of capitulum 5-6, narrowly elliptic, 5-10 $\times 2-5 \mathrm{~mm}$, second internode of rachis and second branches 5-10 mm long or absent. Flowers 12-18 in each capitulum, hypanthium $2 \times 2-3 \mathrm{~mm}$, calyx tube $1-1.2 \times 1.5 \mathrm{~mm}$, lobes of calyx tube $0.3 \times 0.3-0.5 \mathrm{~mm}$, corolla tube $8-12 \times 3-4 \mathrm{~mm}$, inside corolla tube a band of hairs $0.5 \mathrm{~mm}$ wide at base of stamens, $3 \mathrm{~mm}$ from mouth of corolla tube, hairs erect, colourless, $0.1-0.2 \mathrm{~mm}$ long; corolla lobes $2 \times 2-3 \mathrm{~mm}$, stamens $2.5 \times 0.5 \mathrm{~mm}$, filament $0.5 \times$ $0.1 \mathrm{~mm}$, style ca 1.5 times as long as corolla, $1.8 \mathrm{~cm}$ long. Disc cylindric, $0.7 \times 0.9 \mathrm{~mm}$. Fruits ellipsoid, dark purple when ripe, 7.5-8 $\times 4-5.5 \times 4-5.5 \mathrm{~mm}$, pyrenes plano-convex, dorsal surface convex, with two adjacent parallel longitudinal crests, each $0.2 \mathrm{~mm}$ wide, curved, $0.2 \mathrm{~mm}$ apart along their length, forming a longitudinal groove from apex to base between the two crests; ventral surface concave, centre slightly elevated, margin with an endocarpal outgrowth $0.4-0.5 \mathrm{~mm}$ wide and a groove between the edge of endocarp and endocarpal outgrowth $0.2-0.3 \mathrm{~mm}$ wide. Raphal opening at base of the endocarpal outgrowth, round, $0.3 \mathrm{~mm}$ diameter, $0.2 \mathrm{~mm}$ from the edge of the pyrene wall, apex with a bony spine, erect, $1 \times 0.2 \mathrm{~mm}$. PGS not detected. Seeds brown, hemi-ellipsoid, slightly crested at central part of dorsal side, $3.2 \times 0.6 \mathrm{~mm}$. 


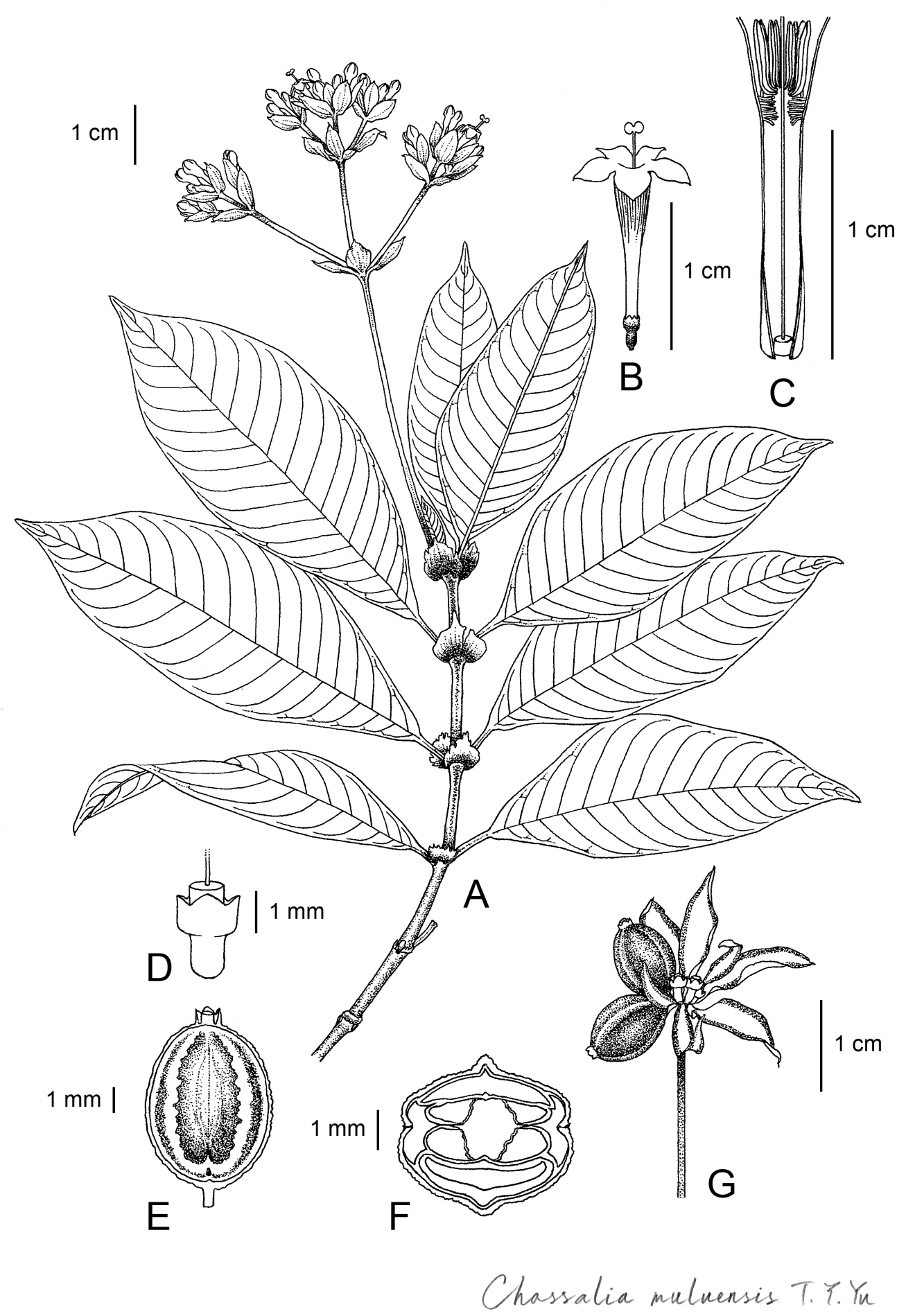

Fig. 24. Chassalia muluensis T.Y.Yu sp. nov. A. Flowering shoot. B. Flower. C. Longitudinal view of corolla tube showing stamens, band of hairs, style and disc. D. Hypanthium, calyx and disc of a flower. E. Pyrene ventral surface. F. Dry fruit transection. G. Part of infructescence, showing dry fruit. From G. Argent, B. Coppins 1134. Drawn by T.Y. Yu. 


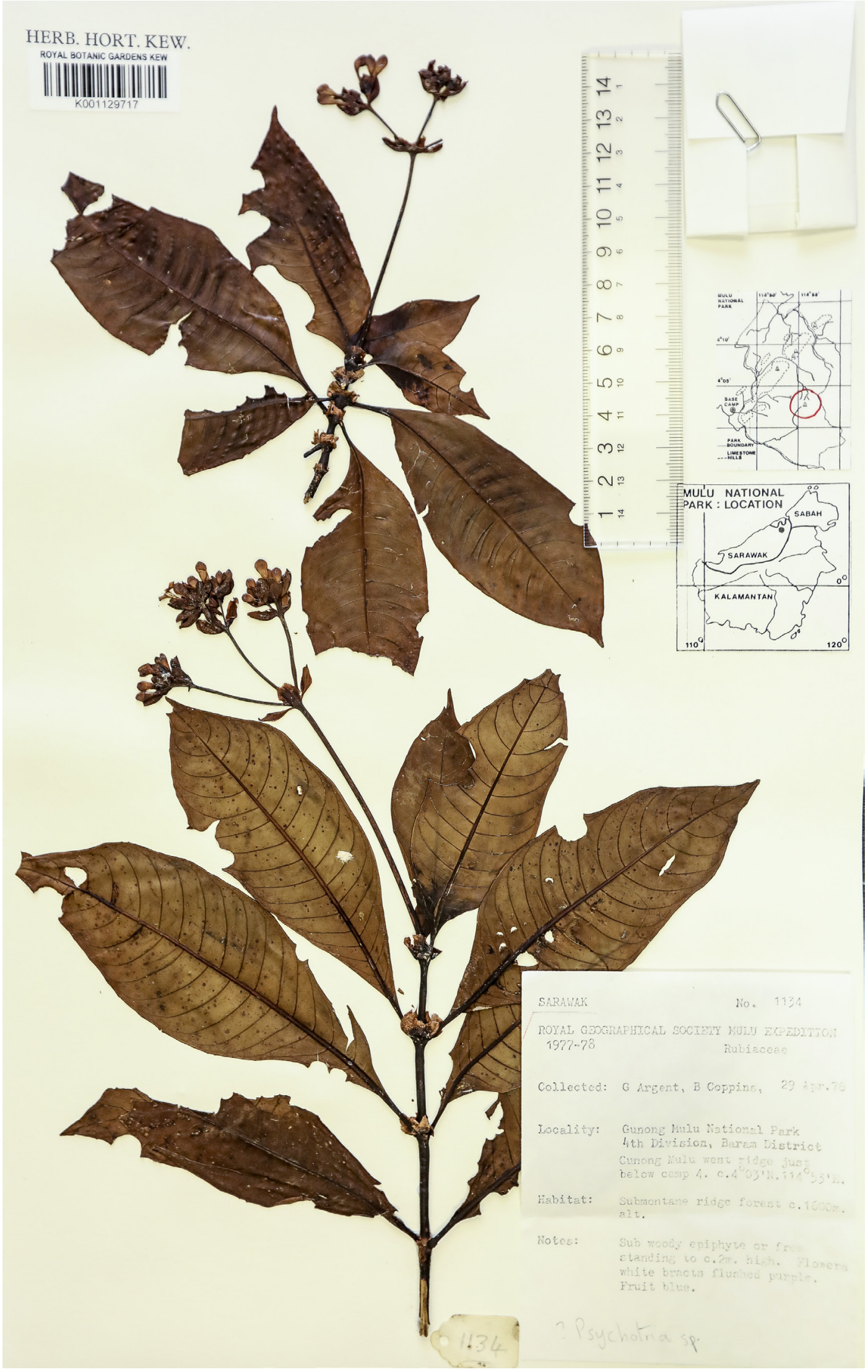

Fig. 25. Holotype of Chassalia muluensis T.Y.Yu sp. nov. (G. Argent, B. Coppins 1134). 


\section{Distribution, habitat}

Borneo: Malaysia, Sarawak, Gunung Mulu National Park, around Camp 4. Slope in moss forest in upper sub-montane to montane forest, alt. 1600-1850 m.

Chassalia muscicola T.Y.Yu sp. nov. urn:Isid:ipni.org:names:77215413-1

Figs 26-27

\section{Diagnosis}

This is the smallest of all Bornean species of Chassalia, differing from all other species in being just $25-30 \mathrm{~cm}$ tall (other species are at least $40 \mathrm{~cm}$ tall, and usually a minimum of $1 \mathrm{~m}$ tall), in the obovate leaves just 5.5-7.5 cm long (in other species they exceed $10 \mathrm{~cm}$ long and may attain $48 \mathrm{~cm}$ long), in the apex of leaves obtuse (acute or acuminate in most other species), in having large white fruits $8 \times 7 \times$ $7 \mathrm{~mm}$ (all other species have blue or purple or black fruits), in having a large bony spine $2 \times 1 \times 0.5 \mathrm{~mm}$ on the ventral surface of the pyrene.

\section{Etymology}

The epithet alludes to summit moss forest where it has been collected.

\section{Type}

MALAYSIA - Borneo, Sarawak $1^{\text {st }}$ Div., Simunjan, Serian/S'ggang Rd., Gunong Gaharu $70^{\text {th }}$ Mile; alt. 800 m; 8 Oct. 1974; Ilias \& Azahari S 35671; holotype: K[K001129718]!; isotypes: L, KEP, SAR.

\section{Additional material}

MALAYSIA - Borneo, Sarawak • 2 ${ }^{\text {nd }}$ Div., Gunong Aping; alt. 900 m; 13 Jul. 1961; S. Collenette 742; $\mathrm{K}$ !, SAN.

\section{Description}

Herb, 25-30 cm tall, glabrous, almost half of the plant growing among mosses. Stem 1-2 mm wide, usually producing adventitious roots $1-8 \mathrm{~cm}$ below lowest internode, internodes $1.8-3.5 \mathrm{~cm}$ long, lower internodes terete, upper internodes drying flat, slightly canaliculate. Leaf-blades narrowly obovate to oblanceolate, coriaceous, adaxially dark green, abaxially light yellowish-green, (2.5-)4-6.5 × 1.3$1.8 \mathrm{~cm}$; apex obtuse, base attenuate; midrib slightly raised both adaxially and abaxially, secondary nerves $7-12$ on each side, tertiary nerves not visible; petiole short, 5-10 $\mathrm{mm}$ long. Stipule flabellate, 5-7 $\times 4-5 \mathrm{~mm}$. Inflorescences short, $4.5 \mathrm{~cm}$ long, peduncle $3.5 \mathrm{~cm} \times 0.8 \mathrm{~mm}$, broadening near apex to $2 \mathrm{~mm}$ wide, bracts of first internode of rachis and first branches 4 , broadly elliptic, $4.5 \times 2-3.5 \mathrm{~mm}$; first internode of rachis and first branches very short to absent, usually less than $1 \mathrm{~mm}$; bracts of capitulum 4-6 or more, $4-4.5 \times 1-4.5 \mathrm{~mm}$, with crystal bodies on each rachis bract and capitulum bract. Flowers 6-12 in each capitulum, open flowers not seen; hypanthium $1.5-2 \mathrm{~mm}$ long, calyx tube $0.7 \mathrm{~mm}$ long, apex slightly curved. Corolla white, glabrous, $1-1.8 \mathrm{~cm}$ long in bud, tube slightly broadened at apex, $5 \mathrm{~mm}$ long before opening, $1 \mathrm{~mm}$ wide at base, apex 2.5-3 mm wide, band of hairs $1 \mathrm{~mm}$ wide, at base of stamens $1-2 \mathrm{~mm}$ from mouth of corolla tube, hairs erect, colourless, $0.1-0.2 \mathrm{~mm}$ long; open flower not seen. Stamens $1 \times 0.5 \mathrm{~mm}$, slightly concave, base bifurcate, inserted ca $1.5 \mathrm{~mm}$ from mouth of corolla, filaments very short to absent. Stigma bilobed, lobes orbiculate, $0.6 \mathrm{~mm}$ diameter. Disc cylindric, $0.4 \mathrm{~mm}$ long, $0.7 \mathrm{~mm}$ wide, apex flat. Fruits sessile, ellipsoid, $7-8 \times 7 \times 7 \mathrm{~mm}$, pure white; calyx persistent, not accrescent, $1 \times 2 \mathrm{~mm}$, disc persistent, not accrescent, $0.5 \times 1 \mathrm{~mm}$. Pyrenes plano-convex, 7-8 $\times$ 6-7 $\times 4 \mathrm{~mm}$, dorsal surface convex, with two adjacent parallel longitudinal crests, $1 \mathrm{~mm}$ wide, $1 \mathrm{~mm}$ high, $0.5 \mathrm{~mm}$ apart along their length, forming a longitudinal groove from apex to base between the 


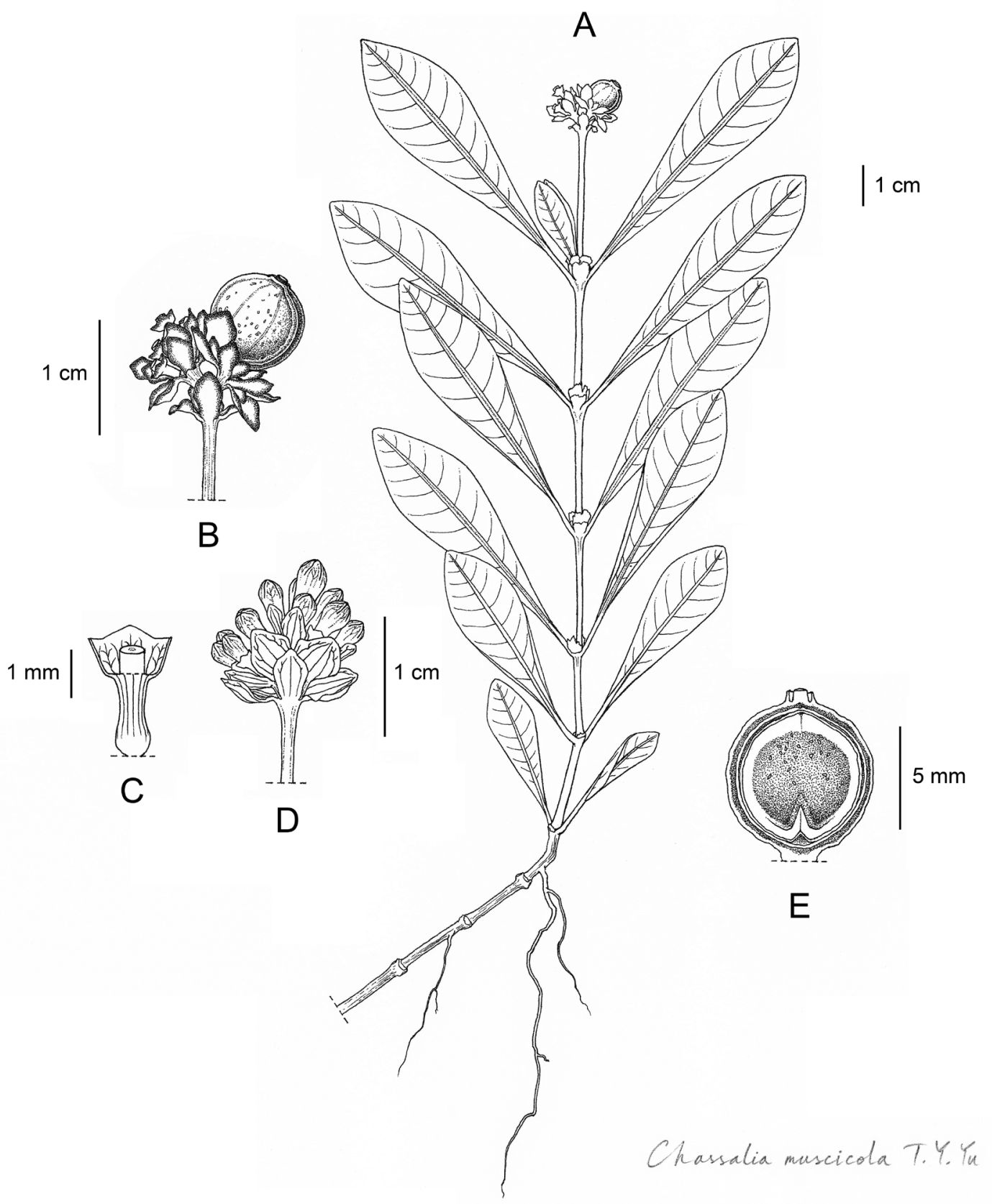

Fig. 26. Chassalia muscicola T.Y.Yu sp. nov. A. Habit. B. Infructescence. C. Hypanthium, calyx and disc of a flower. D. Inflorescence. E. Pyrene ventral surface. A-B, E from Ilias \& Azahari S 35671; C-D from $S$. Collenette 742. Drawn by T.Y. Yu. 


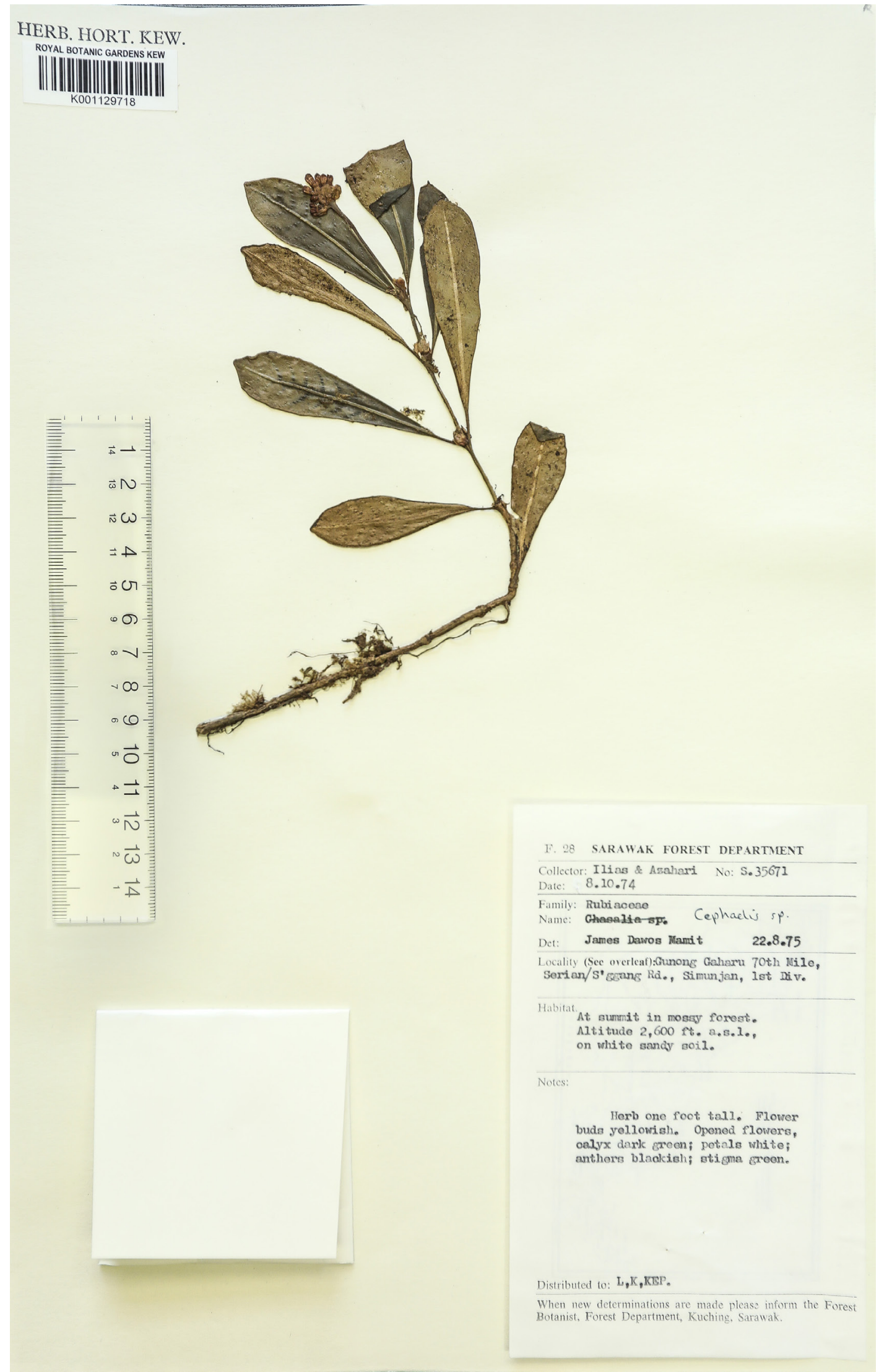

Fig. 27. Holotype of Chassalia muscicola T.Y.Yu sp. nov. (Ilias \& Azahari S 35671). 
two crests; ventral surface concave, central part slightly elevated, margin with an endocarpal outgrowth $0.2 \mathrm{~mm}$ wide, with a groove between the edge of endocarp and endocarpal outgrowth $0.2 \mathrm{~mm}$ wide. Raphal opening at base of the endocarpal outgrowth, round, $0.5 \mathrm{~mm}$ wide, $0.2-0.3 \mathrm{~mm}$ from the edge of the pyrene wall, apex with a bony spine, flabellate, $2 \times 1 \times 0.5 \mathrm{~mm}$. PGS not detected. Seed light brown, hemi-ellipsoid, $6 \times 0.5 \mathrm{~mm}$, longitudinally slightly crested at midline of dorsal surface, endosperm not detected.

\section{Distribution, habitat}

Borneo: Malaysia, Sarawak, Gunung Gaharu ( $1^{\text {st }}$ Division) and Gunung Aping ( $2^{\text {nd }}$ Division $)$, summit of mountain, moss forest, alt. 800-900 m.

Chassalia northiana T.Y.Yu sp. nov.

urn:Isid:ipni.org:names:77215414-1

Figs $28-29$

\section{Diagnosis}

Differs from Chassalia blumeana Govaerts to which it is most similar, by having inflorescence branches and rachis $\geq 5 \mathrm{~mm}$, usually $1-5 \mathrm{~cm}$ long, bracts of inflorescence branches and rachis usually consist of 2 leaf-like bracts and 2 stipule-like bracts, leaf-like bracts sometimes develop to 3-7 cm long.

\section{Etymology}

Named for Marianne North (1830-1890), who included this plant in painting 624 entitled Curious Plants from the Forest of Matang, Sarawak, Borneo (https://images.kew.org/botanical-art/mariannenorth/624-curious-plants-forest-matang-sarawak-5122480.html) which is the first image record of this species, made in the 1860s. It is possibly the earliest record of the genus from Borneo.

\section{Type}

MALAYSIA - Borneo, Sarawak - First Division, Kuching, Matang, proposed Matang National Park, Sungai Sendok; 8 May 1987; Bernard Lee Meng Hock S 53828; holotype: K[K001129725]!; isotype: SAR.

\section{Additional material}

MALAYSIA - Borneo, Sabah • Ranau, Mininsalu; 22 Sep. 1988; Amin \& Prancis SAN 123432; K, SAN. - Borneo, Sarawak - Sg. Rayu, Matang Forest Reserve; 27 Mar. 1988; Munting \& Jugah, $S$ 55620; K!, SAR $\bullet 5^{\text {th }}$ Division, along Sg. Maisa in Maligan Range, Lawas; alt. $3400 \mathrm{ft}$; 13 Mar. 1973; Ilias Paie S 32900; K!, SAR • Sri Aman Division, Temawai Berau, Sungai Selepong; 6 Apr. 1990; Rena, Runi, Rantai et al. S 58511; K!, SAR.

\section{Description}

Herb, shrub to small tree, 1-2 m tall, glabrous. Stem terete, young parts of stems slightly flattened and canaliculate when dry, internode 3-8 $\mathrm{cm} \times 2-4 \mathrm{~mm}$. Leaf-blades obovate to elliptic, usually broadest at $1 / 3$ to $1 / 2$ length from apex, 12-27 $\times 4-9 \mathrm{~cm}$, apex acuminate with acumen $1-1.5(-3) \mathrm{cm}$ long, base truncate, midrib slightly raised above from both adaxial and abaxial, secondary nerves 8-14 on each side of the midrib, petioles $1-6 \mathrm{~cm}$ long. Stipule flabellate, margin usually broken, sometimes slightly bilobed or incised, $8-14 \times 5-14 \mathrm{~mm}$, with standard colleters inside. Inflorescence compound cyme, terminal, usually with rachis and 2 branches, 6-14 cm long in total. Peduncle 4-7.5 cm long, branches and first internode of rachis $1-4 \mathrm{~cm}$ long, branches usually $0.5-1 \mathrm{~cm}$ shorter than rachis, bracts of branches and first internode of rachis usually 4 , separate or sheathed at base, 2 leaf-like bracts $1-1.8 \mathrm{~cm} \times 1.5-2 \mathrm{~mm}$, 


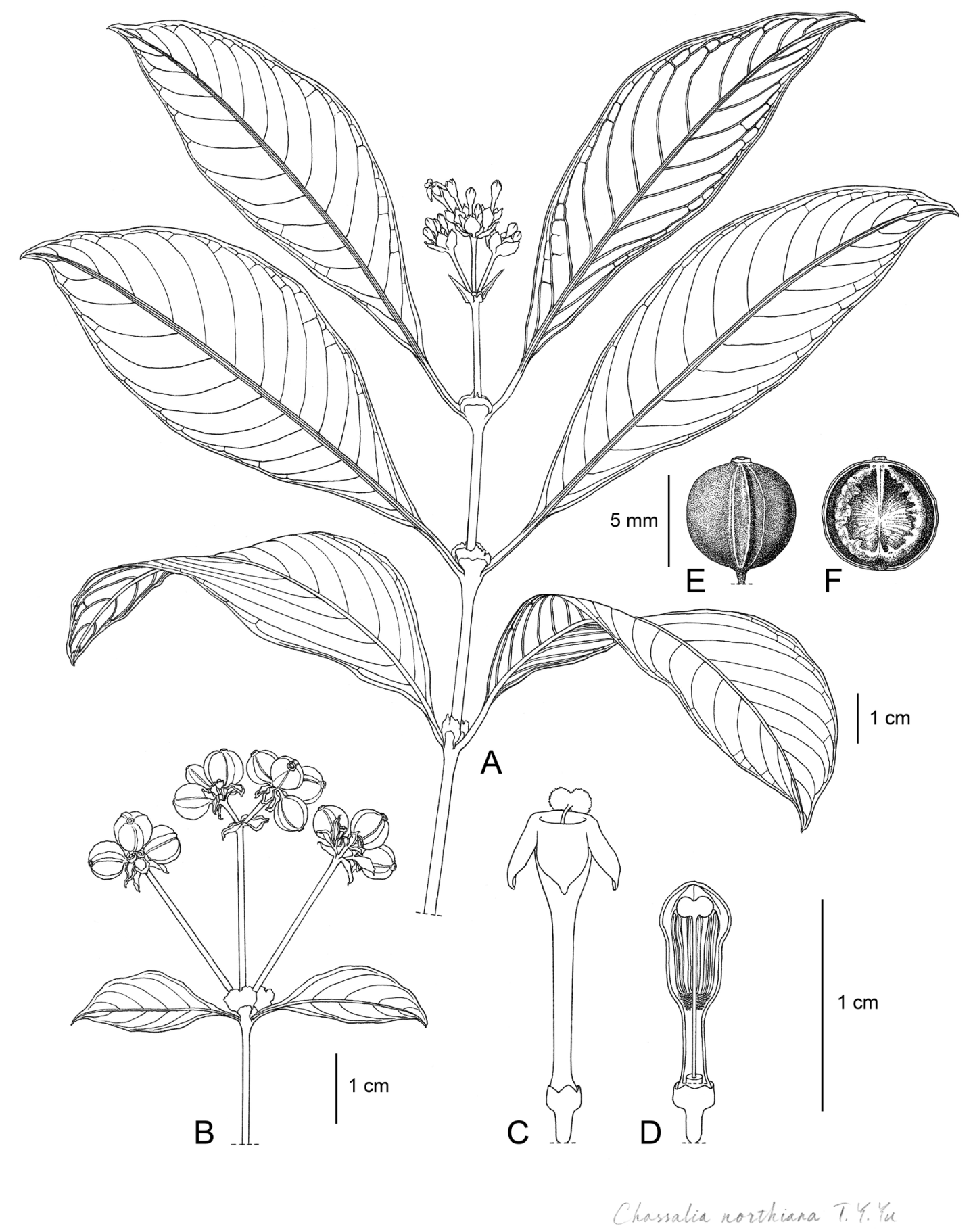

Fig. 28. Chassalia northiana T.Y.Yu sp. nov. A. Flowering shoot. B. Infructescences. C. Flower. D. Longitudinal view of corolla in bud showing stamens, band of hairs, stigma, style, disc, calyx and hypanthium. E. Dry fruit. F. Pyrene ventral surface. A, C-D from Bernard Lee Meng Hock S 53828; B, E-F from Munting \& Jugah S 55620. Drawn by T.Y. Yu. 


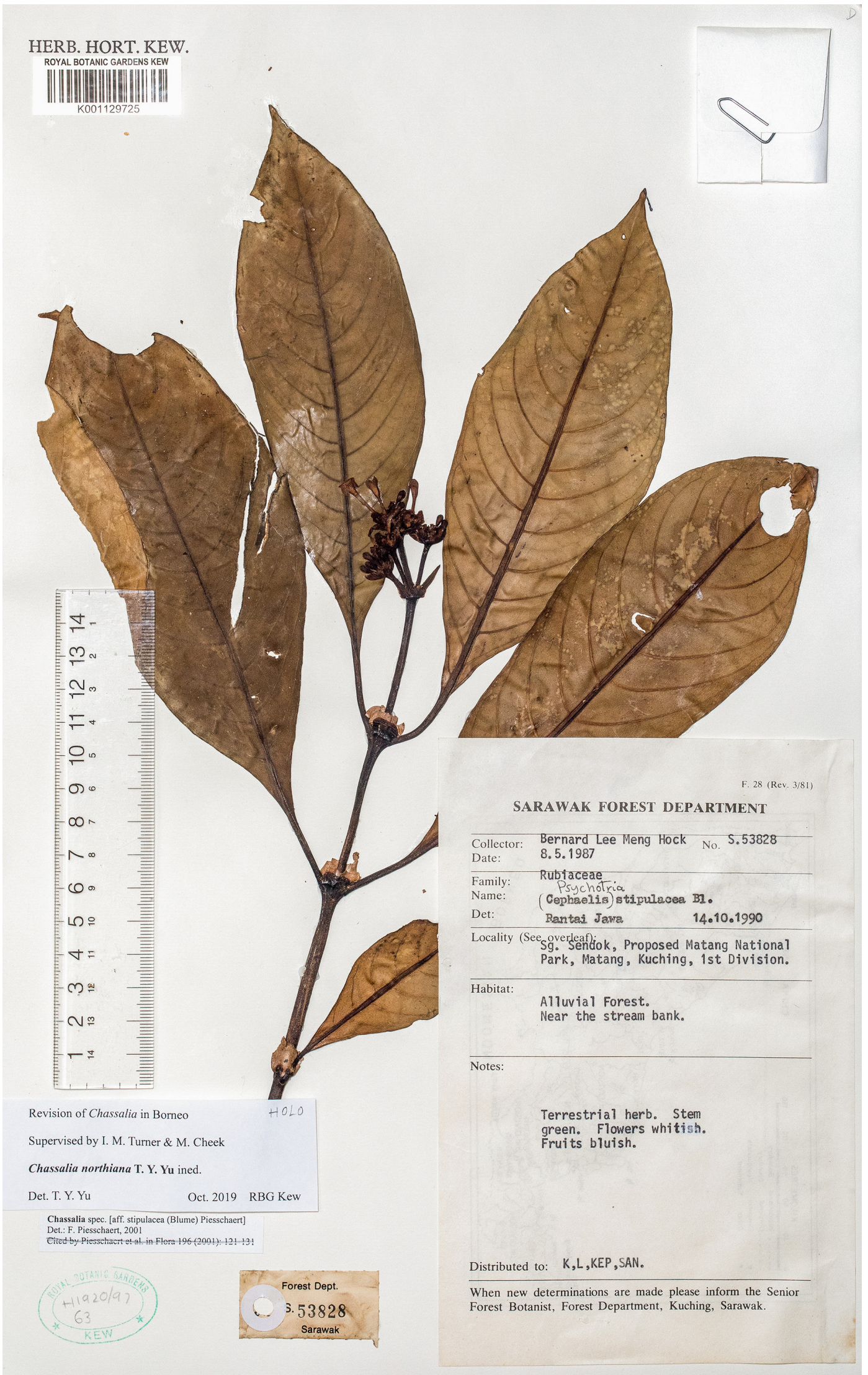

Fig. 29. Holotype of Chassalia northiana T.Y.Yu sp. nov. (Bernard Lee Meng Hock S 53828). 
sometimes growing larger than young but not fully developed leaves $3-7 \times 1.5-2 \mathrm{~cm}, 2$ stipule-like bracts 5-8 $\times 5-8 \mathrm{~mm}$, rachis and branches sometimes with second branches and second internode of rachis $2-10 \mathrm{~mm}$ long, capitular bracts $8-10 \times 2-5 \mathrm{~mm}$. Flowers sessile, $15-18 \mathrm{~mm}$ long, corolla tube lower part $0.6-1 \mathrm{~mm}$ wide, upper part 2-2.5 mm wide, mouth $3.5-4 \mathrm{~mm}$ wide, corolla lobes usually 5 , $3 \times 2.5 \mathrm{~mm}$, stamens $2.3-2.5 \mathrm{~mm}$ long, inserted $1 \mathrm{~mm}$ from corolla mouth, inside corolla tube a band of hairs $0.7 \mathrm{~mm}$ long at base of stamens, hairs erect, colourless, $0.1-0.2 \mathrm{~mm}$ long; stigma bilobed, each lobe round, $0.5 \mathrm{~mm}$ in diameter; disc $1.2 \times 1.2 \mathrm{~mm}$. Hypanthium $4 \times 2 \mathrm{~mm}$, calyx tube $1 \times 4 \mathrm{~mm}$ with 5 lobes $0.1 \times 0.5 \mathrm{~mm}$. Fruit black or deep brown when dry, blue when ripe, ellipsoid to round, $7 \times 6 \times$ $6 \mathrm{~mm}$, calyx persistent, not accrescent, $0.5 \times 2 \mathrm{~mm}$, disc persistent, not accrescent, $1.2 \times 1.2 \mathrm{~mm}$. Pyrene plano-convex, $7 \times 5.5-6 \times 2-3 \mathrm{~mm}$, dorsal surface convex, with two adjacent parallel longitudinal crests, $0.4 \mathrm{~mm}$ wide, $0.25 \mathrm{~mm}$ apart along their length, forming a longitudinal groove from apex to base between the two crests; ventral surface concave, central part slightly elevated, margin with an endocarpal outgrowth $1 \mathrm{~mm}$ wide, with a groove between the edge of endocarp and endocarpal outgrowth $0.5 \mathrm{~mm}$ wide; raphal opening at base of the endocarpal outgrowth, round, $0.4 \mathrm{~mm}$ wide, $0.2-0.3 \mathrm{~mm}$ from the edge of the pyrene wall, apex with a bony spine, spine triangular, erect, $0.8 \times 0.2 \mathrm{~mm}$. PGS not detected. Seed light brown, hemi-ellipsoid, $5 \times 6 \mathrm{~mm}$, longitudinally slightly crested at midline of dorsal surface, endosperm not detected.

\section{Distribution, habitat}

Borneo: Malaysia, from central Sabah to west Sarawak. Alluvial forest, stream banks, Kerangas forest. Lowland to montane forest, alt. $200-1000 \mathrm{~m}$.

\section{Remarks}

This species is one of the most widespread of the Bornean 'involucrate' species.

Chassalia psychotriformis I.M.Turner nom. nov.

Replaced synonym:

Cephaelis psychotrioides Valeton, Icones Bogorienses 4 (3): t. 357 (Valeton 1913b). - Chassalia psychotrioides (Valeton) I.M.Turner, Feddes Repertorium 139: 399 (Turner 2019), nom. illegit., non Chassalia psychotrioides DC., Prodromus Systematis Naturalis Regni Vegetabilis 4: 531 (1830) (Candolle 1830). - Type: INDONESIA • Borneo, Liang Gagang; 1893-1894; Hallier 2703; hololectotype: BO[BO-1374040], designated by Turner (2019:399); isolectotype: BO[BO-1374039].

\section{Additional material}

MALAYSIA - Borneo, Sarawak • Serian, Gunong Penrissen; 2 May 1962; Ilias Paie S 16336; K!, L, SAR - Serian, Tebedu, Bukit Simurus; 12 Feb. 1985; Abg. Mohtar S 49281; K!, SAR $-2^{\text {nd }}$ Division, Lubok Antu District, Lanjak-Entimau P.F., Sg. Jelok, near Bukit engkajang; 18 Mar. 1974; Paul Chai $S$ 34024; K!, L, KEP, MO, SAN, SAR •

INDONESIA - Borneo, Jaro Dsm, 10 km NE of Muara Uya, Kalimantan Selatan; alt. 90 m; 16 Nov. 1971; Kuswata Kartawinata 828; K!, L.

\section{Description}

Shrub to small tree, 1-1.5 m tall. Stem terete, central part slightly canaliculate when dry, hairy from the first or second internode from apex. Internodes $1.5-8 \mathrm{~cm} \times 4 \mathrm{~mm}$. Leaf-blades obovate to elliptic, $20.5-28.5 \times 5.5-8 \mathrm{~cm}$, apex acute to acuminate, base truncate, adaxial surface glabrous, abaxial surface hairy, midrib slightly raised on both sides, densely hairy abaxially, petiole $2-5.5 \mathrm{~cm}$ long, young petiole hairy, glabrescent. Stipule flabellate, apex usually broken, 3-8 $\times 5-10 \mathrm{~mm}$, slightly hairy when young. 
Inflorescence a compound cyme, $7 \mathrm{~cm}$ long, all parts hairy except fruits; peduncle $4 \mathrm{~cm}$ long, bracts of peduncle stipule-like, $1 \times 5 \mathrm{~mm}$, first branches and first internode of rachis 2-2.5 cm long, bracts of first branches and first internode of rachis 2, 4-6 $\times 1-2 \mathrm{~mm}$, second branches and second internode of rachis $3.1 \mathrm{~cm}$ long, bracts of second branches and second internode of rachis 2 , slightly smaller than bract of first branches and first internode of rachis, $2 \times 2 \mathrm{~mm}$, bracts of capitulum 2-3 $32 \mathrm{~mm}$. Flowers not seen. Fruits $8-10 \times 4-9 \times 4-6 \mathrm{~mm}$, blackish brown when dry, calyx persistent, not accrescent, $0.4 \times 2 \mathrm{~mm}$, disc persistent, not accrescent, $0.5 \times 1 \mathrm{~mm}$. Pyrenes plano-convex, 8-9 8 4-9 $\times 4-6 \mathrm{~mm}$, dorsal surface convex, with two adjacent parallel longitudinal crests, $0.5 \mathrm{~mm}$ wide, $0.25 \mathrm{~mm}$ apart along their length, forming a longitudinal groove from apex to base between the two crests; ventral surface concave, central part slightly elevated, margin with an endocarpal outgrowth $1-1.2 \mathrm{~mm}$ wide, with a groove between the edge of endocarp and endocarpal outgrowth $0.5 \mathrm{~mm}$ wide. Raphal opening, bony spine, PGS, seed and endosperm not detected.

\section{Distribution}

Borneo: West Kalimantan, Bukit Liang; Sarawak, First Division, Serian, Gunung Penrissen.

\section{Remarks}

Turner (2019) transferred Cephaelis psychotrioides Valeton to Chassalia. The resultant new combination was illegitimate, being a later homonym of Chassalia psychotrioides DC., a species from Mauritius. Therefore a nomen novum is here published for Valeton's name for the Bornean species.

Valeton's type specimen Hallier 2703 (BO-1374040) has a hairy infructescence. Additional information provided by the drawing included in the original publication of this species also shows that it has hairy petioles and abaxial leaf midribs (Valeton 1913b). The species differs from other Asian species of Chassalia by having a hairy petiole, lower midrib and secondary nerves of the leaves, also the stem apices and inflorescences are densely pubescent.

Chassalia psychotriformis is restricted to a region straddling the Sarawak-Kalimantan border in Borneo based on specimen records from $\mathrm{K}$ and other herbaria. The most distinctive vegetative character of C. psychotriformis is the pubescent abaxial surface of the leaves and the pubescent peduncles. It is the only species that has been found with a hairy peduncle among all Asian species of Chassalia. Therefore, the identification of C. psychotriformis is not difficult compared to that of most other Bornean species of Chassalia.

Chassalia ramosa T.Y.Yu sp. nov. urn:lsid:ipni.org:names:77215415-1

Figs $30-31$

\section{Diagnosis}

Differs from other Bornean species of Chassalia by the stems usually dividing terminally into two flowering branches, also in the highly contracted inflorescence rachis and first branches which are less than $0.5 \mathrm{~mm}$ long or less, each inflorescence comprising a single capitulum.

\section{Etymology}

The epithet reflects the high level of branching in this species, making its gestalt distinctive compared with other species of Chassalia in Borneo. 


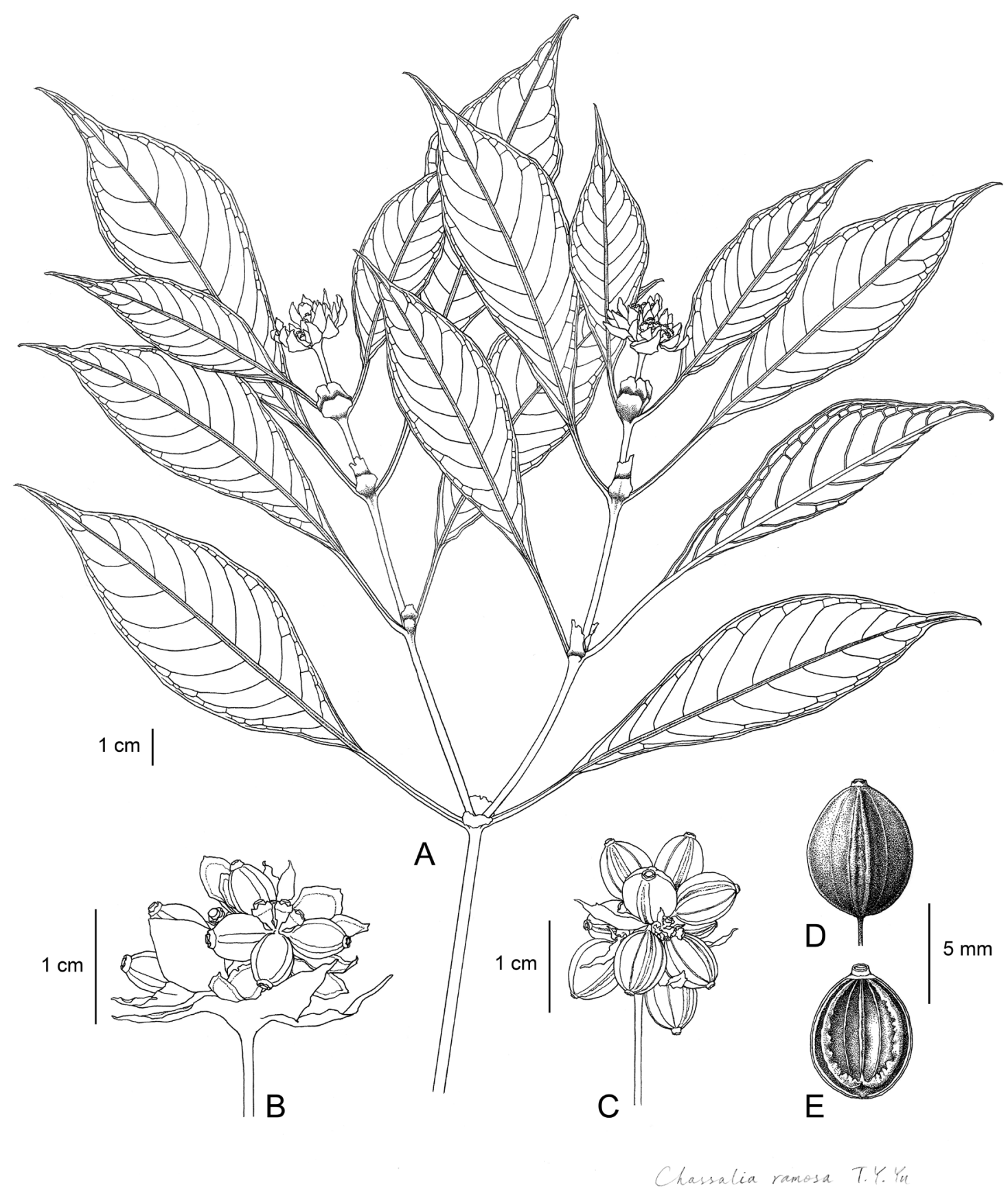

Fig. 30. Chassalia ramosa T.Y.Yu sp. nov. A. Flowering shoot. B. Infructescence with young fruit. C. Infructescence with ripe fruit. D. Dry fruit. E. Pyrene ventral surface. A-B from John H. Beaman 11533; C-E from John H. Beaman 11400. Drawn by T.Y. Yu. 


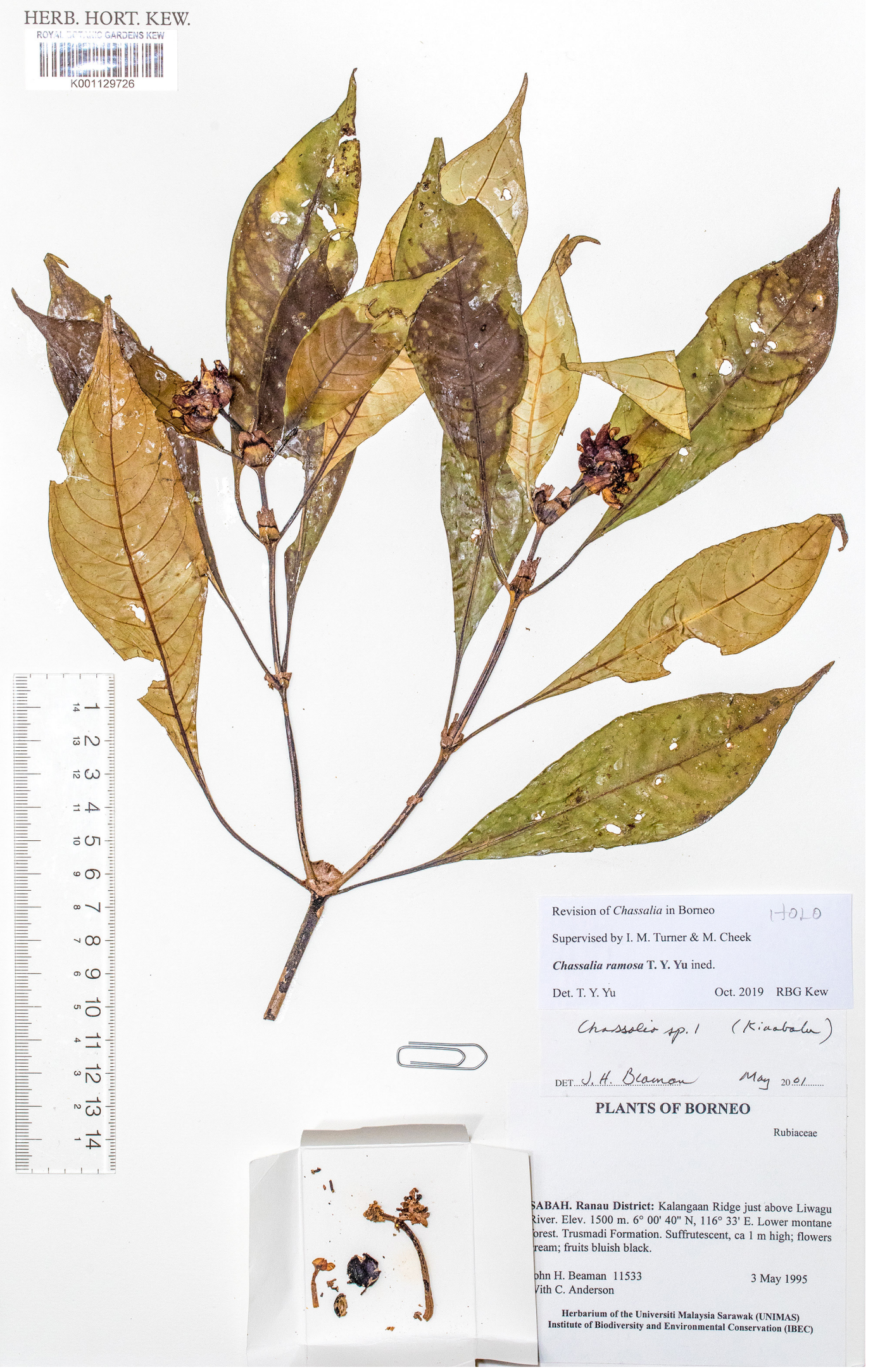

Fig. 31. Holotype of Chassalia ramosa T.Y.Yu sp. nov. (John H. Beaman 11533). 
Type

MALAYSIA - Borneo, Sabah • Ranau District, Kalangaan Ridge just above Liwagu River; $6^{\circ} 00^{\prime} 40^{\prime \prime} \mathrm{N}$, 116³3'00" E; alt. 1500 m; 3 May 1995; John H. Beaman 11533; holotype: K[K001129726]!; isotypes: UNIMAS, IBEC.

\section{Additional material}

MALAYSIA - Borneo, Sabah • Ranau District, Taman Kinabalu, side of Silau trail; 17 Jan. 1987; Amin et al. SAN 117332; K!, SAN - Mount Kinabalu, Bukit Burung Trail near Park Headquarters; $6^{\circ} 00^{\prime}$ N, 116²32' E; alt. 1500 m; 3 May 1995; Teofila E. Beaman 252; K!, UNIMAS, IBEC - Mount Kinabalu, lower Siau-silau trail near Park Headquarters; 600'30" N, 116³2'40" E; alt. 1500 m; 24 Mar. 1995; John H. Beaman 11400; K!, UNIMAS, IBEC • Tambunan District, Crocker Range, Km 59.5 on Kota Kinabalu-Tanbunan Road; $5^{\circ} 06^{\prime} \mathrm{N}, 116^{\circ} 21^{\prime} \mathrm{W}$; alt. 1400 m; John H. Beaman 7343; K!, MSC, UKMS.

\section{Description}

Shrub, 1-1.5 m tall, glabrous. Stems terete, slightly hollowed or not hollowed, usually bifurcating terminally, with each branch producing an inflorescence, internodes on old branches $3-5 \mathrm{~cm}$, internode on flowering shoot $1-6.5 \mathrm{~cm} \times 1-2.5 \mathrm{~mm}$, sometimes slightly canaliculate. Leaf-blades elliptic to oblanceolate, $10-15 \times 3-4.5 \mathrm{~cm}$, apex acuminate, acumen $1.5-2 \mathrm{~cm}$, base truncate; midrib slightly raised from both adaxial and abaxial, secondary nerves 10-12 on each side of the midrib, petiole $1-4 \mathrm{~cm}$ long. Stipule flabellate, old stipules $1 \times 0.6-1 \mathrm{~cm}$. Inflorescence terminal, capitula condensed into one head, peduncle $1.5-3 \mathrm{~cm}$, rachis and first branches less than $0.5 \mathrm{~mm}$ or absent, bracts of rachis and first branches 2, elliptic to narrowly lanceolate, $13-18 \times 1-1.5(-5) \mathrm{mm}$, bracts of each capitulum lanceolate, $10 \times 3-5 \mathrm{~mm}$. Flower not seen. Fruits dark green to bluish black, 5-7 in each capitulum, ellipsoid, 6-7 $\times$ 5.5-6 $\times 4.5-5 \mathrm{~mm}$, pedicel $3 \times 0.5 \mathrm{~mm}$, calyx persistent, not accrescent, $0.5 \times 1.3 \mathrm{~mm}$, disc persistent, not accrescent, $0.2 \times 0.6 \mathrm{~mm}$. Pyrene plano-convex, $6-7 \times 5.5-6 \times 2.5-3 \mathrm{~mm}$, dorsal surface convex, with two adjacent parallel longitudinal crests, $0.3 \mathrm{~mm}$ wide, $0.2 \mathrm{~mm}$ apart along their length, forming a longitudinal groove from apex to base between the two crests; ventral surface concave, central part slightly elevated, margin with an endocarpal outgrowth $0.4-0.5 \mathrm{~mm}$ wide, with a groove between the edge of endocarp and endocarpal outgrowth $0.1 \mathrm{~mm}$ wide; raphal opening at base of the endocarpal outgrowth, round, $0.4 \mathrm{~mm}$ wide, $0.3 \mathrm{~mm}$ from the edge of the pyrene wall, apex with a bony spine, spine triangular, erect, $1 \times 0.1 \mathrm{~mm}$. PGS not detected. Seed not detected.

\section{Distribution, habitat}

Borneo: Malaysia, Ranau District and Tambunan District, around Mount Kinabalu, Crocker Formation and Trusmadi Formation; lower montane forest, at 1400-1500 m a.s.1.

\section{Discussion}

Species of Chassalia can be distinguished from those of other genera of Rubiaceae by having partly or completely corky (chaffy) stipules (note that the stipules of lower nodes are usually damaged) and pyrenes which are usually excavated ventrally. The stipules usually soon develop a brown chaffy apex, with the basal region remaining green and membranous or leathery. As the stipule gets older, the chaffy part usually extends further towards the base of the stipule, and eventually the entire stipule becomes chaffy.

\section{Group 1. Chassalia curviflora}

The most widespread species of Chassalia in Asia, C. curviflora, shares some distinctive characters with African and Madagascan species, such as the corolla tube relatively long and usually curved and winged in bud, the bract of the peduncles and partial peduncles usually small or absent, infructescence axes 
usually becoming succulent with vivid colour, pyrene dorsal surface with only one longitudinal crest or dorsal crest absent. It is the only Bornean species with these characteristics.

\section{Group 2. Chassalia javanica}

Chassalia javanica is another very distinctive species among all Bornean, indeed all Asian species of Chassalia. It was formerly placed in the genus Proscephaleium Korth. as the only species in this genus. Chassalia javanica was transferred to Chassalia (Piesschaert et al. 2001), however, the authors failed to validate the combination. The new combination Chassalia javanica was subsequently published (Turner 2019). This is the only known epiphytic species of Chassalia recorded in Asia. Apart from the habit, the pyrene structure of Chassalia javanica is also different from other Asian species. The pyrene dorsal surface of this species is more similar to some African species which have grooved type pyrenes, by having relatively wide endocarp outgrowths and a relatively pronounced ventral central crest (Piesschaert et al. 2001). The median part between the two endocarp outgrowths is slightly excavated, while the central crest reaches almost as high as the plane of the endocarp outgrowth.

\section{Group 3. Chassalia 'involucrate' species}

However, most of the species in Borneo and the Malay Peninsula are different from C. curviflora and from $C$. javanica. The vast majority of the specimens from Borneo that were studied have stipules seldom and then only slightly bilobed, straight corolla tubes broadening conspicuously near the apex but not curved to one side (not zygomorphic), infructescence axes usually not becoming succulent, and pyrene dorsal surfaces with two adjacent longitudinal crests. This group of species usually have a capitulum with small to large capitular bracts, outer bracts usually larger than inner bracts and sometimes covering the flower buds. Therefore, in this study, a new informal name, the 'Involucrate group' has been given to this group of species.

The pyrene structures of 'involucrate' species are relatively consistent. In this group, species usually have a pyrene dorsal surface with two adjacent longitudinal crests. Between these two crests, there is usually a visible longitudinal groove. On the ventral surface of the pyrene, these species have two endocarp outgrowths along the margins, with a ventral excavation between them. A groove is located at the proximal margin of the pyrene dorsal surface and the endocarp outgrowth, and at the base of this groove, there is a raphal opening with a bony spine at the apex. It is hard to find the preformed germination slits (PGS) (Robbrecht 1988), usually associated with Chassalia, among any of the 'involucrate' species, but the pyrenes of some species can be easily separated into two halves from the base of the groove between the dorsal surface margin and the endocarp outgrowth. This may represent an unusual variant of preformed germination slit.

The 'Involucrate species group' appears to be a Sunda shelf taxon found on the Malay Peninsula, Sumatra, Java and Borneo, apparently with maximum species diversity on Borneo.

Within Borneo, 'involucrate' species of Chassalia diversity appears to be concentrated in the northern third, which corresponds politically mainly with Malaysian Borneo, that is the north and north-east. This apparent diversity is probably enhanced by more collecting on the Malaysian side and also better availability to us of specimens from Sabah, Sarawak and Brunei. However, the first described species of the endemic Bornean 'involucrate' species, Chassalia psychotriformis, was described as Cephaelis psychotrioides from Indonesian Borneo near the border with Sarawak, source of the majority of specimens of that species. We did not have direct physical access to the Chassalia material from L or BO, but only electronic images, so Indonesian Bornean (Kalimantan) collections are probably underrepresented in our study. However, unless there are some very misplaced taxa, we have covered all the published names for Bornean Chassalia. 


\section{Centres of diversity of 'involucrate' Bornean species}

While Chassalia northiana sp. nov. and C. involucrata sp. nov. are widespread from West to East of Borneo, most 'involucrate' species are confined to small areas. There are two main clusters of endemics which correspond with those identified for other plant groups (Ashton 2014):

The Kuching-Matang area in western Borneo, in extreme western Malaysian Sarawak, with some records in neighbouring Indonesian Borneo: C. lancifolia sp. nov., C. lancifolioides sp. nov. and C. macrocarpa sp. nov.

The Mt Kinabalu area in Malaysian Sabah, including Ranau: C. beamanii sp. nov., C. chewii sp. nov., C. kinabaluensis sp. nov., C. longipes sp. nov. and C. ramosa sp. nov.

Other narrow endemics occur in Malaysian Sarawak: Gunung Mulu (C. muluensis sp. nov.), G. ApingG. Gaharu (C. muscicola sp. nov.); G. Bangai, G. Goram, G. Lanjak (C. atropurpurea sp. nov.) and from two locations in Malaysian Sabah near Mt Kinabalu (C. calamus sp. nov.).

\section{Suggestions for further research}

This study is mainly based on specimens from the herbarium of the Royal Botanic Gardens, Kew (K) and those loaned from the herbaria of Singapore Botanic Garden (SING) and the Forest Research Institute, Malaysia (KEP). The specimens that have been studied are mostly from Malaysian Borneo. Very few of the physical specimens studied (as opposed to digital images) are from Indonesian Borneo, so further work based on specimens of the Naturalis (L) and herbaria in Indonesia (principally BO) is needed for a more complete study of Bornean Chassalia. In this study much progress has been made resolving species limits in Bornean material attributed to Chassalia. It would be logical and beneficial to continue this work for other parts of Southeast Asia where the genus has been similarly neglected, such as Sumatra. Molecular phylogenetic work would be valuable to resolve the evolutionary relationships of the different species of Chassalia groups identified in this study and, if samples of other genera of the tribe were included, would inform a revised classification of Chassalia which is evidently needed.

\section{Acknowledgements}

We thank the herbarium curators of KEP, SING and K for access to the herbarium specimens upon which this paper is based. Without their work in maintaining, retrieving and dispatching the specimens with diligence and care, and without their permission to rehydrate fruits and flowers for dissection, measurement and photography, this paper would not have been possible. We also thank the many persons from around the world who collected these specimens, recorded data, and placed them in herbaria so that they could be preserved for posterity. Some of these we have commemorated through naming species in their honour: Chew Wee Lek, Marianne North, John Beaman, but the efforts of all are greatly appreciated.

\section{References}

Ashton P.S. 2014. On the Forests of Tropical Asia: Lest the Memory Fade. Kew Publishing, Kew, London.

Beaman J.H. \& Anderson C.E. 2004. The Plants of Mount Kinabalu 5. Dicotyledon Families Magnoliaceae to Winteraceae. Natural History Publications (Borneo), Kota Kinabalu.

Blume C.L. 1823. Catalogus van eenige der merkwaardigste zoo in-als uit-heemsche gewassen, te vinden in 's Lands Plantentuin te Buitenzorg opgemaakt door C. L. Blume, M.D., Directeur van voorz. tuin. Batavia [Jakarta].

Blume C.L. 1826-1827. Bijdragen tot de Flora van Nederlandsch Indië. Vol. 16. Ter Lands Drukkerij, Batavia [Jakarta]. 
Bremekamp C.E.B. 1962. Revision des Chasallia de Madagascar. Candollea 18: 195-238.

Candolle A.P. de 1830. Prodromus Systematis Naturalis Regni Vegetabilis. Vol. 4. Sumptibus Sociorum Treuttel et Würtz, Paris. https://doi.org/10.5962/bhl.title.286

Cheek M. \& Csiba L. 2000. A new species and new combination in Chassalia (Rubiaceae) of western Cameroon. Kew Bulletin 55: 883-888. https://doi.org/10.2307/4113633

Cheek M., Pollard B.J., Darbyshire I., Onana J.-M. \& Wild C. 2004. The Plants of Kupe, Mwanenguba and the Bakossi Mts, Cameroon. A Conservation Checklist. Royal Botanic Gardens, Kew, London.

Craib W.G. 1931. Contributions to the Flora of Siam. Additamentum XXXI. Bulletin of Miscellaneous Information, Kew 1931: 275-280. https://doi.org/10.2307/4102489

Davis A.P., Forman L.L., Ridsdale C.E. \& Wong K.M. 1996. Rubiaceae. In: Coode M.J.E., Dransfield J., Forman L.L., Kirkup D.W. \& Said I.M. (eds) A Checklist of the Flowering Plants and Gymnosperms of Brunei Darussalam: 263-299. Ministry of Industry and Primary Resources, Bandar Seri Begawan.

Davis A.P., Govaerts R., Bridson D.M., Ruhsam M., Moat J. \& Brummitt N.A. 2009. A global assessment of distribution, diversity, endemism, and taxonomic effort in the Rubiaceae. Annals of the Missouri Botanical Garden 96: 68-78. https://doi.org/10.3417/2006205

Deb D.B. \& Krishna B. 1983 ['1982']. Taxonomic studies of the genus Chassalia Comm. ex Poir. in India and adjoining regions. Bulletin of the Botanical Survey of India 24: 221-224.

Hochreutiner B.-P.-G. 1934. Plantae hochreutineranae. Fascicule III. Candollea 5: 175-341.

IPNI. continuously updated. The International Plant Names Index. Available from http://www.ipni.org [accessed 4 Feb. 2021].

Korthals P.W. 1851. Overzigt der Rubiaceën van de Nederlandsch-Oostindische Kolonien. Nederlandsch Kruidkundige Archief 2 (2): 145-269.

Kuntze O. 1891a. Revisio Generum Plantarum. Pars II. Arthur Felix, Leipzig.

Kuntze O. 1891b. Revisio Generum Plantarum. Pars I. Arthur Felix, Leipzig.

Merrill E.D. 1921. A bibliographic enumeration of Bornean plants. Journal of the Straits Branch of the Royal Asiatic Society, Special Number: 1-637. https://doi.org/10.5962/bhl.title.28790

Miquel F.A.W. 1857. Flora van Nederlandsch Indië. Vol. II, Part 2. C.G. van der Post, Amsterdam.

Piesschaert F., Robbrecht E. \& Smets E. 2001. Patterns in pyrenes: the systematic significance of pyrene morphology in Chassalia (Rubiaceae-Psychotrieae) and related genera. Flora 196: 121-131. https://doi.org/10.1016/S0367-2530(17)30027-0

Razafimandimbison S.G., Rydin C. \& Bremer B. 2008. Evolution and trends in the Psychotrieae alliance (Rubiaceae) - a rarely reported evolutionary change of many-seeded carpels from one-seeded carpels. Molecular Phylogenetics and Evolution 48 (1): 207-223. https://doi.org/10.1016/j.ympev.2008.03.034

Razafimandimbison S.G., Taylor C.M., Wikstrom N., Pailler T., Khodabandeh A. \& Bremer B. 2014. Phylogeny and generic limits in the sister tribes Psychotrieae and Palicoureeae (Rubiaceae): evolution of schizocarps in Psychotria and origins of bacterial leaf nodules of the Malagasy species. American Journal of Botany 101: 1102-1126. https://doi.org/10.3732/ajb.1400076

Robbrecht E. 1988. Tropical woody Rubiaceae: characteristic features and progressions: contributions to a new subfamilial classification. Opera Botanica Belgica 1: 1-271.

Robbrecht E. \& Manen J.-F. 2006. The major evolutionary lineages of the coffee family (Rubiaceae, angiosperms). Combined analysis (nDNA and cpDNA) to infer the position of Coptosapelta and Luculia, and supertree construction based on $r b c L, r p s 16, \operatorname{trnL-trnF}$ and $a t p B-r b c L$ data. A new classification in two subfamilies Cinchonoideae and Rubioideae. Systematics and Geography of Plants 76: 85-146. Available from https://www.jstor.org/stable/20649700 [accessed 23 Feb. 2021]. 
Roxburgh W. 1824. Flora indica. Vol. II. Mission Press, Serampore.

Ruhsam M., Govaerts R. \& Davis A.P. 2008. Nomenclatural changes in preparation for a World Rubiaceae Checklist. Botanical Journal of the Linnean Society 157: 115-124. https://doi.org/10.1111/j.1095-8339.2008.00779.x

Schumann K. 1891. Rubiaceae. In: Engler A. \& Prantl K. (eds) Die natürlichen Pflanzenfamilien 4 (45): 1-156. Verlag von Wilhelm Engelmann, Leipzig.

Sonké B., Nguembou C.K., Cheek M. \& Davis A.P. 2007. A new species of Chassalia (Rubiaceae, Rubioideae) from southern Cameroon: C. bipindensis. Kew Bulletin. 61: 585-589. Available from http://www.jstor.org/stable/20443302 [accessed 4 Feb. 2021].

Taylor C.M., Razafimandimbison S.G. Barrabe L., Jardim J.G. \& Barbosa M.R.V. 2017. Eumachia expanded, a pantropical genus distinct from Psychotria (Rubiaceae, Palicoureeae). Candollea 72: 289319. https://doi.org/10.15553/c2017v722a6

Thiers B. continuously updated. Index Herbariorum: A Global Directory of Public Herbaria and Associated Staff. New York Botanical Garden's Virtual Herbarium. Available from http://sweetgum.nybg.org/science/ih/ [accessed 3 Apr. 2020].

Thwaites G.H.K. 1859. Enumeratio Plantarum Zeylaniae. Part 2. Dulau, London.

Turland N.J., Wiersema J.H., Barrie F.R., Greuter W., Hawksworth D.L., Herendeen P.S., Knapp S., Kusber W.-H., Li D.-Z., Marhold K., May T.W., McNeill J., Monro A.M., Prado J., Price M.J. \& Smith G.F. (eds.) 2018. International Code of Nomenclature for algae, fungi, and plants (Shenzhen Code) adopted by the Nineteenth International Botanical Congress, Shenzhen, China, July 2017. Regnum Vegetabile 159: 1-254. https://doi.org/10.12705/Code.2018

Turner I.M. 2019. A nomenclatural synopsis of Chassalia (Rubiaceae) in Asia. Feddes Repertorium 130: 396-404. https://doi.org/10.1002/fedr.201900002

Valeton T. 1913a. Tabula CCCXXXVI. Cephaelis stipulacea Bl. In: Icones Bogorienses, Vol. IV, Fascicle 3: 115-118. E.J. Brill, Leiden.

Valeton T. 1913b. Tabula CCCLVII. Cephaelis psychotrioides Val. In: Icones Bogorienses, Vol. IV, Fascicle 3: 185-186. E.J. Brill, Leiden.

Verdcourt B. 1976. Flora of Tropical East Africa. Rubiaceae (Part 1). Crown Agents for Oversea Governments and Administrations, London.

Wong K.M. \& Puff C. 1993. A synopsis of the genera of Rubiaceae in Borneo. Sandakania 2: 13-34.

Manuscript received: 22 July 2020

Manuscript accepted: 26 November 2020

Published on: 9 March 2021

Topic editor: Frederik Leliaert

Desk editor: Radka Rosenbaumová

Printed versions of all papers are also deposited in the libraries of the institutes that are members of the EJT consortium: Muséum national d'histoire naturelle, Paris, France; Meise Botanic Garden, Belgium; Royal Museum for Central Africa, Tervuren, Belgium; Royal Belgian Institute of Natural Sciences, Brussels, Belgium; Natural History Museum of Denmark, Copenhagen, Denmark; Naturalis Biodiversity Center, Leiden, the Netherlands; Museo Nacional de Ciencias Naturales-CSIC, Madrid, Spain; Real Jardín Botánico de Madrid CSIC, Spain; Zoological Research Museum Alexander Koenig, Bonn, Germany; National Museum, Prague, Czech Republic. 